Prepared in cooperation with the City of Prescott, the Town of Prescott Valley, and the Salt River Project

\title{
Geochemical Assessment of Groundwater in the Big Chino Subbasin, Arizona, 2011-18
}
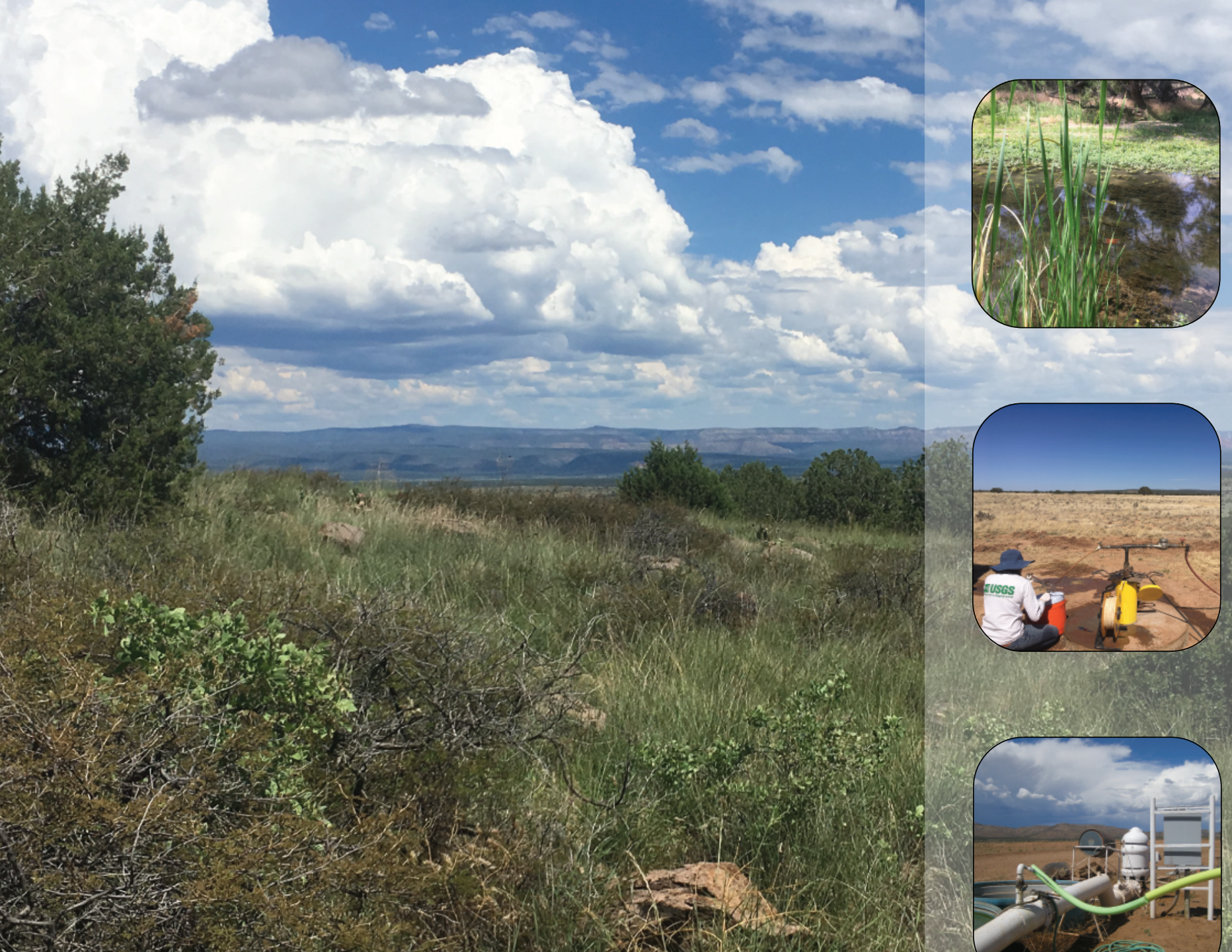

Scientific Investigations Report 2020 5094

U.S Department of the interior U.S.Geological Suyey 
Cover. A (Background image), Big Chino basin west of State Highway 89 and north of Paulden, Arizona. Photograph by Kimberly Beisner, U.S. Geological Survey (USGS). B (Top inset), Verde River downstream of confluence with Granite Creek. Photograph by Kimberly Beisner, USGS. C (Middle inset), Sampling well B-18-01 19ADC1. Photograph by Edyth Hermosillo, USGS. D (Bottom inset), Sampling well B-19-04 10AAC. Photograph by Nicholas Paretti, USGS. 


\section{Geochemical Assessment of Groundwater in the Big Chino Subbasin, Arizona, 2011-18}

By Kimberly R. Beisner and Casey J.R. Jones

Prepared in cooperation with the City of Prescott, the Town of Prescott Valley, and the Salt River Project

Scientific Investigations Report 2020-5094 


\title{
U.S. Department of the Interior \\ DAVID BERNHARDT, Secretary
}

\author{
U.S. Geological Survey \\ James F. Reilly II, Director
}

U.S. Geological Survey, Reston, Virginia: 2020

For more information on the USGS - the Federal source for science about the Earth, its natural and living resources, natural hazards, and the environment-visit https://www.usgs.gov or call 1-888-ASK-USGS.

For an overview of USGS information products, including maps, imagery, and publications, visit https://store.usgs.gov/.

Any use of trade, firm, or product names is for descriptive purposes only and does not imply endorsement by the U.S. Government.

Although this information product, for the most part, is in the public domain, it also may contain copyrighted materials as noted in the text. Permission to reproduce copyrighted items must be secured from the copyright owner.

Suggested citation:

Beisner, K.R., and Jones, C.J.R., 2020, Geochemical assessment of groundwater in the Big Chino subbasin, Arizona, 2011-18: U.S. Geological Survey Scientific Investigations Report 2020-5094, 49 p., https://doi.org/10.3133/ sir20205094.

Associated data for this publication:

Beisner, K.R., and Jones, C.J., 2019, Water quality parameters in the Verde River below Granite Creek June 2018, U.S. Geological Survey data release, https://doi.org/10.5066/P909LD47.

Beisner, K.R., Tucci, R., and Jones, C.J., 2019, Carbon and strontium isotopic data for rock, soil, and soil gas from the Big Chino sub-basin, Arizona: U.S. Geological Survey data release, https://doi.org/10.5066/P9HMZNIK.

ISSN 2328-0328 (online) 


\section{Acknowledgments}

Various landowners graciously allowed us to sample their groundwater wells. Southwest Groundwater Consultants (Matrix New World) provided valuable coordination to sample newly installed observation wells in 2018. Nick Paretti, Edyth Hermosillo, and Rachel Tucci from the U.S. Geological Survey provided valuable help collecting groundwater samples for this study. 



\section{Contents}

Acknowledgments ……...................................................................................................................

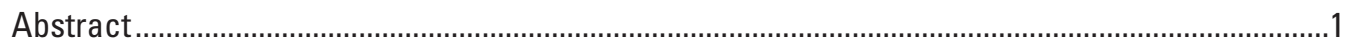

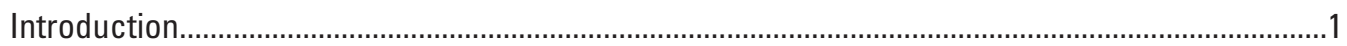

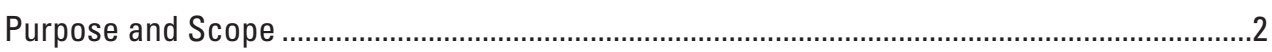

Study Area

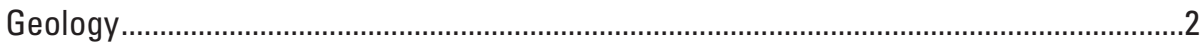

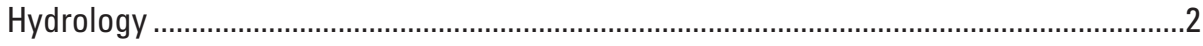

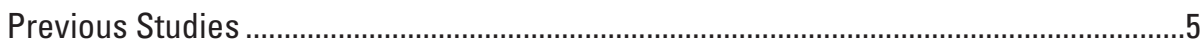

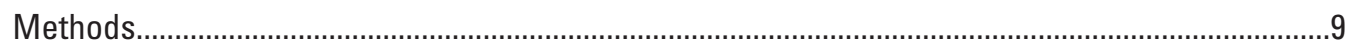

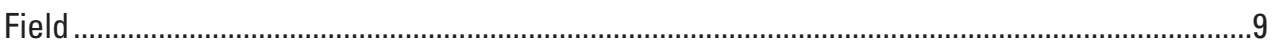

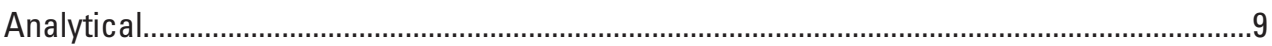

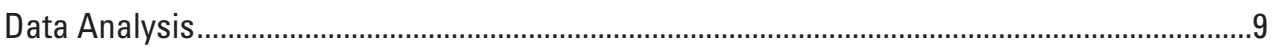

Geochemical Analysis of Water Resources in the Big Chino Subbasin........................................14

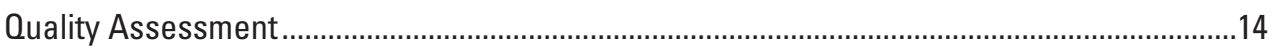

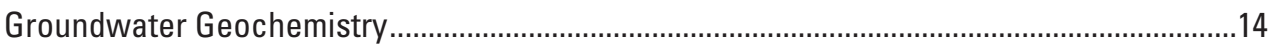

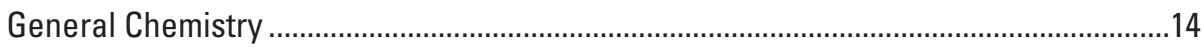

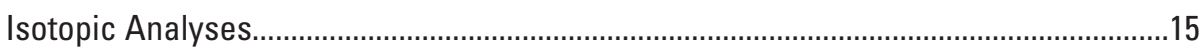

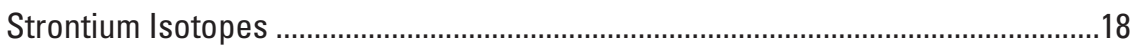

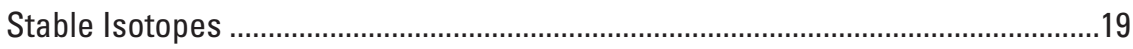

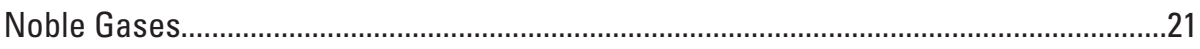

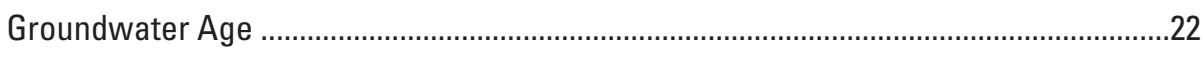

Multivariate Analysis..............................................................................................30

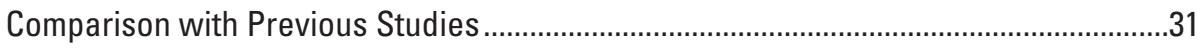

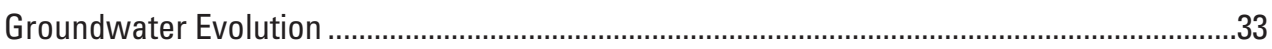

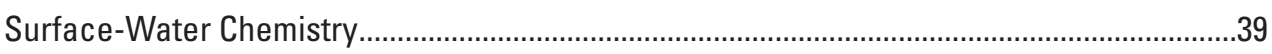

Spatial Variation of Water-Quality Properties in Verde River Below Granite Creek ......39

General Water Chemistry at Verde River Near Paulden ....................................................39

Analysis of Stable Isotopes of Surface Water ................................................................40

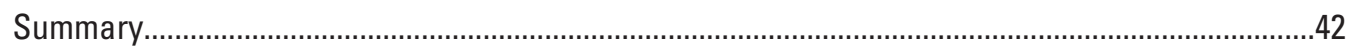

References Cited..............................................................................................................4

Appendix 1. Groundwater Geochemistry Data for Samples Collected by the U.S.

Geological Survey from the Big Chino Subbasin Between 2011 and 2018 ........................49

\section{Figures}

1. Map showing Big Chino subbasin study area and features mentioned in this report......3

2. Geologic stratigraphic section from Big Chino subbasin study area ................................4

3. Map showing geology of the Big Chino subbasin study area .........................................

4. Map showing groundwater and surface-water sampling locations and surface-water features in the Big Chino subbasin study area ...........................................

5. Map showing geologic setting along a gaining reach near the headwaters of the Verde River ...................................................................................................

6. Boxplots of selected water chemistry properties, categorized by source .......................17 
7. Trilinear diagram showing major ion composition of groundwater samples ...................18

8. Boxplot of fluoride concentrations, categorized by source .........................................19

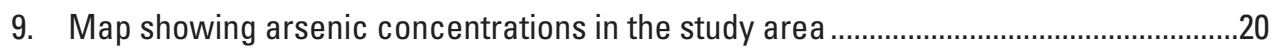

10. Boxplot of arsenic concentrations, categorized by source ............................................21

11. Graph showing strontium isotope ratio versus strontium concentration for groundwater samples, categorized by source ...........................................................22

12. Map showing stable isotope ratios of oxygen and hydrogen in the study area ..............23

13. Graph showing relation between stable isotope ratios of oxygen and hydrogen

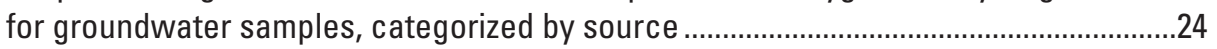

14. Graph showing noble gas recharge elevation and temperature for groundwater

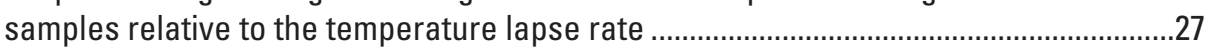

15. Map showing radiocarbon and tritium values in the study area......................................2

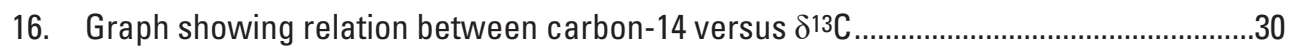

17. Nonmetric multidimensional scaling graph for groundwater samples ............................31

18. Cluster analysis dendogram for groundwater samples in the study area .......................32

19. Generalized geologic cross section $A-A$ ' between wells 19 and 12 utilizing driller's logs and geophysical survey (NS4) from Macy and others (2019) and geologic information from DeWitt and others (2008) .....................................................35

20. Aerial photo showing specific conductance in the Verde River on June $13,2018 \ldots \ldots . . . .38$

21. Graph showing stable isotopes of oxygen over time relative to daily discharge at Verde River near Paulden, Arizona . .40

22. Graph showing stable isotope ratio of oxygen versus stable isotope ratio of hydrogen for the Verde River near Paulden, Arizona

23. Graph showing stable isotopes of oxygen over time relative to daily discharge at Williamson Valley Wash near Paulden, Arizona.

24. Graph showing stable isotope ratio of oxygen versus stable isotope ratio of hydrogen for Williamson Valley Wash near Paulden, Arizona....

\section{Tables}

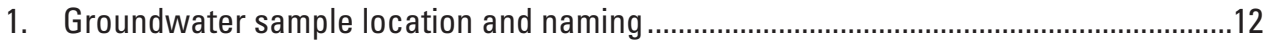

2. U.S. Environmental Protection Agency water-quality standards for drinking water......13

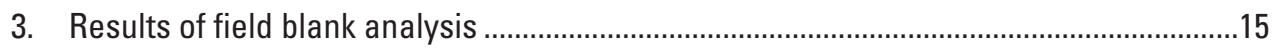

4. Replicate sample data for groundwater samples ..........................................................16

5. Noble gas data for groundwater samples collected in the study area ...........................25

6. Noble gas recharge elevation and temperature for groundwater samples

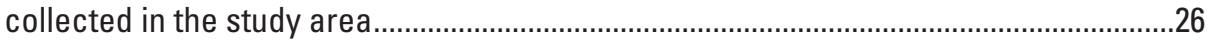

7. Apparent age of fraction of young tritiated water sampled in the study area .................27

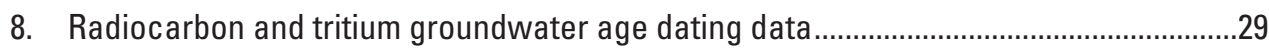

9. Groundwater chemistry comparison between this study and previous studies .............34

10. Groundwater chemistry of springs discharging to the Verde River and select groundwater sites 


\section{Conversion Factors}

U.S. customary units to International System of Units

\begin{tabular}{|c|c|c|}
\hline Multiply & By & To obtain \\
\hline \multicolumn{3}{|c|}{ Length } \\
\hline inch (in.) & 2.54 & centimeter $(\mathrm{cm})$ \\
\hline inch (in.) & 25.4 & millimeter (mm) \\
\hline inch (in.) & $2.54 \times 10^{4}$ & micrometer (um) \\
\hline foot $(\mathrm{ft})$ & 0.3048 & meter $(\mathrm{m})$ \\
\hline mile (mi) & 1.609 & kilometer $(\mathrm{km})$ \\
\hline \multicolumn{3}{|c|}{ Flow rate } \\
\hline cubic foot per second $(\mathrm{ft} 3 / \mathrm{s})$ & 0.02832 & cubic meter per second $\left(\mathrm{m}^{3 / \mathrm{s}}\right)$ \\
\hline \multicolumn{3}{|c|}{ Radioactivity } \\
\hline picocurie per liter (pCi/L) & 0.037 & becquerel per liter $(\mathrm{Bq} / \mathrm{L})$ \\
\hline
\end{tabular}

Temperature in degrees Celsius $\left({ }^{\circ} \mathrm{C}\right)$ may be converted to degrees Fahrenheit $\left({ }^{\circ} \mathrm{F}\right)$ as follows:

${ }^{\circ} \mathrm{F}=\left(1.8 \times{ }^{\circ} \mathrm{C}\right)+32$.

\section{Datum}

Vertical coordinate information is referenced to the North American Vertical Datum of 1988 (NAVD 88).

Horizontal coordinate information is referenced to the North American Datum of 1983 (NAD 83).

Elevation, as used in this report, refers to distance above the vertical datum.

\section{Supplemental Information}

Specific conductance is given in microsiemens per centimeter at 25 degrees Celsius $\left(\mu \mathrm{S} / \mathrm{cm}\right.$ at $\left.25^{\circ} \mathrm{C}\right)$.

Concentrations of chemical constituents in water are given in either milligrams per liter (mg/L) or micrograms per liter $(\mu \mathrm{g} / \mathrm{L})$.

Activities for radioactive constituents in water are given in picocuries per liter (pCi/L).

Results for measurements of stable isotopes of an element (with symbol E) in water, solids, and dissolved constituents commonly are expressed as the relative difference in the ratio of the number of the less abundant isotope $(\mathrm{i} E)$ to the number of the more abundant isotope of a sample with respect to a measurement standard.

The conversion of picocuries per liter to Tritium Units (TU), based upon a tritium half-life of 12.32 years (Lucas and Unterweger, 2000), is: 1 TU $=3.22$ picocuries per liter. 


\section{Abbreviations}

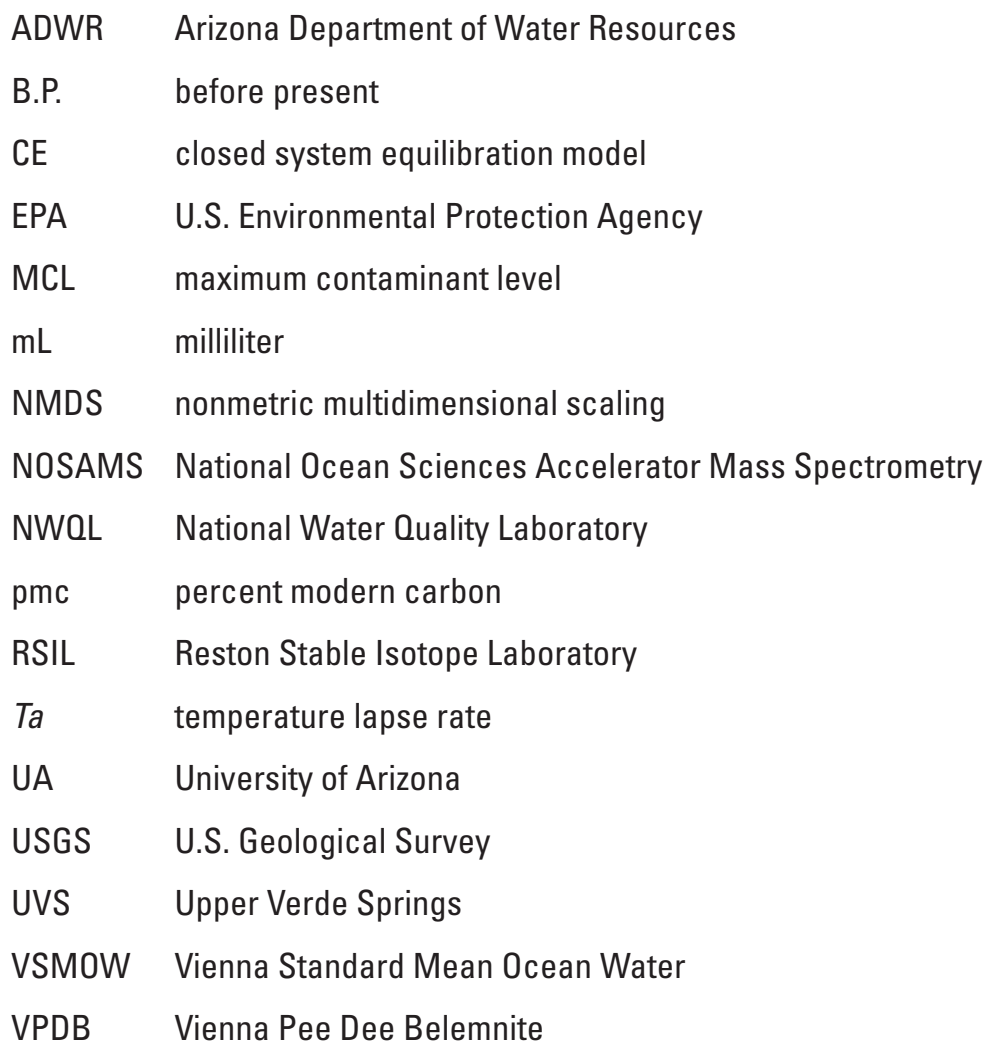




\title{
Geochemical Assessment of Groundwater in the Big Chino Subbasin, Arizona, 2011-18
}

\author{
By Kimberly R. Beisner and Casey J.R. Jones
}

\section{Abstract}

A geochemical characterization of groundwater in the Big Chino subbasin of Arizona was conducted by the U.S. Geological Survey, in cooperation with the City of Prescott, the Town of Prescott Valley, and the Salt River Project, to understand groundwater evolution through the study area and the source of water to springs along the gaining reach of the Verde River just downstream from its confluence with Granite Creek. Samples were collected between 2011 and 2018 in groundwater wells completed in basin-fill and carbonate aquifers and at selected springs, including two discrete springs discharging along the aforementioned stretch of the Verde River. Five newly installed monitoring wells completed in the carbonate aquifer were sampled in 2018 . Water-quality results obtained from these samples include the first known geochemical data for carbonate groundwater beneath the basin-fill in the Big Chino subbasin downgradient from Walnut Creek near Paulden, Arizona, as well as other parts of the study area without previous data. Groundwater samples were collected and analyzed for major ions, arsenic, nutrients, stable isotopes of oxygen and hydrogen $\left(\delta^{18} \mathrm{O}\right.$ and $\left.\delta^{2} \mathrm{H}\right)$, strontium isotopes $\left({ }^{87} \mathrm{Sr} /{ }^{86} \mathrm{Sr}\right)$, carbon- 14 , isotopes of carbon $\left(\delta^{13} \mathrm{C}\right)$, and noble gases.

Significant differences in groundwater geochemistry between the basin-fill and carbonate aquifers were driven primarily by higher $\mathrm{pH}$, tritium, and $\delta^{18 \mathrm{O}}$ and $\delta^{2} \mathrm{H}$ in the basinfill aquifer samples and higher specific conductance and higher concentrations of calcium, sodium, bicarbonate, fluoride, and arsenic in the carbonate aquifer samples. All but one sample from the carbonate aquifer and two samples from the basin-fill aquifer exceeded the U.S. Environmental Protection Agency (EPA) drinking water standard for arsenic of 10 micrograms per liter. One basin-fill aquifer sample exceeded the EPA drinking water standard for fluoride of 4 milligrams per liter, and one carbonate aquifer sample exceeded the EPA secondary drinking water standard for fluoride of 2 milligrams per liter. A component of modern groundwater recharged following aboveground nuclear testing beginning in the mid-1950s is present in some basin-fill and spring groundwater from this study. Groundwater that can be dated using radiocarbon decay is also present in the study area, with four groundwater samples indicating possible recharge during the Pleistocene with groundwater ages ranging from approximately 34,600 to 13,300 years before present. Other groundwater sampled during this study that can dated using radiocarbon decay ranged in age from about 7,500 to 1,100 years before present, indicating possible recharge during the Holocene.

The gaining reach of the Verde River downstream from the confluence with Granite Creek shows areal changes in temperature, $\mathrm{pH}$, and specific conductance, indicating multiple zones of groundwater input. Surface-water samples for analyses of $\delta^{18} \mathrm{O}$ and $\delta^{2} \mathrm{H}$ have been collected at the Verde River near Paulden, Ariz. streamgage (09503700) during discharge measurements since 2009, and a trend analysis of the $\delta^{18} \mathrm{O}$ and $\delta^{2} \mathrm{H}$ data indicated no significant trend exists for the 10-year period of record. Additional groundwater samples from the carbonate aquifer beneath the basin-fill upgradient and downgradient from Walnut Creek would provide valuable information to understand groundwater evolution along the Big Chino subbasin.

\section{Introduction}

The Verde River is a major perennial water resource in Arizona that begins within the Big Chino subbasin in a region whose population has more than doubled in size from 1985 to 2005 (fig. 1; Rothman and Mays, 2014). Population growth is associated with an increased demand on water resources. An understanding of the groundwater source and evolution through the Big Chino subbasin study area and the source of water to springs along the gaining reach of the Verde River just downstream from its confluence with Granite Creek is needed for informed decisions regarding water resources. To address this need, the U.S. Geological Survey (USGS), in cooperation with the City of Prescott, the Town of Prescott Valley, and Salt River Project, assessed the geochemical conditions of water resources in the Big Chino subbasin of Arizona in 2011-18. 


\section{Purpose and Scope}

The purpose of this report is to document the results of a study to collect geochemical data from the Big Chino subbasin and then characterize the aquifers to understand recharge elevations, water-rock interaction, and groundwater residence times using the best available methods. Differences between aquifers and changes along groundwater flow paths can indicate aquifer connectivity within the system. Samples were collected from wells and springs between 2011 and 2018.

\section{Study Area}

The Big Chino subbasin lies within the Transition Zone, a region of physiographic and tectonic change between the Colorado Plateau Province to the northeast, and the Basin and Range Province to the southeast (Pierce, 1985; Ostenaa and others, 1993; Wirt and others, 2005a) (fig. 1).

The study area is located in a semidesert grassland surrounded by Great Basin conifer woodland biotic communities (HabiMap Arizona, 2019). Annual precipitation ranges from about 10 to 15 inches (in.) in the basins to around 20 to $40 \mathrm{in}$. at the mountain crests (Blasch and others, 2006). Precipitation primarily occurs during two seasons, namely the summer monsoon season, which is characterized by shortlived, intense, and localized convective rainstorms (July through September) and the winter season, which is characterized by longer-lived, less intense, and more regional frontal precipitation events (December through March). In central Arizona, precipitation totals for June are low relative to totals for subsequent months when summer monsoon rains occur.

\section{Geology}

The stratigraphy in the study area consists of Proterozoic igneous and metamorphic rocks overlain by a sequence of Paleozoic (Cambrian to Permian) sedimentary rocks, in turn overlain by Tertiary volcanic rocks and younger alluvial sedimentary deposits (fig. 2). The Devonian Martin Formation and Mississippian Redwall Limestone compose the dominant carbonate bedrock aquifer in the study area.

The Big Chino Fault trends northwest to southeast and is located along the base of the mountain front where the carbonate units of Paleozoic age are displaced below the basin-fill to the southwest from the mountains to the northeast of Big Chino Wash (DeWitt and others, 2008) (fig. 3). The displacement is greatest near the fault, and a series of grabens sequentially offset the bedrock away from the fault (Wirt and others, 2005a; Langenheim and others, 2005c). Driller's logs for wells completed in or below the basin-fill indicate that Tertiary volcanic flows intertongue with clastic sedimentary deposits (DeWitt and others, 2005). Fine-grained Tertiary playa deposits are documented in well logs and present in drill cuttings of the basin-fill of Big Chino Wash and create locally confining conditions, but the extent of the confinement is unknown (DeWitt and others, 2005).

\section{Hydrology}

The Verde River is the major perennial surface-water feature in the study area. Big Chino Wash is currently an ephemeral water feature that primarily flows toward the southeast, parallel to the Big Chino Fault, in response to monsoon rain events and occasional snowmelt events. Partridge Creek, Pine Creek, Walnut Creek, and Williamson Valley Wash are tributaries of Big Chino Wash and are also intermittent surface-water features. Granite Creek flows toward the north and drains into the Verde River below Stillman Lake (fig. 4).

Groundwater in the Big Chino subbasin is primarily in the basin-fill aquifers and carbonate aquifers. The groundwater in the basin-fill aquifer moves from the northwest toward the southeast along the axis of Big Chino Valley and deviates toward the south midway through the valley near Walnut Creek before it continues southeast toward Paulden (Arizona Department of Water Resources [ADWR], 2019). Groundwater flow in the carbonate units is less defined than in the basin-fill units because of a lack of wells completed in the carbonate units beneath the basin-fill in Big Chino Valley. In the carbonate aquifer, ADWR (2019) depicts northward groundwater flow from Ash Fork toward the Grand Canyon and eastward groundwater flow from Big Black Mesa toward Perkinsville (ADWR, 2019, fig. 5.5-6).

Karstic conditions exist in the Paleozoic carbonate units of the Colorado Plateau to the north and east of the study area (Jones and others, 2017) and likely exist in the carbonate units of the Big Chino subbasin (Wirt and others, 2005a). Karstic features can be enhanced in areas of structural offset of carbonate units and can affect groundwater flow direction and speed. Regionally, northwest striking features in the Colorado Plateau are open to fluid flow (Thorstenson and Beard, 1998). Permeable features derived from structural and (or) karstic conditions can change over time; for example, where mineral precipitation along permeable features over long geologic time periods can restrict a once-permeable zone and make it a barrier to flow. Knowledge about the location and closed or open nature of permeable structural features is needed to better understand groundwater flow dynamics in the study area.

Structural features are present along a 1-mile (mi) segment of the Verde River downstream from Granite Creek (Krieger, 1965; Gootee and others, 2011) where the river gains a large amount of discharge (approximately 20 cubic feet per second [ $\left[\mathrm{ft}^{3} / \mathrm{s}\right]$; Wirt, 2005) (fig. 5), hereafter referred to as the "gaining reach." A similar gaining reach is located in the Mormon Pocket area downstream from the study area (approximately $20 \mathrm{ft} 3 / \mathrm{s}$ in $0.75 \mathrm{mi}$; Beisner and others, 2018). The dip of the Martin Formation along the gaining reach downstream from Granite Creek ranges from 2 to 7 degrees to the west for rocks north of the river and 4 to 8 degrees to the northwest for rocks south of the river (Gootee and others, 2011).

The dominant faults along the gaining reach of the Verde River downstream from Granite Creek trend toward the northnortheast and are primarily observed in the exposed Martin Formation south of the Verde River; these faults are not shown 


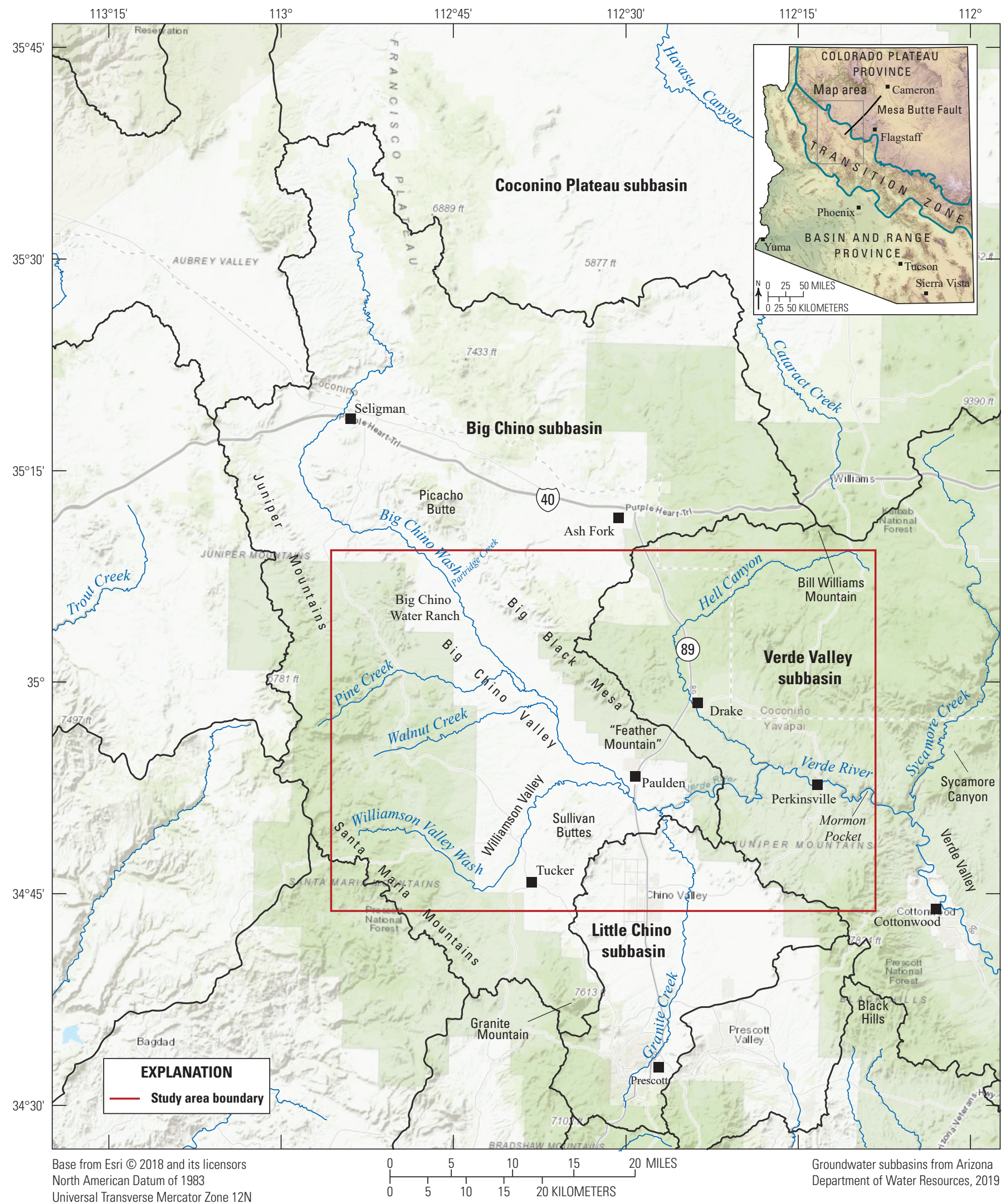

Figure 1. Big Chino subbasin study area and features mentioned in this report. Location map shows study area in context of Arizona physiography and Mesa Butte fault system, modified from Macy and others (2019). Location of Mesa Butte Fault from Conway and others (1997). 
Figure 2. Geologic stratigraphic section from Big Chino subbasin study area, modified from Macy and others (2019). Geologic unit abbreviations are derived from DeWitt and others (2008).

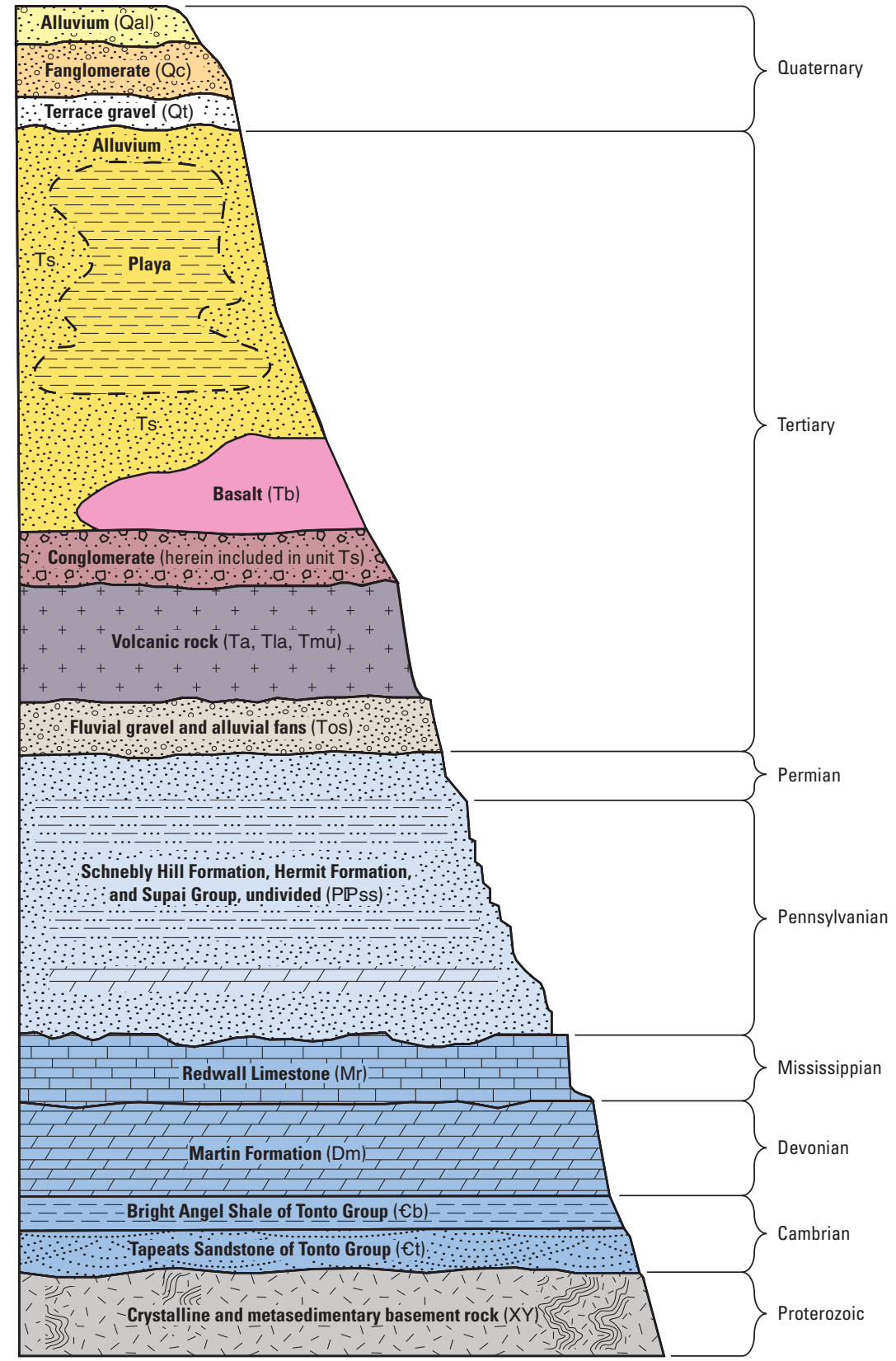

Mesa Butte fault system is proposed to extend from Chino Valley to Shadow Mountain (near Cameron, Arizona) and is concealed beneath Tertiary volcanic rocks (Shoemaker and others, 1974). The fault system was mapped in Hell Canyon and south of the Verde River with displacement in Proterozoic rocks (Krieger, 1965). Macy and others (2019) inferred the presence of potential faults in the subsurface from large, abrupt changes in the depth of crystalline basement rock beneath the surficial volcanic rocks to the northeast and west of the gaining reach of the Verde River.

During this study, groundwater discharge into the Verde River was observed at two discrete springs (referred to as "Upper Verde Springs" ([UVS] herein) located near the geologic features just described (fig. 5). It is likely that additional half a million years and evidence of Holocene seismic activity (Damon and others, 1974; Shoemaker and others, 1974). The to extend into the Tertiary volcanic units north of the Verde faults extend to the northwest of the main faults and perpendicularly cross the Verde River in the gaining reach (fig. 5; faults were mapped by Krieger (1965), but no faults crossing the Verde River in the gaining reach are shown on the larger system is a northeast trending, deep seated regional feature that is presumed to originate from an ancestral fault system in Proterozoic rocks. There has been Cenozoic movement constrained by offset within volcanic rocks older than about a 
groundwater discharge to the river occurs below the riverbed or as diffuse inflow (Wirt, 2005). Changes in the river channel are likely to occur over time, primarily following large flow events, and may change the location and form of expression of the groundwater discharges to the Verde River.

\section{Previous Studies}

Early geologic and hydrologic studies in the Big Chino subbasin began with a geologic description of the Paulden and Prescott quadrangles, including an assessment of water resources in the Prescott area (Krieger, 1965). A water-level contour map was created by Wallace and Laney (1976) and later updated by Schwab (1995) to include major cation and anion data. Levings and Mann (1980) mapped the potentiometric surface and discrete specific conductance from well samples in central Arizona, including an eastern section of the Big Chino subbasin; Owen-Joyce and Bell (1983) described physical and chemical characteristics of the aquifers and surface water in the same study area. Predevelopment hydrologic conditions in alluvial aquifers in both the Big Chino and Little Chino subbasins were presented by Freethy and Anderson (1986).

More detailed analyses involving the geochemistry of the Big Chino subbasin have since been completed. Ewing and others (1994) conducted a seepage isotope-tracer test (hydrogen $\left[\delta^{2} \mathrm{H}\right]$, oxygen $\left[\delta^{18} \mathrm{O}\right]$, carbon $\left[\delta^{13} \mathrm{C}\right]$, and tritium) of the Verde River and sampled wells in the Big and Little Chino subbasins, resulting in two steady-state groundwater models. Knauth and Greenbie (1997) collected stable-isotope data $\left(\delta^{2} \mathrm{H}\right.$ and $\left.\delta^{18} \mathrm{O}\right)$ for the upper $5 \mathrm{mi}$ of the Verde River and several surrounding wells, including wells in the Big Chino subbasin. Wirt and Hjalmarson (2000) compared isotope data from the two aforementioned studies with new isotope samples collected in $1999\left(\delta^{2} \mathrm{H}, \delta^{18} \mathrm{O}, \delta^{13} \mathrm{C}\right.$, and tritium), which were coupled with geologic information, groundwater levels, streamflow and precipitation records, and an analysis of waterbudget components to deduce the aquifer sources of base flow to the UVS. The authors concluded that at least 80 percent of the base flow to the UVS flowed from interconnected basin-fill and carbonate aquifers in the Big Chino Valley.

A comprehensive study was presented by Wirt and others (2005a) to provide a hydrogeologic framework of the aquifers surrounding the Verde River, identify groundwater flow paths, and reassess sources of base flow to the upper Verde River springs. As part of this study, the geologic framework was evaluated by new mapping, chemical analysis, X-ray diffraction studies, and a synthesis of well logs and cross sections (DeWitt and others, 2005). Wirt and others (2005b) described the hydrogeologic framework and groundwater flow of the Big Chino alluvial basin, the Little Chino alluvial basin, and the underlying carbonate aquifer. Wirt and DeWitt (2005) contributed to the geochemical data in the study area by sampling for major and trace elements, tritium, and stable isotope ratios of hydrogen, oxygen, and carbon $\left(\delta^{2} \mathrm{H}, \delta^{18} \mathrm{O}, \delta^{13} \mathrm{C}\right)$, and carbon-14 $\left({ }^{14} \mathrm{C}\right)$ isotopes at wells and springs. From this data, the authors determined that the Big Chino subbasin outlet flow path is from the basin-fill aquifer through the DevonianCambrian zone of the underlying carbonate aquifer. Wirt (2005) conducted a sodium-chloride tracer dilution study and synoptic water-chemistry sampling to determine the relative contributions from surrounding aquifers and used inverse modeling to quantify the extent of mixing between the Big Chino aquifer and upper Verde River springs.

Blasch and others (2006) detailed climatic, geologic, and hydrologic data in the Big Chino subbasin, Little Chino subbasin, and Verde Valley. Water chemistry data (major ions, trace elements, and stable isotopes $\left[\delta^{2} \mathrm{H}\right.$ and $\left.\delta^{18} \mathrm{O}\right]$ ) were compiled from previous studies and supplemented with new data to quantify fractions of source waters from surrounding groundwater areas by means of a geochemical mixing model. A water budget for each subbasin and regional aquifer was developed from estimated inflows and outflows to the system. The study yielded a conceptual model of the hydrologic system that described the recharge mechanisms, discharge points, and groundwater flow paths of the regional aquifers. The authors concluded that the groundwater flow into Big Chino Valley, located in the Big Chino subbasin, likely enters from the Redwall-Muav aquifer east and west of Big Black Mesa and northward from the Little Chino subbasin near Del Rio Springs (figs. 1 and 2). Major sources of recharge include the Juniper Mountains, Santa Maria Mountains, and Big Black Mesa. Groundwater residence time in the Big Chino Valley is approximately 6,000 years.

Geophysical studies have also been completed to further describe the hydrology in the Big Chino subbasin. Langenheim and others (2005a, b) analyzed aeromagnetic and gravity data in the upper and middle Verde River watersheds and surrounding areas. In southern Big Chino Valley, latiandesite plugs buried less than 1,000 feet (ft) below valley fill were described as possibly being resistant to groundwater flow. The depth to basement rock was calculated, and multiple faults and fractures with and without obvious surface expressions were delineated. Kennedy and others (2019) used repeat microgravity measurements to determine aquiferstorage change, groundwater-level change, and aquiferconfining properties in the southern part of the Big Chino subbasin between 2010 and 2017. There were no substantial recharge events during this period, and groundwater storage and groundwater levels showed declines in many parts of the study area. Controlled-source audio-frequency magnetotelluric surveys were conducted in the southern third of the Big Chino subbasin by Macy and others (2019) to more accurately constrain aquifer and lithologic extents that contribute to aquifer storage properties.

\section{Methods}

This section describes field methods for collection and analyses of groundwater samples. Methods for data analyses also are described. 


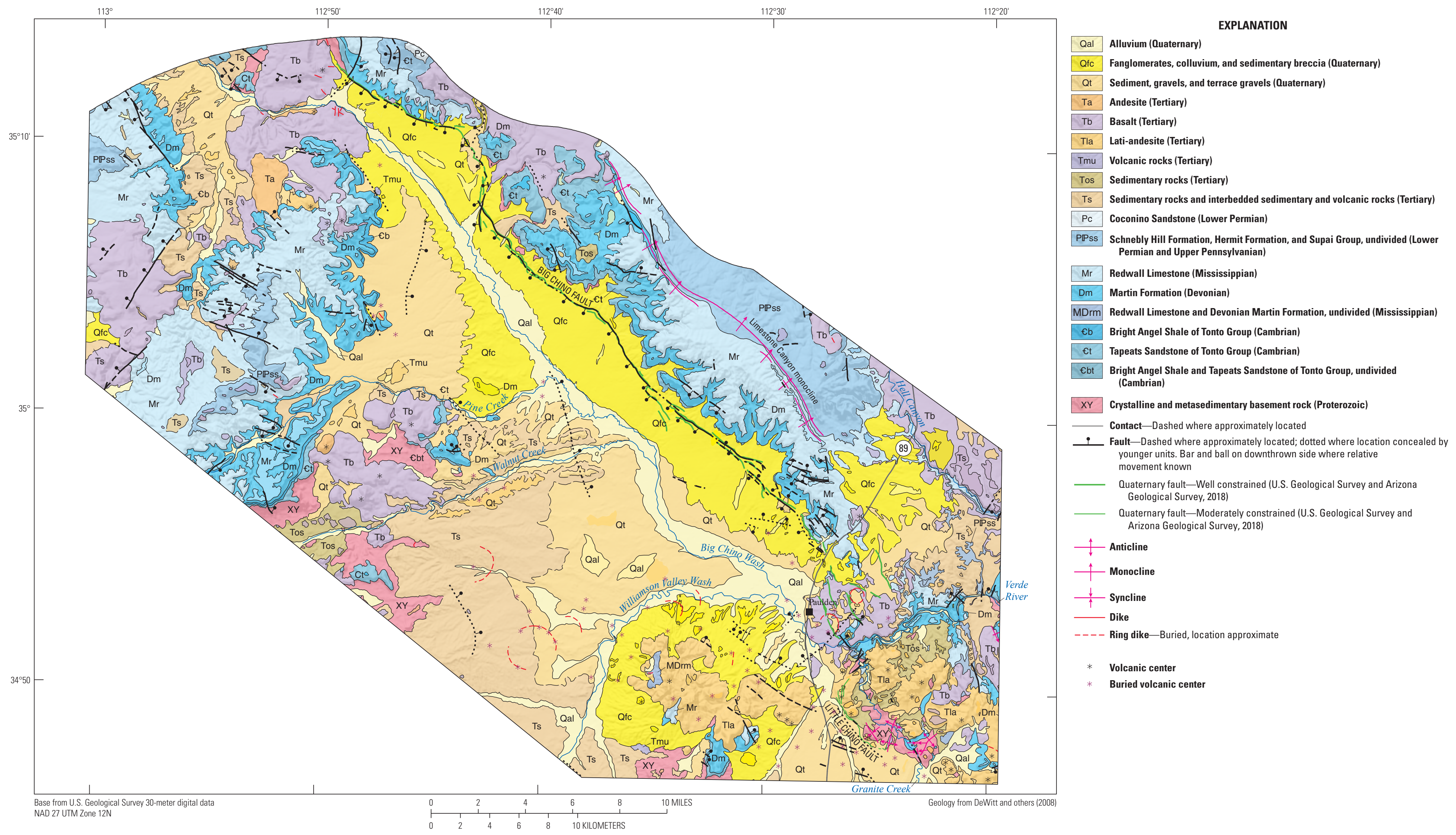

Figure 3. Geology of the Big Chino study area. Modified from Macy and others (2019). Geology from DeWitt and others (2008). 


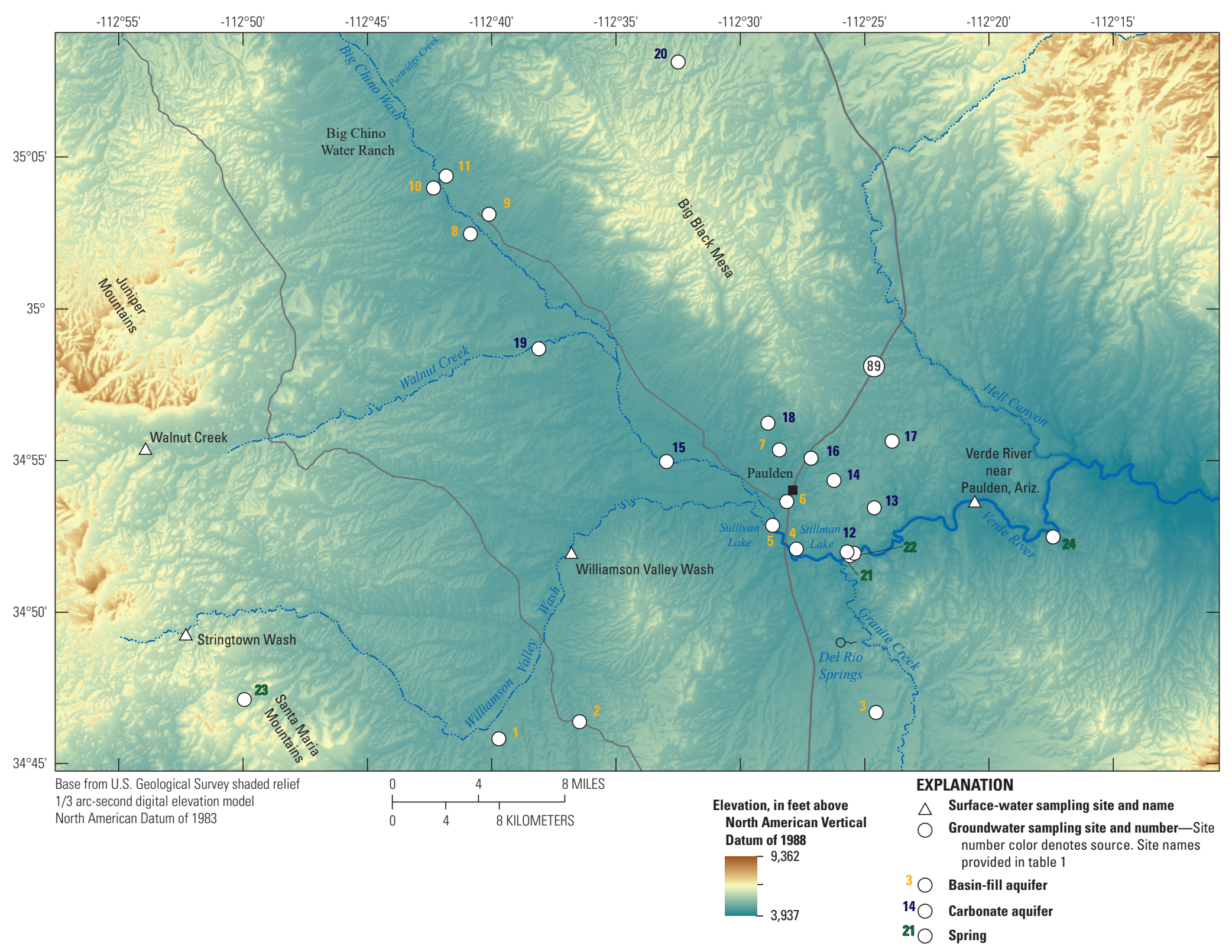

Figure 4. Groundwater and surface-water sampling locations and surface-water features in the Big Chino subbasin study area. 


\section{Field}

Groundwater samples were collected for water-quality analyses from 20 wells and 4 springs following standard USGS protocols (table 1; U.S. Geological Survey, variously dated). Before water samples were collected, field properties including $\mathrm{pH}$, water temperature, specific conductance, dissolved oxygen, and barometric pressure were measured in a flow-through cell during well purging at each sampling site. Well discharge was measured by field personnel using volumetric techniques or was reported by the owner. Water level, casing dimensions, and pumping rate were used to calculate the purge volume and time required to purge three casing volumes prior to sample collection.

Water samples were filtered ( 0.45 micrometer pore size $)$ for major cations, trace elements, alkalinity, nutrients, ${ }^{14} \mathrm{C}$, and strontium isotopes. The major cations, trace elements, and strontium isotope samples were preserved to $\mathrm{pH}<2$ by adding ultrapure nitric acid. Unfiltered samples were collected to be analyzed for tritium and stable isotopes. Alkalinity (field) was computed from titration data using the incremental equivalence method (U.S. Geological Survey, variously dated).

Radon-222 (222Rn) samples were collected using a glass syringe and needle. Then 10 milliliters $(\mathrm{mL})$ was discharged from the needle beneath a $10-\mathrm{mL}$ mineral oil cocktail solution in a scintillation vial according to methods in the USGS National Field Manual (U.S. Geological Survey, variously dated). Noble gas samples were collected in copper tubes (two per sample), which were sealed with refrigerator clamps (Weiss, 1968). Back pressure was applied with a restrictor on the sample tubing past the copper tube to minimize bubble formation prior to sealing the samples.

Two field blank samples were collected using certified inorganic blank water, and two replicate samples were collected. These samples represent quality assurance and quality control for this study.

\section{Analytical}

Water samples were analyzed for major cations, trace elements, and nutrients by the USGS National Water Quality Laboratory (NWQL) in Denver, Colorado. Analytical methods from the USGS NWQL included inductively coupled plasma mass spectrometry to determine arsenic concentration (Garbarino and others, 2006). Inductively coupled plasma atomic emission spectrometry was used to analyze for cations (calcium, iron, magnesium, manganese, potassium, and sodium) (Fishman, 1993). Anions (chloride, fluoride, and sulfate) were analyzed by ion chromatography, and $\mathrm{SiO}_{2}$ was analyzed by discrete analyzer colorimetry (Fishman and Friedman, 1989). Nitrate $\left(\mathrm{NO}_{3}\right)$ plus nitrite $\left(\mathrm{NO}_{2}\right)$ were analyzed by colorimetry (Patton and Kryskalla, 2011).

Stable isotope ratios $\left(\delta^{18} \mathrm{O}\right.$ and $\left.\delta^{2} \mathrm{H}\right)$ were measured at the University of Arizona (UA) Environmental Isotope Laboratory, Tucson, Ariz. through 2012 and the USGS Reston Stable Isotope Laboratory (RSIL) in Reston, Virginia, from
2013 to 2018. UA samples were analyzed using a gas-source isotope ratio mass spectrometer (Finnigan Delta $\mathrm{S}$ ). For hydrogen, samples were reacted at 750 degrees Celsius $\left({ }^{\circ} \mathrm{C}\right)$ with chromium metal using a Finnigan H/Device coupled to the mass spectrometer. For oxygen, samples were equilibrated with carbon dioxide $\left(\mathrm{CO}_{2}\right)$ gas at approximately $15{ }^{\circ} \mathrm{C}$ in an automated equilibration device coupled to the mass spectrometer. Standardization is based on international reference materials, Vienna Standard Mean Ocean Water (VSMOW) and Standard Light Antarctic Precipitation. Precision is 0.9 per mil or better for $\delta^{2} \mathrm{H}$ and 0.08 per mil or better for $\delta^{18} \mathrm{O}$ on the basis of repeated internal standards. RSIL samples were analyzed using mass spectrometry following methods by Révész and Coplen (2008a, b). The two-sigma uncertainties are 0.2 per mil for oxygen and 2 per mil for hydrogen isotopic ratios reported relative to VSMOW.

Strontium isotope ratios $\left({ }^{87} \mathrm{Sr} / 86 \mathrm{Sr}\right)$ were measured by the USGS National Research Program Laboratory in Menlo Park, California, by using multicollector mass spectrometry following methods described in Bullen and others (1996) and are precise to 0.00002 or better at the 95 -percent confidence level.

Noble gases (helium, neon, argon, krypton, and xenon) were analyzed by the USGS Noble Gas Laboratory, Lakewood, Colo. (Hunt, 2015). ${ }^{3} \mathrm{H}$ (tritium) $/ 3 \mathrm{He}$ age was calculated by using $2 \times 10^{-8}$ for the terrigenic helium (Plummer and others, 2012). 222Rn was analyzed by liquid scintillation methods at the USGS NWQL using method ASTM D 5072-98 (ASTM, 2016). The laboratory reporting level was 20 picocuries per liter $(\mathrm{pCi} / \mathrm{L})$.

Tritium was measured at the USGS Noble Gas Laboratory by helium ingrowth methods for samples collected between 2012 and 2015 (Bayer and others, 1989). The University of Miami Tritium Laboratory in Miami, Florida, measured tritium in samples collected in 2017 and 2018 using the electrolytic enrichment and gas-counting method, with a reporting limit of $0.3 \mathrm{pCi} / \mathrm{L}$. Tritium, ${ }^{14} \mathrm{C}$, and $\delta^{13} \mathrm{C}$ were analyzed at the University of Arizona Accelerator Mass Spectrometry Laboratory in $2011 .{ }^{14} \mathrm{C}$ and $\delta^{13} \mathrm{C}$ were analyzed by the National Ocean Sciences Accelerator Mass Spectrometry (NOSAMS) at the Woods Hole Oceanographic Institution, Massachusetts, for samples collected between 2012 and 2018.

\section{Data Analysis}

The data were analyzed using statistical methods to understand similarities and differences between samples within and between groups. Boxplots for elements were made using the "boxplot" function in the R statistical computing environment (R Core Team, 2020). Outlier data points on boxplots were defined for this study as being greater than 1.5 times the interquartile range.

Samples were grouped by groundwater type; namely basinfill, carbonate, and spring; basin-fill and carbonate groundwater groups were then compared using "wilcox.test" (R Core Team, 2020). Trends were assessed using the trend package in $R$ with 


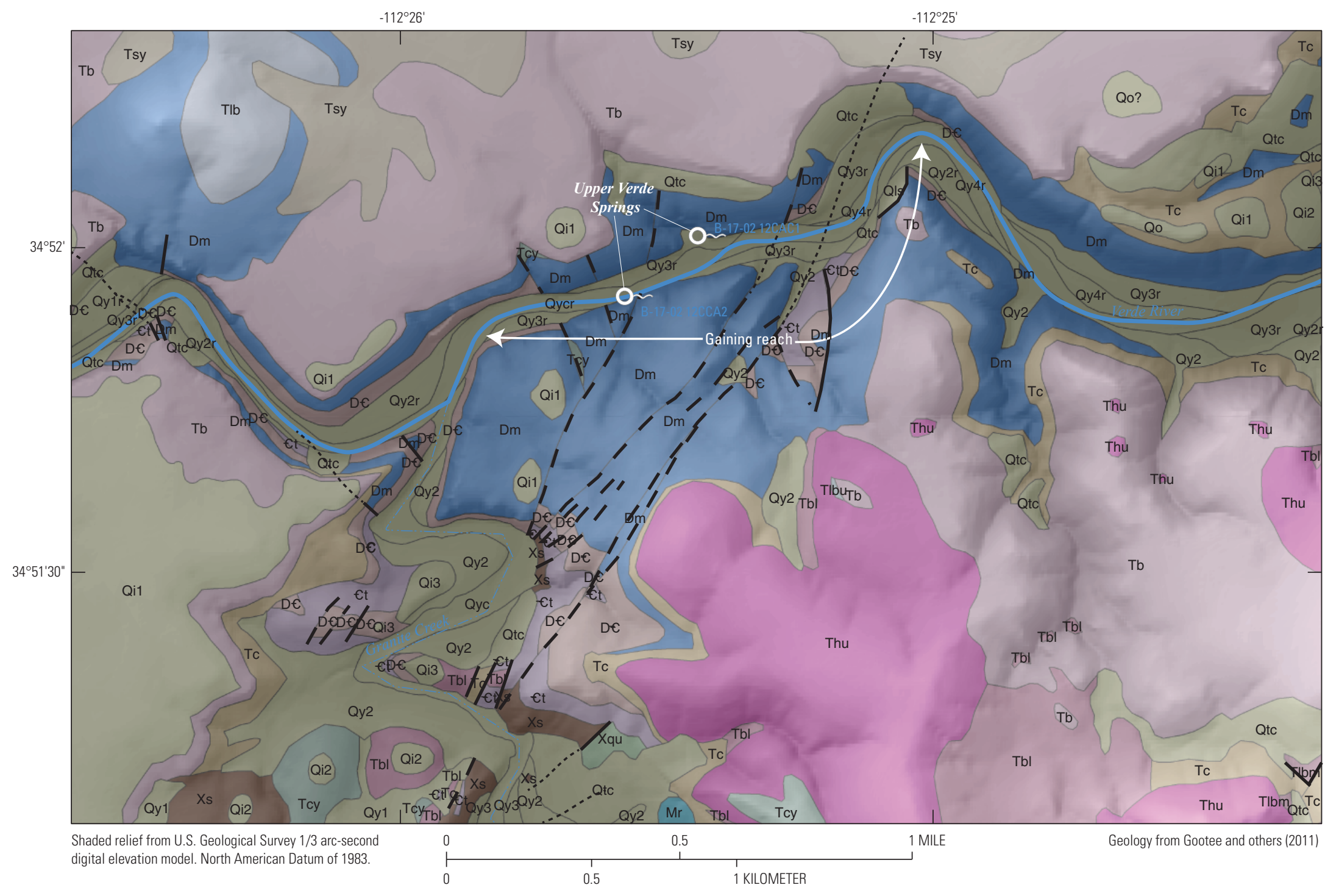




\begin{tabular}{|c|c|}
\hline Qtc & Talus and colluvium (Quaternary) \\
\hline Qycr & Active river channel deposits \\
\hline Qy4r & Flood channel and low terrace deposits \\
\hline ay3r & River terrace deposits (historical) \\
\hline Qy2r & River terrace deposits (latest Holocene to historical) \\
\hline Qy1r & River terrace deposits (late to early Holocene) \\
\hline Oyc & Active tributary channel alluvium \\
\hline Qy4 & Alluvium (latest Holocene to modern) \\
\hline Qy3 & Alluvium (latest Holocene) \\
\hline Qy2 & Alluvium (late Holocene) \\
\hline 0y1 & Alluvium (early to late Holocene) \\
\hline Qi3 & Alluvium (Iate Pleistocene) \\
\hline Qi2 & Alluvium (middle to late Pleistocene) \\
\hline 0o & Alluvium (early Pleistocene) \\
\hline
\end{tabular}

\section{EXPLANATION}

Conglomerate (Tertiary) Contact

Younger siliciclastic conglomerate (Tertiary) —— Fault—Dashed where approximately located; dotted

Younger siliciclastic conglomerate (Tertiary) where location concealed by younger units

Younger mafic lava, undifferentiated (Tertiary) Spring

Volcaniclastic conglomerate and breccia (Tertiary)

Biotite latite, undifferentiated (Tertiary)

Upper biotite latite (Tertiary)

Upper hornblende latite (upper Tertiary)

Middle biotite latite (Tertiary)

Lower mafic lava and pyroclastic complex (Tertiary)

Redwall Limestone (Mississippian)

Martin Limestone (Devonian)

Undifferentiated rocks (Devonian and Cambrian)

Tapeats Sandstone of Tonto Group (Cambrian)

Metasedimentary rocks (Paleoproterozoic)

Figure 5. Geologic setting along a gaining reach near the headwaters of the Verde River. Geology modified from Gootee and others (2011) and gaining reach extent from Wirt (2005). 
Table 1. Groundwater sample location and naming.

[Common name for site is given in brackets [ ] following cadastral site name. Latitude and longitude are in decimal degrees North American Datum of 1983. Elevation is reported in feet above the North American Vertical Datum of 1988. Sites 21 and 22 represent some of the Upper Verde Springs (UVS). USGS, U.S. Geological Survey; ADWR, Arizona Department of Water Resources; NA, not available]

\begin{tabular}{|c|c|c|c|c|c|c|c|c|}
\hline $\begin{array}{c}\text { Site } \\
\text { number }\end{array}$ & $\begin{array}{l}\text { Agency } \\
\text { code }\end{array}$ & $\begin{array}{c}\text { USGS } \\
\text { site identifier }\end{array}$ & Site name & Latitude & Longitude & Elevation & $\begin{array}{l}\text { Aquifer } \\
\text { type }\end{array}$ & $\begin{array}{c}\text { ADWR well } \\
\text { registry } \\
\text { number }\end{array}$ \\
\hline \multicolumn{9}{|c|}{ Basin-fill aquifer } \\
\hline 1 & USGS & 344552112394001 & B-16-04 14CCB1 & 34.7647 & -112.6618 & 4,630 & Basin-fill & $55-605433$ \\
\hline 2 & AZ014 & 344627112362501 & B-16-03 17BBD1 & 34.7741 & -112.6078 & 4,680 & Basin-fill & $55-589659$ \\
\hline 3 & USGS & 344645112243201 & B-16-01 07CBD1 & 34.7792 & -112.4090 & 4,665 & Basin-fill & $55-589793$ \\
\hline 4 & AZ014 & 345209112274001 & B-17-02 10CAC1 & 34.8692 & -112.4624 & 4,393 & Basin-fill & $55-519184$ \\
\hline 5 & AZ014 & 345300112283701 & $\mathrm{~B}-17-02 \mathrm{~S} 04 \mathrm{DBC} 3$ [PZ1] & 34.8822 & -112.4784 & 4,362 & Basin-fill & $55-524078$ \\
\hline 6 & USGS & 345343112280501 & B-17-02 03BBB1 & 34.8952 & -112.4688 & 4,395 & Basin-fill & $55-561786$ \\
\hline 7 & USGS & 345525112282601 & B-18-02 28AAB1 & 34.9237 & -112.4738 & 4,505 & Basin-fill & $55-581763$ \\
\hline 8 & AZ014 & 350232112404901 & B-19-04 10CCB2 [WMW 3] & 35.0422 & -112.6810 & 4,531 & Basin-fill & $55-210659$ \\
\hline 9 & USGS & 350311112400501 & B-19-04 10AAC & 35.0531 & -112.6685 & 4,563 & Basin-fill & NA \\
\hline 10 & USGS & 350403112421801 & B-19-04 05ABA1 [TW\#1] & 35.0675 & -112.7057 & 4,574 & Basin-fill & $55-905230$ \\
\hline 11 & AZ014 & 350427112414701 & B-20-04 33CBD2 [WMW 2] & 35.0741 & -112.6972 & 4,555 & Basin-fill & $55-210660$ \\
\hline \multicolumn{9}{|c|}{ Carbonate aquifer } \\
\hline 12 & USGS & 345203112254201 & B-17-02 12CBD1 [4e] & 34.8675 & -112.4283 & 4,463 & Carbonate & $55-228263$ \\
\hline 13 & USGS & 345331112243701 & B-18-01 31CCC1 [4b3] & 34.8918 & -112.4102 & 4,606 & Carbonate & $55-228262$ \\
\hline 14 & USGS & 345425112261401 & B-18-02 35ABA1 & 34.9069 & -112.4373 & 4,580 & Carbonate & $55-917475$ \\
\hline 15 & USGS & 345502112325801 & B-18-03 26BDD2 [4g] & 34.9172 & -112.5495 & 4,403 & Carbonate & $55-921236$ \\
\hline 16 & USGS & 345509112270901 & B-18-02 26BBC1 & 34.9191 & -112.4526 & 4,565 & Carbonate & $55-912454$ \\
\hline 17 & USGS & 345542112235401 & B-18-01 19ADC1 [4b2] & 34.9284 & -112.3982 & 4,641 & Carbonate & $55-228265$ \\
\hline 18 & USGS & 345618112285301 & B-18-02 21BAB1 & 34.9384 & -112.4815 & 4,595 & Carbonate & $55-512240$ \\
\hline 19 & USGS & 345845112380601 & B-18-04 01ABD1 [BMW2] & 34.9793 & -112.6350 & 4,560 & Carbonate & $55-921256$ \\
\hline 20 & USGS & 350820112323601 & $\mathrm{~B}-20-0311 \mathrm{AAC} 1$ & 35.1366 & -112.5417 & 5,290 & Carbonate & $55-588163$ \\
\hline \multicolumn{9}{|c|}{ Springs } \\
\hline 21 & USGS & 344709112495501 & B-17-02 12CCA2 [UVS South] & 34.8654 & -112.4263 & 4,240 & Spring & NA \\
\hline 22 & USGS & 345155112253501 & B-17-02 12CAC1 [Greenbie Pool] & 34.8669 & -112.4240 & 4,240 & Spring & NA \\
\hline 23 & USGS & 345201112252601 & B-16-05 06SBBC [Cabin Spring] & 34.7864 & -112.8325 & 5,570 & Spring & NA \\
\hline 24 & USGS & 345235112172501 & A-17-01 07AAA UNSURV [Duff Spring] & 34.8758 & -112.2903 & 4,055 & Spring & NA \\
\hline
\end{tabular}


the "mk.test" function (Pohlert, 2020). A p-value threshold of 0.05 (95-percent confidence level) was used to indicate statistical significance for all mentioned statistical tests.

Nonmetric multidimensional scaling (NMDS) was used to reduce the complex data structure (many samples and many elements) to represent the pairwise dissimilarity between objects in a low-dimensional space (Clarke and others, 2014, p. 5-6). Uscores of the data were computed using the "uscore" function for R from Helsel (2016) with default values to calculate the ranks of the scores (Helsel, 2012, 2016). NMDS was performed on the Uscores using metaMDS from the vegan package in R (Oksanen and others, 2016) using Euclidean distance, where zerodist $=$ add and autotransform $=$ false $(\mathrm{Helsel}$, 2012). NMDS stress values $\leq 0.1$ are considered fair with good ordination and no real prospect of misleading interpretation; values $\leq 0.05$ indicate good fit, and values $\geq 0.2$ are deemed suspect (Clarke and others, 2014, p. 5-6).

A cluster analysis was used to identify similar groups of samples by evaluating minimum differences within groups and maximum differences among groups using the "hclust" function with Euclidian distance matrix for the elements used in the NMDS analysis. The Calinski criterion was applied with the "cascadeKM" function of the vegan package in $\mathrm{R}$ (Oksanen and others, 2016) to determine the number of clusters that maximizes the difference between clusters while minimizing the differences within clusters.

Water sample concentrations were compared to the U.S. Environmental Protection Agency (EPA) drinking water standards presented in table 2 (U.S. Environmental Protection Agency, 2019a, b).

${ }^{14} \mathrm{C}$ values (reported by NOSAMS as absolute percent modern carbon) were denormalized using equation 5 of Plummer and others (2012) to percent modern carbon (pmc).
NetpathXL computed corrected groundwater ages using model 11 "Revised F\&G solid ex" (Han and Plummer, 2013; Parkhurst and Charlton, 2008). Groundwater age was computed with ${ }^{14} \mathrm{C}$ value of $0 \mathrm{pmc}$ for carbonate rock and $100 \mathrm{pmc}$ for soil $\mathrm{CO}_{2}$, assuming $\delta^{13} \mathrm{C}$ values of -1.85 per mil for carbonate (Muller and Mayo, 1986) and -12 and -18 per mil for soil $\mathrm{CO}_{2}$ (Beisner and others, 2019).

Recharge temperature was calculated using recharge elevation and $\mathrm{Ne}, \mathrm{Ar}, \mathrm{Kr}$, and $\mathrm{Xe}$ with the closed system equilibration model (CE) (Aeschbach-Hertig and others, 2000) using a standard inverse technique (Newton method) to minimize the error-weighted misfit $\left(\mathrm{Chi}^{2}\right)$ between measured and modeled values (Aeschbach-Hertig and others, 1999; Ballentine and Hall, 1999; Manning and Solomon, 2003).

A local relation between recharge temperature and elevation can place useful constraints on recharge elevation (Zuber and others, 1995; Aeschbach-Hertig and others, 1999; Manning and Solomon, 2003). A temperature lapse rate (Ta) was calculated for the Verde River watershed (presented in equation 1 from Beisner and others [2018] and modified here for elevation, in feet) using mean annual air temperature from available weather stations located at different elevations with a decrease of $8.1^{\circ} \mathrm{C}$ per 1,000 meters $[\mathrm{m}]$ ), which is similar to the slope of $8.7^{\circ} \mathrm{C}$ per $1,000 \mathrm{~m}$ from Johnson and others (2012) from the Verde River watershed.

$$
T a=-0.0025 z+25.432
$$

where

$$
\begin{gathered}
\text { Ta is the recharge temperature, in degrees } \\
\text { Celsius; and } \\
z \quad \text { is the recharge elevation, in feet. }
\end{gathered}
$$

\begin{tabular}{|c|c|c|c|c|c|}
\hline \multirow[t]{2}{*}{ Analyte } & \multirow[t]{2}{*}{ Units } & \multirow{2}{*}{$\begin{array}{c}\begin{array}{c}\text { Primary } \\
\text { drinking water } \\
\text { standard }\end{array} \\
\text { MCL }\end{array}$} & \multirow{2}{*}{$\begin{array}{c}\begin{array}{c}\text { Secondary } \\
\text { drinking water } \\
\text { standard }\end{array} \\
\text { SMCL }\end{array}$} & \multicolumn{2}{|c|}{$\begin{array}{c}\text { Aquatic-life } \\
\text { water standard } \\
\text { (freshwater) }\end{array}$} \\
\hline & & & & CMC & CCC \\
\hline Arsenic (As) & $\mu \mathrm{g} / \mathrm{L}$ & 10 & NA & 340 & 150 \\
\hline Chloride (Cl) & $\mathrm{mg} / \mathrm{L}$ & NA & 250 & 860 & 230 \\
\hline Fluoride (F) & $\mathrm{mg} / \mathrm{L}$ & 4 & 2 & NA & NA \\
\hline Iron $(\mathrm{Fe})$ & $\mu \mathrm{g} / \mathrm{L}$ & NA & 300 & NA & 1,000 \\
\hline Manganese (Mn) & $\mu \mathrm{g} / \mathrm{L}$ & NA & 50 & NA & NA \\
\hline Nitrate as $\mathrm{N}\left(\mathrm{NO}_{3}\right)$ & $\mathrm{mg} / \mathrm{L}$ & 10 & NA & NA & NA \\
\hline Nitrite as $\mathrm{N}\left(\mathrm{NO}_{2}\right)$ & $\mathrm{mg} / \mathrm{L}$ & 1 & NA & NA & NA \\
\hline $\mathrm{pH}$ & Unitless & NA & $6.5-8.5$ & NA & $6.5-9$ \\
\hline Sulfate $\left(\mathrm{SO}_{4}\right)$ & $\mathrm{mg} / \mathrm{L}$ & NA & 250 & NA & NA \\
\hline Total dissolved solids (TDS) & $\mathrm{mg} / \mathrm{L}$ & NA & 500 & NA & NA \\
\hline
\end{tabular}

Table 2. U.S. Environmental Protection Agency $(2019 a, b)$ water-quality standards for drinking water.

[Values presented in units used in this report. MCL, maximum contaminant level; SMCL, secondary maximum contaminant level; CMC, criteria maximum concentration (acute); CCC, criterion continuous concentration (chronic); $\mu \mathrm{g} / \mathrm{L}$, micrograms per liter; NA, not available; mg/L, milligrams per liter] 
Water table temperatures, and thus, recharge temperatures, for typical depths below ground surface of 5 to $50 \mathrm{~m}$ are generally 0 to $3{ }^{\circ} \mathrm{C}$ above $\mathrm{Ta}$ (Domenico and Schwartz, 1990; Lee and Hahn, 2006; Cey, 2009). Noble gas recharge temperatures were computed for groundwater samples with good CE model fits using $\mathrm{Ne}, \mathrm{Ar}, \mathrm{Kr}$, and $\mathrm{Xe}$ and for samples with reasonable recharge temperatures less than $21^{\circ} \mathrm{C}$. Uncertainties are generally between 0.5 and $1.5^{\circ} \mathrm{C}$ (Manning, 2009).

\section{Geochemical Analysis of Water Resources in the Big Chino Subbasin}

Groundwater samples were collected from 11 wells completed in basin-fill (including unconsolidated sediment and basalt), 9 wells completed in Paleozoic carbonate rock units, and 4 spring locations (fig. 2, table 1) between 2011 and 2018. Five newly installed monitoring wells (sites $12,13,15$, 17, and 19) were sampled in 2018 and include the first known geochemical data for carbonate groundwater beneath the basin-fill in the Big Chino subbasin downgradient from Walnut Creek near Paulden as well as other areas in the study without previous data. Geochemical results are presented in appendix 1 and are also available from the USGS National Water Information System database (U.S. Geological Survey, 2019) using the USGS site identifiers listed in table 1.

\section{Quality Assessment}

Field blank results indicate a low potential for contamination for the majority of analytes in this study (table 3). The two analytes with results above the laboratory reporting level and with potential for contamination were ammonia and manganese. All of the environmental results for ammonia were less than 10 times the field blank value. The field blank ammonia concentrations were at or slightly above the laboratory reporting level of 0.01 milligrams per liter $(\mathrm{mg} / \mathrm{L})$. Low-level ammonia detections have been identified in large-scale USGS studies, which indicate that the field procedures were not the source of contamination (Mueller and Titus, 2005). Manganese concentration was 1.05 micrograms per liter $(\mu \mathrm{g} / \mathrm{L})$ in the field blank from 2018, and 80 percent of the environmental samples were less than 10 times the field blank value and may be biased high.

Replicate results indicate low variability with a 3 relative percent difference, on average, between the environmental and replicate samples (table 4). Replicate variability for stable isotopes was analyzed by Beisner and others (2016) for samples analyzed at the UA Environmental Isotope Laboratory and the RSIL. The replicate variability was similar to the variability of samples analyzed at both the UA and RSIL of \pm 0.26 and \pm 1.30 per mil for $\delta^{18} \mathrm{O}$ and $\delta^{2} \mathrm{H}$, respectively, and similar for variability of replicates analyzed at $\mathrm{RSIL} \pm 0.22$ and \pm 1.56 per mil (Beisner and others, 2016).

$$
\mathrm{RPD}=\left|\frac{\text { environmental }- \text { replicate }}{\left(\frac{\text { environmental }+ \text { replicate }}{2}\right)}\right| \times 100
$$

where

$\mathrm{RPD}$ is relative percent difference

\section{Groundwater Geochemistry}

Groundwater geochemistry is described in this section for general chemistry properties, strontium and stable isotopes, noble gases, and groundwater age. The results of multivariate analyses are used to determine the variation between groundwater at different sites when including different analytes. The geochemistry results from this study are compared to those of previous studies.

\section{General Chemistry}

Water chemistry properties were measured in the field for water temperature, $\mathrm{pH}$, specific conductance, dissolved oxygen, and oxidation reduction potential (from wells sampled after 2015). Water temperature, $\mathrm{pH}$, and specific conductance were significantly different between the basin-fill aquifer and carbonate aquifer samples at the $\mathrm{p}<0.05$ threshold using the Wilcoxon rank-sum test (fig. 6). Temperature and specific conductance were higher, and $\mathrm{pH}$ was lower, in the carbonate aquifer samples compared to the basin-fill aquifer samples.

Major ion proportion indicates the dominant water type for groundwater samples, as shown on the Piper plot (fig. 7; Piper, 1944). The dominant anion was bicarbonate for all but one sample, collected at site 3 . This sample had a mixture of bicarbonate and chloride anions and the site is located next to a recharge basin. The dominant cation varied between calcium-, sodium-, and mixed-type waters. Two samples from carbonate aquifer wells (sites 19 and 20) were sodium-type water, which may be old water that has undergone cation exchange. One sample from a basin-fill aquifer well (site 8) was also sodium-type water. The well is completed in basalt and the water shows evidence of interaction with carbonate; thus, it may also be old water that has undergone cation exchange. Samples from two basin-fill aquifer wells (sites 1 and 2) were calcium-type water that may be young. Both wells are located near Williamson Valley Wash on the south side of the study area. One sample from a basin-fill aquifer well (site 7) plots near the carbonate aquifer samples that show a mixture of dominant cation. The site 7 well is completed in the basin-fill aquifer but is located close to the mountain front. Samples from the springs plot within the group of samples from carbonate aquifer wells.

Site 8 water exceeded the EPA maximum contaminant level (MCL) of $4 \mathrm{mg} / \mathrm{L}$ for fluoride in drinking water. Site 19 water exceeded the EPA secondary maximum contaminant 
Table 3. Results of field blank analysis.

[Dates shown as month, day, year; times shown in 24-hour format. $\mu \mathrm{S} / \mathrm{cm}$ at $25{ }^{\circ} \mathrm{C}$, microsiemens per centimeter at 25 degrees Celsius; mg/L, milligrams per liter; $\mu \mathrm{g} / \mathrm{L}$, micrograms per liter; $\mathrm{N}$, nitrogen; $\mathrm{P}$, phosphorus; $\mathrm{CaCO}_{3}$, calcium carbonate; $<$, less than]

\begin{tabular}{|c|c|c|c|}
\hline \multirow{3}{*}{ Analyte } & \multirow{3}{*}{ Units } & \multicolumn{2}{|c|}{ Result } \\
\hline & & Site 1 & Site 19 \\
\hline & & $\begin{array}{c}8 / 24 / 2017, \\
0900 \text { hours }\end{array}$ & $\begin{array}{c}6 / 13 / 2018 \text {, } \\
0900 \text { hours }\end{array}$ \\
\hline Specific conductance, field & $\mu \mathrm{S} / \mathrm{cm}$ at $25^{\circ} \mathrm{C}$ & 2.4 & 3.3 \\
\hline Specific conductance, lab & $\mu \mathrm{S} / \mathrm{cm}$ at $25^{\circ} \mathrm{C}$ & $<5$ & $<5$ \\
\hline Ammonia $\left(\mathrm{NH}_{3}+\mathrm{NH}_{4}^{+}\right)$ & $\mathrm{mg} / \mathrm{L}$ as $\mathrm{N}$ & 0.010 & 0.011 \\
\hline Nitrite & $\mathrm{mg} / \mathrm{L}$ as $\mathrm{N}$ & $<0.001$ & $<0.001$ \\
\hline Nitrate plus nitrite & $\mathrm{mg} / \mathrm{L}$ as $\mathrm{N}$ & $<0.04$ & $<0.04$ \\
\hline Orthophosphate & $\mathrm{mg} / \mathrm{L}$ as $\mathrm{P}$ & $<0.004$ & $<0.004$ \\
\hline Calcium & $\mathrm{mg} / \mathrm{L}$ & $<0.022$ & $<0.022$ \\
\hline Magnesium & $\mathrm{mg} / \mathrm{L}$ & $<0.011$ & $<0.011$ \\
\hline Sodium & $\mathrm{mg} / \mathrm{L}$ & $<0.1$ & $<0.1$ \\
\hline Potassium & $\mathrm{mg} / \mathrm{L}$ & $<0.1$ & $<0.3$ \\
\hline Chloride & $\mathrm{mg} / \mathrm{L}$ & $<0.02$ & $<0.02$ \\
\hline Sulfate & $\mathrm{mg} / \mathrm{L}$ & $<0.02$ & $<0.02$ \\
\hline Fluoride & $\mathrm{mg} / \mathrm{L}$ & $<0.01$ & $<0.01$ \\
\hline Silica & $\mathrm{mg} / \mathrm{L}$ as $\mathrm{SiO}_{2}$ & $<0.06$ & $<0.06$ \\
\hline Arsenic & $\mu \mathrm{g} / \mathrm{L}$ & $<0.05$ & $<0.1$ \\
\hline Iron & $\mu \mathrm{g} / \mathrm{L}$ & $<10$ & $<10$ \\
\hline Manganese & $\mu \mathrm{g} / \mathrm{L}$ & $<0.2$ & 1.05 \\
\hline Acid neutralizing capacity & $\mathrm{mg} / \mathrm{L}$ as $\mathrm{CaCO}_{3}$ & $<4$ & $<4$ \\
\hline
\end{tabular}

level of $2 \mathrm{mg} / \mathrm{L}$ for fluoride in drinking water (fig. 8). Both sites are monitoring wells and are not currently used for drinking water supply. Fluoride concentration was higher in carbonate groundwater than in basin-fill groundwater (Wilcoxon rank sum, $\mathrm{W}=22$ and $\mathrm{p}=0.004$ ) with a median of $0.72 \mathrm{mg} / \mathrm{L}$ for carbonate and $0.31 \mathrm{mg} / \mathrm{L}$ for basin-fill (fig. 8).

Water from 13 of 22 groundwater sites sampled for this study exceeded the EPA MCL for arsenic of $10 \mu \mathrm{g} / \mathrm{L}$ (fig. 9). Water from all but one groundwater well completed in carbonate units exceeded the EPA MCL for arsenic. Arsenic concentration was higher in wells completed in the carbonate aquifer than in wells completed in the basin-fill aquifer (Wilcoxon rank sum, $\mathrm{W}=11.5$ and $\mathrm{p}=0.004$ ) with a median of $37 \mu \mathrm{g} / \mathrm{L}$ for the carbonate aquifer and $4.3 \mu \mathrm{g} / \mathrm{L}$ for the basin-fill aquifer (fig. 10).

Total dissolved solids exceeded the EPA secondary maximum contaminant level of $500 \mathrm{mg} / \mathrm{L}$ at eight groundwater wells (sites 7, 8, 13, 14, 16, 18, 19, and 20). Three samples (both samples from site 8 and one sample from site 21 in 2018) had manganese values greater than the EPA secondary drinking water standard of $50 \mu \mathrm{g} / \mathrm{L}$. Nutrients measured in samples collected in 2017 and 2018 were low for groundwaters in the study area compared to the EPA drinking water standards (table 2). Most ammonia and nitrogen $(\mathrm{N})$ concentrations were less than the laboratory reporting level of $0.01 \mathrm{mg} / \mathrm{L}$. Two low-level values of 0.01 and 0.02 were reported for UVS South (site 21) and Greenbie Pool (site 22) springs in 2018. Low-level ammonia detections have been documented in field blanks collected during this study, as well as in previous efforts by the USGS, that are in the concentration range of the low detections in this study (Mueller and Titus, 2005). Nitrite as $\mathrm{N}$ concentration was low with the majority of samples less than $0.001 \mathrm{mg} / \mathrm{L}$; concentrations in other samples ranged from 0.001 to $0.004 \mathrm{mg} / \mathrm{L}$. Nitrate as $\mathrm{N}$ concentrations ranged from 0.956 to $5.05 \mathrm{mg} / \mathrm{L}$ with all but two samples less than $2 \mathrm{mg} / \mathrm{L}$. The EPA drinking water standard (MCL) for nitrate as $\mathrm{N}$ is $10 \mathrm{mg} / \mathrm{L}$ (table 2). Orthophosphate as phosphate concentrations ranged from 0.013 to $0.077 \mathrm{mg} / \mathrm{L}$.

\section{Isotopic Analyses}

Geochemistry results for isotopic analyses are presented for strontium isotopes of ${ }^{87} \mathrm{Sr}$ and ${ }^{86} \mathrm{Sr}$ and for stable isotopes of oxygen $\left(\delta^{18} \mathrm{O}\right)$ and hydrogen $\left(\delta^{2} \mathrm{H}\right)$. 
Table 4. Replicate sample data for groundwater samples.

[Dates shown as month, day, year. $\mu \mathrm{s} / \mathrm{cm}$ at $25^{\circ} \mathrm{C}$, microsiemens per centimeter at 25 degrees Celsius; $\mathrm{mg} / \mathrm{L}$, milligrams per liter; $\mu \mathrm{g} / \mathrm{L}$, micrograms per liter; $\mathrm{N}$, nitrogen; P, phosphorus; $\mathrm{CaCO}_{3}$, calcium carbonate; $\mathrm{pCi} / \mathrm{L}$, picocuries per liter; R, radiochemistry non-detect; pmc, percent modern carbon; nc, not calculated; <, less than]

\begin{tabular}{|c|c|c|c|c|c|c|c|}
\hline \multirow[b]{2}{*}{ Analyte } & \multirow[b]{2}{*}{ Units } & \multicolumn{3}{|c|}{ Site 3 (sampled 8/23/17) } & \multicolumn{3}{|c|}{ Site 13 (sampled 2/21/18) } \\
\hline & & $\begin{array}{l}\text { Environmental } \\
\text { sample }\end{array}$ & $\begin{array}{l}\text { Replicate } \\
\text { sample }\end{array}$ & $\begin{array}{c}\text { Relative } \\
\text { percent } \\
\text { difference }\end{array}$ & $\begin{array}{l}\text { Environmental } \\
\text { sample }\end{array}$ & $\begin{array}{l}\text { Replicate } \\
\text { sample }\end{array}$ & $\begin{array}{l}\text { Relative } \\
\text { percent } \\
\text { difference }\end{array}$ \\
\hline $\begin{array}{l}\text { Specific conductance, } \\
\text { lab }\end{array}$ & $\begin{array}{c}\mu \mathrm{S} / \mathrm{cm} \text { at } \\
25^{\circ} \mathrm{C}\end{array}$ & 512 & 512 & 0 & 805 & 807 & 0 \\
\hline $\mathrm{pH}, \mathrm{lab}$ & $\begin{array}{l}\text { Standard } \\
\text { units }\end{array}$ & 8.1 & 8.11 & 0 & 7.9 & 7.85 & 1 \\
\hline $\begin{array}{l}\text { Ammonia }\left(\mathrm{NH}_{3}+\right. \\
\left.\qquad \mathrm{NH}_{4}^{+}\right)\end{array}$ & $\mathrm{mg} / \mathrm{L}$ as $\mathrm{N}$ & $<0.01$ & $<0.01$ & $\mathrm{nc}$ & $<0.01$ & $<0.01$ & \\
\hline Nitrite & $\mathrm{mg} / \mathrm{L}$ as $\mathrm{N}$ & $<0.001$ & $<0.001$ & $\mathrm{nc}$ & 0.001 & 0.001 & 0 \\
\hline Nitrate plus nitrite & $\mathrm{mg} / \mathrm{L}$ as $\mathrm{N}$ & 5.05 & 5.07 & 0 & 1.35 & 1.34 & 1 \\
\hline Orthophosphate & $\mathrm{mg} / \mathrm{L}$ as $\mathrm{P}$ & 0.013 & 0.014 & 7 & 0.026 & 0.025 & 3 \\
\hline Calcium & $\mathrm{mg} / \mathrm{L}$ & 38.8 & 38.6 & 1 & 58.4 & 58.1 & 1 \\
\hline Magnesium & $\mathrm{mg} / \mathrm{L}$ & 22 & 21.8 & 1 & 29.6 & 29.5 & 0 \\
\hline Sodium & $\mathrm{mg} / \mathrm{L}$ & 29 & 29.1 & 0 & 89.2 & 88.8 & 0 \\
\hline Potassium & $\mathrm{mg} / \mathrm{L}$ & 1.82 & 1.81 & 1 & 3.56 & 3.58 & 1 \\
\hline Chloride & $\mathrm{mg} / \mathrm{L}$ & 47 & 47 & 0 & 28.2 & 28.9 & 3 \\
\hline Sulfate & $\mathrm{mg} / \mathrm{L}$ & 42.8 & 42.8 & 0 & 22.9 & 23.3 & 2 \\
\hline Sulfide & $\mathrm{mg} / \mathrm{L}$ & $<0.1000$ & $<0.1$ & $\mathrm{nc}$ & $<0.1000$ & $<0.1$ & $\mathrm{nc}$ \\
\hline Fluoride & $\mathrm{mg} / \mathrm{L}$ & 0.24 & 0.24 & 0 & 0.72 & 0.75 & 4 \\
\hline Strontium & $\mu \mathrm{g} / \mathrm{L}$ & 529 & 538 & 2 & 280 & 267 & 5 \\
\hline Tritium & $\mathrm{pCi} / \mathrm{L}$ & 1.69 & 1.93 & 13 & R 0.03 & R 0.1 & $\mathrm{nc}$ \\
\hline Carbon-14 & Pmc & 67.98 & 66.5 & 2 & 18.69 & 18.58 & 1 \\
\hline${ }^{87} \mathrm{Sr} / 86 \mathrm{Sr}$ & Unitless & 0.70769 & 0.70782 & 0 & 0.71128 & 0.711312 & 0 \\
\hline$\delta^{13} \mathrm{C}$ & Per mil & -9 & -10.54 & 16 & -6.2 & -6.17 & 0 \\
\hline$\delta^{2} \mathrm{H}$ & Per mil & -67.1 & -66.6 & 1 & -75.7 & -76.9 & 2 \\
\hline$\delta^{18} \mathrm{O}$ & Per mil & -9.02 & -9.12 & 1 & -10.46 & -10.44 & 0 \\
\hline $222 \mathrm{Rn}$ & $\mathrm{pCi} / \mathrm{L}$ & 720 & 664 & 8 & 144 & 157 & 9 \\
\hline
\end{tabular}



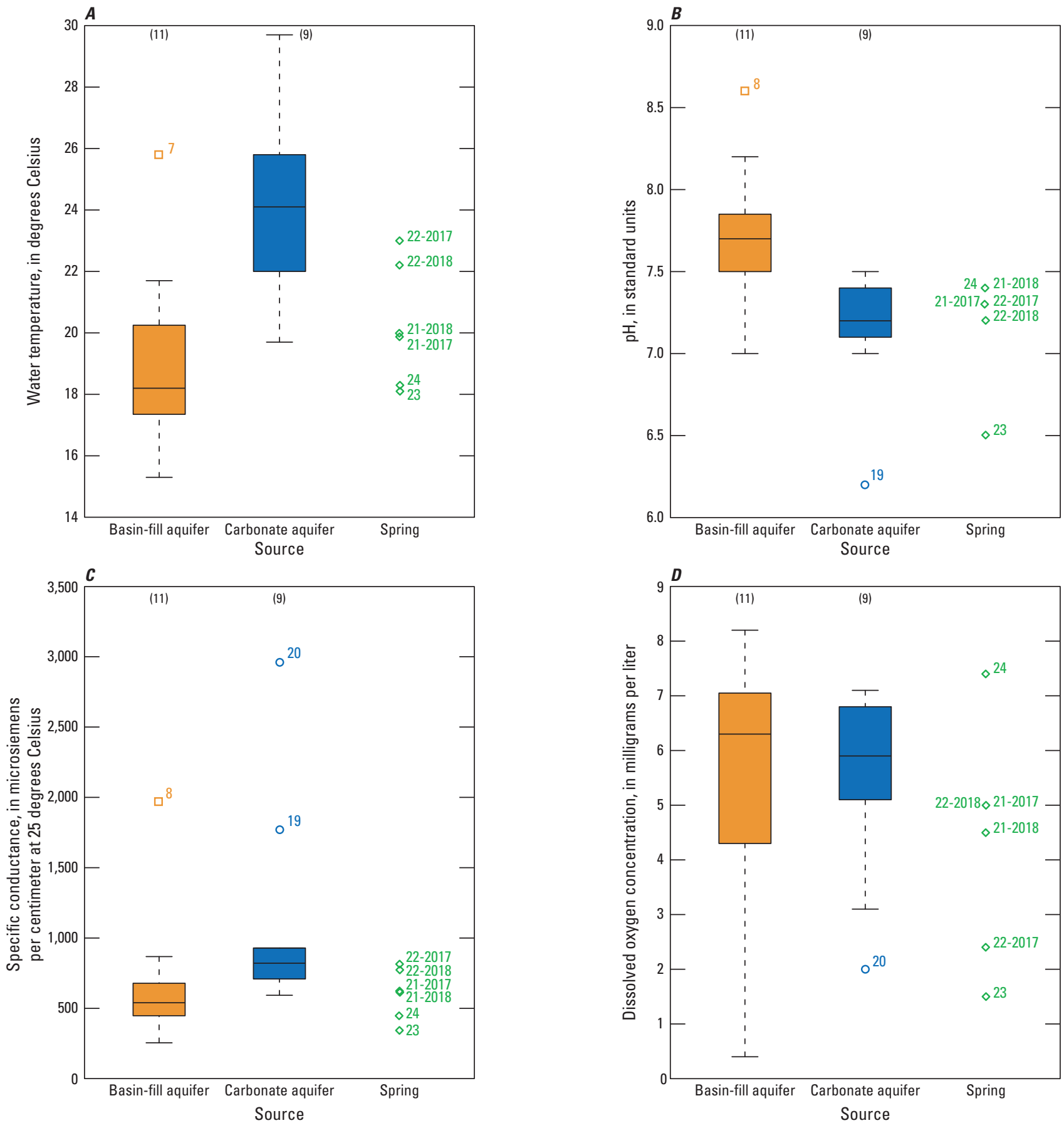

\section{EXPLANATION}

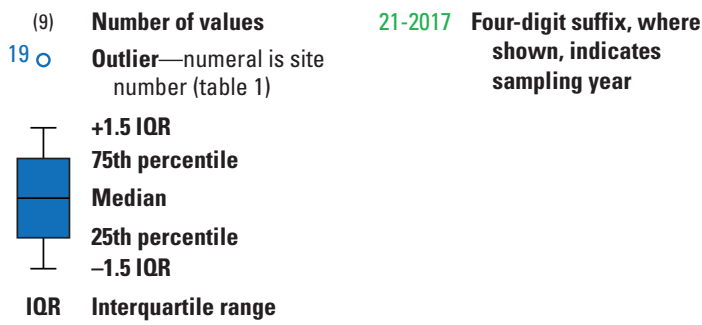

Figure 6. Boxplots of selected water chemistry properties, categorized by source. $A$, water temperature; $B, \mathrm{pH} ; C$, specific conductance; and $D$, dissolved oxygen concentration. Symbols in the spring column are data points but not outliers, because there were not enough data points to construct boxplots. 


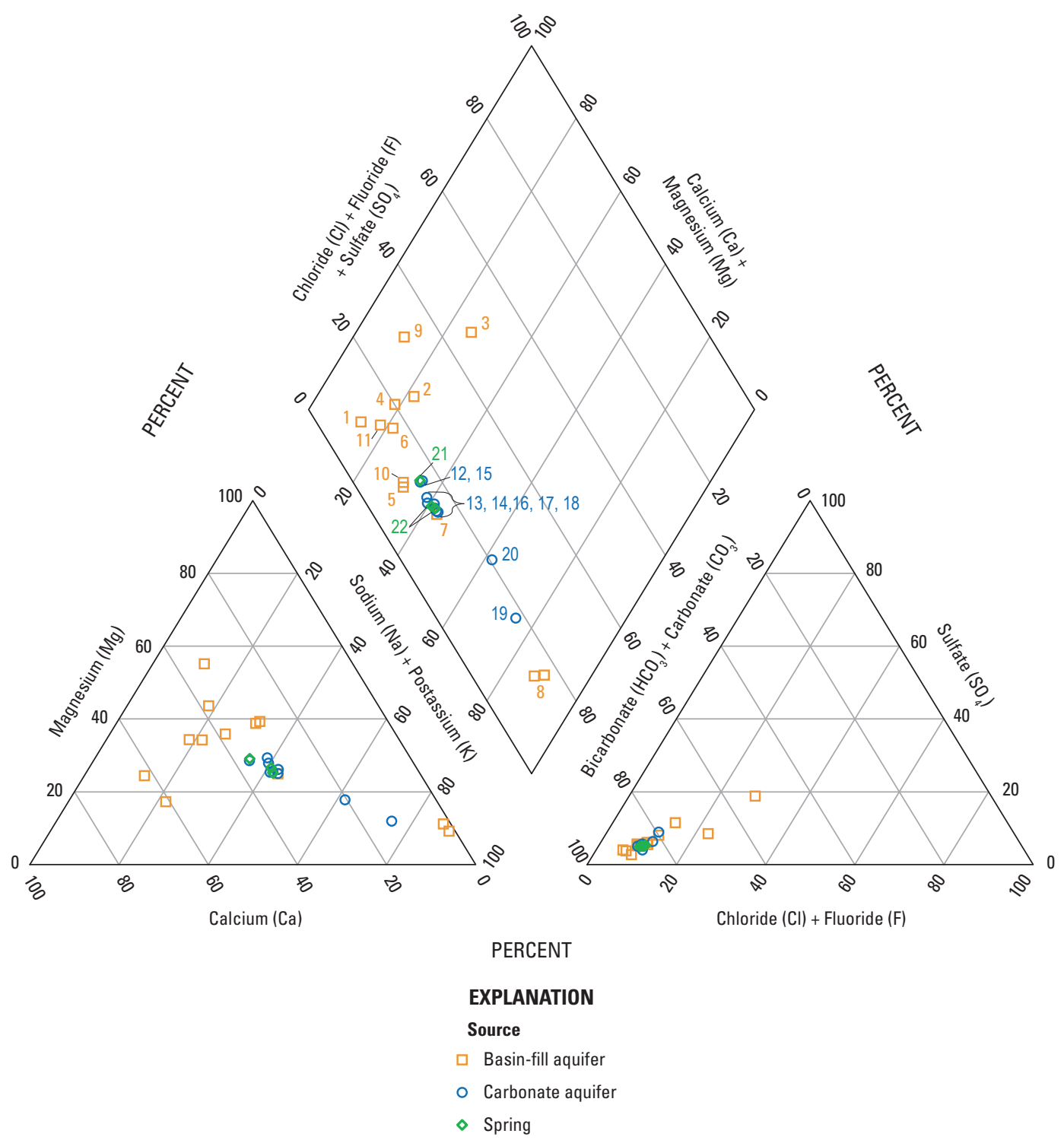

Figure 7. Major ion composition of groundwater samples. All axes plot relative concentrations. Numerals beside symbols are the site numbers. Site names are presented in table 1.

\section{Strontium Isotopes}

The ratio of strontium isotopes ${ }^{87} \mathrm{Sr}$ and ${ }^{86} \mathrm{Sr}$ ranged from 0.70702 to 0.71824 , and the strontium concentration ranged from 160 to $600 \mu \mathrm{g} / \mathrm{L}$ (fig. 11). Groundwater from the carbonate aquifer was more radiogenic, with a median of 0.71121 , compared to groundwater from the basin-fill aquifer, with a median of 0.70926 (Wilcoxon rank sum $p<0.005$ ). Median strontium concentrations in groundwater from the carbonate aquifer $(307 \mu \mathrm{g} / \mathrm{L})$ were slightly less than in groundwater from the basin-fill aquifer $(344 \mu \mathrm{g} / \mathrm{L})$, but the groups were not significantly different (Wilcoxon rank sum $\mathrm{p}=0.78$ ). UVS South (site 21) and Greenbie Pool (site 22) had intermediate strontium isotopic values $(0.7102$ and 0.7109 , respectively) among those for the dataset of this study. Cabin
Spring (site 23) and Duff Spring (site 24) were not sampled for strontium isotopes as part of this study, but previous studies reported a radiogenic isotope value of 0.72466 for Cabin Spring in 2001 and 0.70823 for Duff Spring in 2000. (Other analyte results from these samples are available in Wirt and DeWitt [2005] and strontium isotopic values are available in U.S. Geological Survey [2019].)

Tertiary volcanic rocks, including basalt, have the lowest measured strontium isotopic values in the area (0.70463 to 0.70603; Bills and others, 2007; Beisner and others, 2019). Paleozoic sedimentary rocks have intermediate strontium isotopic values (0.70756 to 0.71215; Bills and others, 2007; Beisner and others, 2019). Proterozoic igneous rocks have the highest strontium isotopic values (0.71618 to 0.877889 ; Bills 


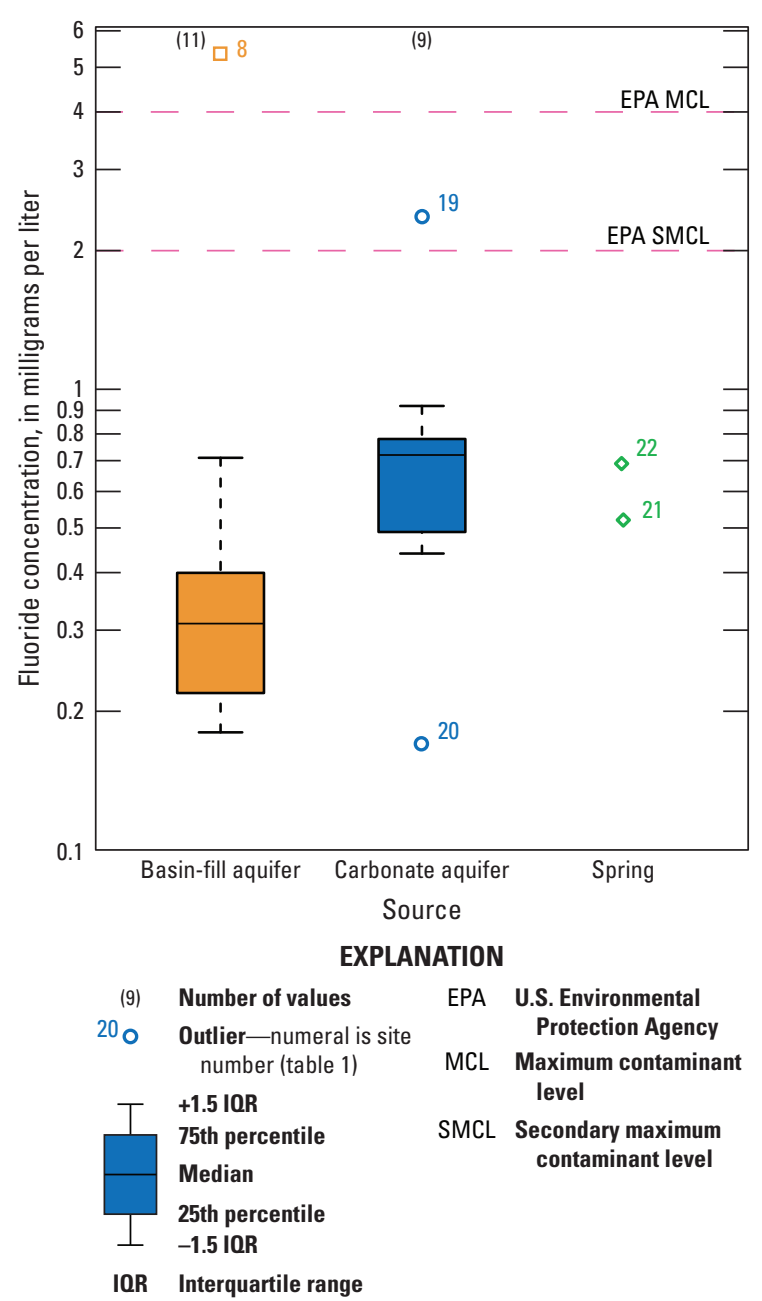

Figure 8. Boxplot of fluoride concentrations categorized by source. Symbols in the spring column are data points but not outliers because there were not enough data points to construct boxplots.

and others, 2007; Beisner and others, 2019). Precipitation strontium isotopic values have been reported to range from 0.7098 to 0.7107 (Frost and Toner, 2004).

The strontium isotopic value for site 2 is higher than those for other wells completed in the basin-fill aquifer. Site 2 is located near Williamson Valley Wash, which drains from granitic mountains. Additionally, samples from the basin-fill aquifer with elevated strontium isotopic values of 0.71029 and 0.71097 were collected at sites 1 and 7 respectively, which are located on the margins of the basin-fill areas where Tertiary volcanic rock is present at isolated locations. Site 8, sampled twice during this study, has the lowest strontium isotopic values $(0.70702$ and 0.70721$)$, which are below the range for Paleozoic sedimentary rocks (fig. 11). This well is completed in basalt, and the values obtained may indicate a component of water has interacted with volcanic rock and Paleozoic sedimentary rocks.
Well 4e (site 12) has the lowest strontium isotopic value for wells completed in the carbonate aquifer (0.7101, fig. 11), which is similar to the strontium isotopic value for groundwater sampled from a piezometer on the north bank of the Verde River (0.70971). Site 12 is located just north of the Verde River (fig. 4) and is drilled through Tertiary volcanic rocks above the Paleozoic sedimentary rocks it is completed in. The most radiogenic groundwater sample from this study (0.71824) was from site 20 (fig. 11), which is completed in Paleozoic carbonate rocks and may represent a component of water in contact with deeper Proterozoic rocks or local deviations within the Paleozoic carbonate rock.

\section{Stable Isotopes}

Stable isotopes of oxygen $\left(\delta^{18} \mathrm{O}\right)$ and hydrogen $\left(\delta^{2} \mathrm{H}\right)$ in groundwater from the study area ranged from -8.76 to -11.3 per mil and from -64.6 to -83.2 per mil for $\delta^{18} \mathrm{O}$ and $\delta^{2} \mathrm{H}$ (figs. 12 and 13). The most depleted values were from groundwater in the highest elevations of the study area, specifically to the northeast and southwest of Big Chino Wash (fig. 12). The most enriched (least negative) values were measured in samples collected in basin-fill at the southern end of the study area, Duff Spring (site 24), a well screened in basalt just north of Sullivan Lake (site 4), a well screened in basin-fill (site 3), and the Stringtown Wash site (which may represent summer recharge in a localized area). Samples from four wells screened in the carbonate aquifer (sites 16, 18, 19, and 20) have more depleted (more negative) values than those from the other carbonate aquifer wells.

Groundwater from the carbonate aquifer was depleted compared with groundwater from the basin-fill aquifer (Wilcoxon rank sum $\mathrm{p}<0.0005$ ) with an average of -10.6 and -77.6 (carbonate) and -9.79 and -71.6 (basin-fill) for $\delta^{18} \mathrm{O}$ and $\delta^{2} \mathrm{H}$, respectively. Cabin Spring (site 23) is located in the Santa Maria Mountains and had depleted stable isotopic values of -11.3 and -78 per mil for $\delta^{18} \mathrm{O}$ and $\delta^{2} \mathrm{H}$, respectively, whereas Duff Spring (24) had an enriched (less negative) stable isotopic values of -9.2 and -70 per mil for $\delta^{18} \mathrm{O}$ and $\delta^{2} \mathrm{H}$, respectively. Two springs located along the gaining reach of the Verde River below Granite Creek, UVS South (site 21) and Greenbie Pool (site 22), have stable isotopic values in the middle of the range of those for groundwater samples, ranging from -10.2 to -10.33 per mil for $\delta^{18} \mathrm{O}$ and from -74.5 to -76 per mil for $\delta^{2} \mathrm{H}$ (fig. 13).

Generally, stable isotope values decrease with increasing elevation, with a change of -0.5 and -0.07 per $100 \mathrm{ft}$ of elevation increase for $\delta^{2} \mathrm{H}$ and $\delta^{18} \mathrm{O}$, respectively (Blasch and others, 2006). The observed decrease was smaller in Beisner and others (2016), with -0.29 and -0.04 per $100 \mathrm{ft}$ of elevation increase for $\delta^{2} \mathrm{H}$ and $\delta^{18} \mathrm{O}$, respectively. That study used weighted average values from winter precipitation sampled between Camp Verde and Flagstaff at 3,100 and 8,100 ft elevations at the same sites used by Blasch and others (2006) over a longer period of time. Additionally, for winter precipitation samples collected from Prescott to Big Chino Valley, 


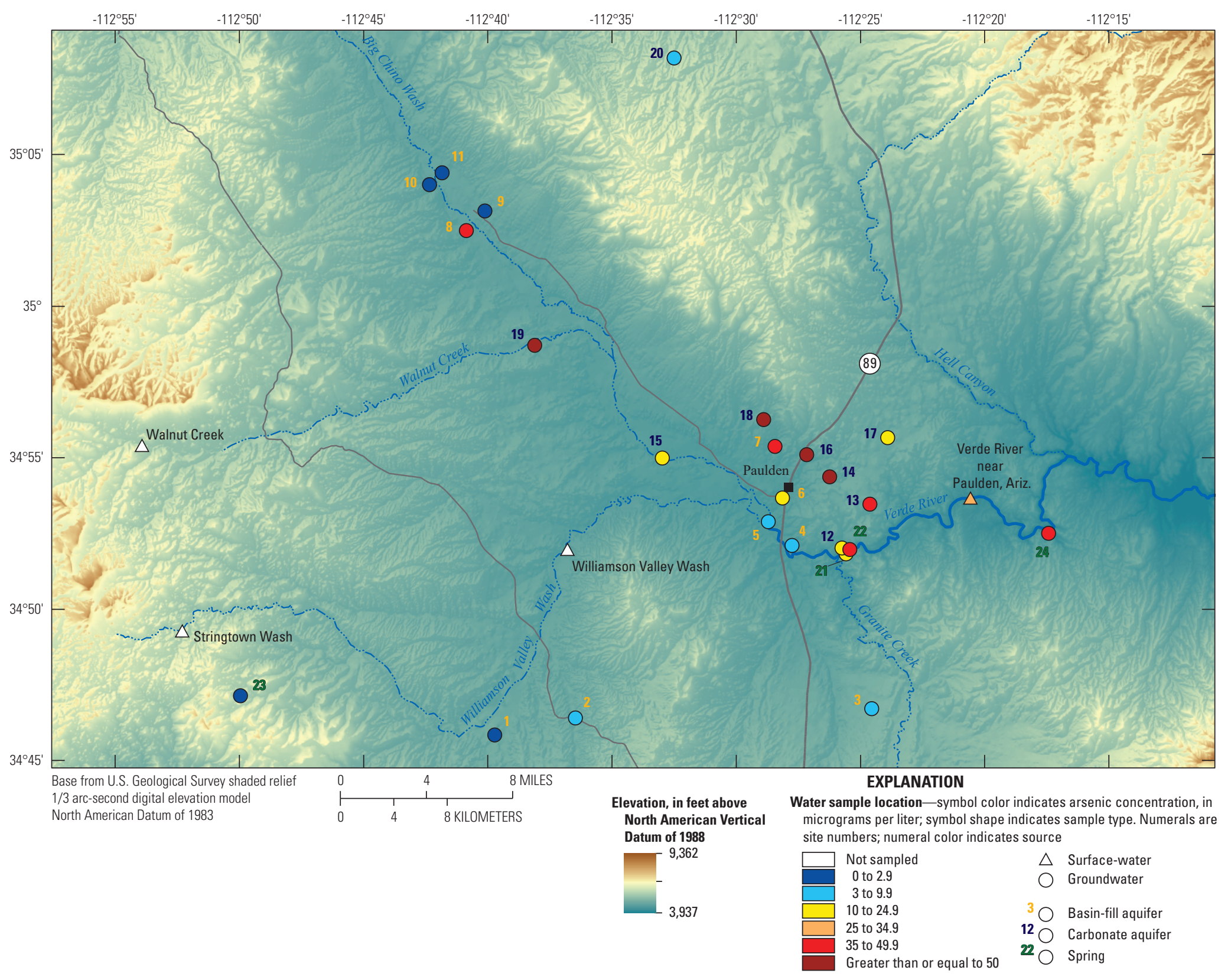

Figure 9. Arsenic concentrations in the study area. Site names are presented in table 1. 


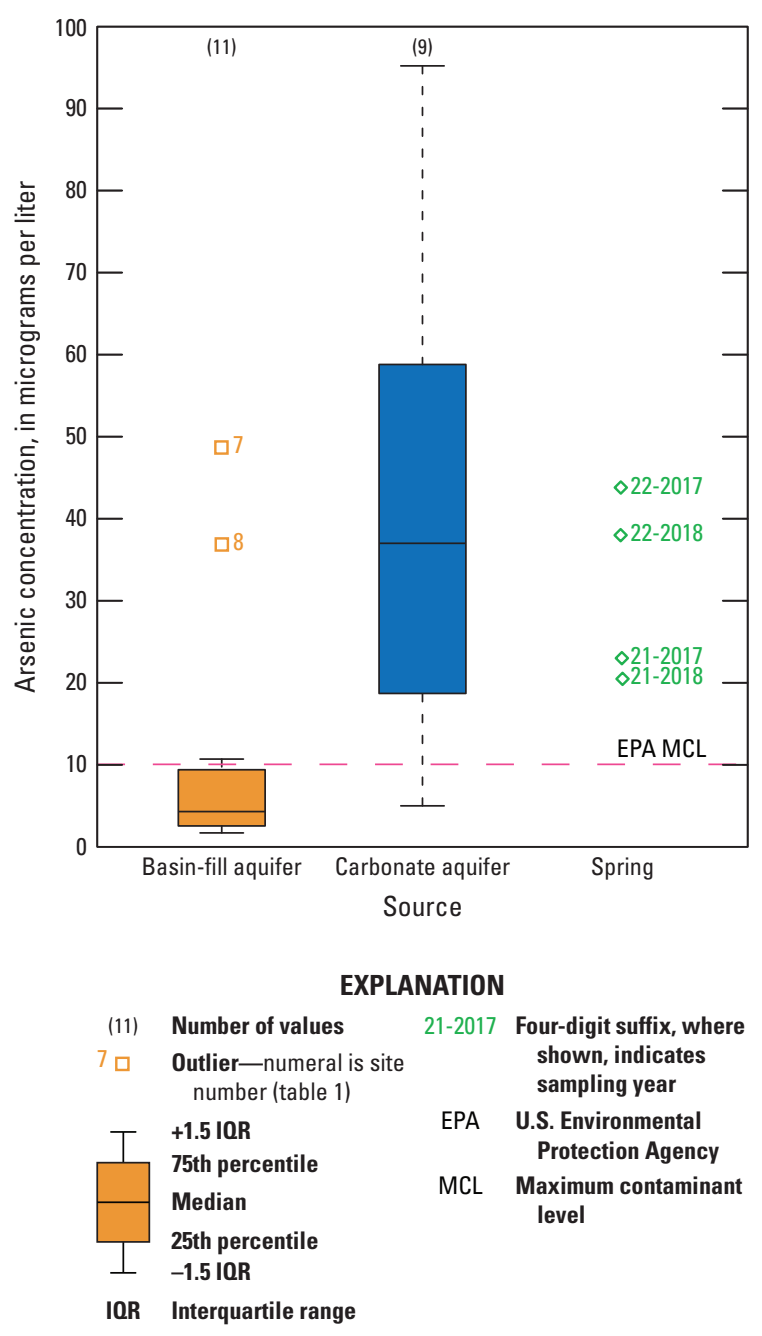

Figure 10. Boxplot of arsenic concentrations categorized by source. Symbols in the spring column are data points but not outliers because there were not enough data points to construct boxplots.

stable isotopic values did not show a decrease with elevation between 4,600 and 7,600 ft (weighted values of approximately -76.4 and -11.2 for $\delta^{2} \mathrm{H}$ and $\delta^{18} \mathrm{O}$, respectively) (Beisner and others, 2016). Summer precipitation samples along this transect did show a decrease in stable isotopic values with increasing elevation of similar magnitude, with a change of -0.22 and -0.05 per $100 \mathrm{ft}$ of elevation increase for $\delta^{2} \mathrm{H}$ and $\delta 18 \mathrm{O}$, respectively, to the winter decrease between Camp Verde and Flagstaff (Beisner and others, 2016). This may be due to storm path dynamics that affect a localized area.

The stable isotopic values of $\delta 18 \mathrm{O}$ from groundwater in the study area are all greater than -11.3 per mil (fig. 13). This finding may indicate that the groundwater has a component of summer or winter recharge from other higher locations in the study area where the winter recharge follows a similar decrease with elevation of stable isotopic values that has not been measured. Stable isotopic ratios of $\delta^{2} \mathrm{H}$ are lower than the winter threshold of -76.4 per mil for Cabin Spring (site 23) and all but three samples from the carbonate aquifer (sites 12 , 13, and 15). The groundwater samples (except for Cabin Spring [site 23]) plot to the right of the local meteoric water line and global meteoric water line (GMWL) (fig. 13) and may indicate a small amount of evaporation, as the precipitation fell before recharge or within the unsaturated zone, that is not represented in the precipitation samples from Beisner and others (2016).

\section{Noble Gases}

Noble gas samples were collected from groundwater samples and represent a more direct measurement of recharge temperature and elevation compared with stable isotopes, as well as an indication of groundwater evolution. The concentration of He was highest - as much as four orders of magnitude greater than the lowest sample in the study area-at sites 8 , 19 , and 20 with concentrations ranging from $1.16 \mathrm{E}-04$ to 4.48E-04 ccSTP/g (table 5). These sites had some of the oldest groundwater in the study area, greater than 8,000 years old. Another group of samples had elevated He ranging from $1.16 \mathrm{E}-05$ to $6.79 \mathrm{E}-05 \mathrm{ccSTP} / \mathrm{g}$ at sites $7,8,10,12,14,15,16$, 18 , and 22. These sites had old groundwater on the order of thousands of years old. The sites with high $\mathrm{He}$ - sites 7, 8, and 10 -are primarily in the carbonate aquifer or have characteristics of water moving through carbonate prior to flowing into basin-fill material.

The $\mathrm{R} / \mathrm{Ra}$ (ratio of $3 \mathrm{He}$ to ${ }^{4} \mathrm{He}$ in the sample relative to the value in the atmosphere) and ratio of terrigenic He to total He indicate whether the source of the $\mathrm{He}$ in the water originated primarily from the atmosphere, crust, or mantle (table 5; White, 2013). The waters from this study had primarily crustal He. Six sites $(1,2,3,4,9$, and 11) completed in the basin-fill aquifer showed a strong component of atmospherically derived He, as did site 24 (Duff Spring). Site 23 (Cabin Spring) had intermediate He, derived from crustal and atmospheric sources. None of the sites sampled in this study had an appreciable component of mantle-derived fluids.

A local relation between recharge temperature and elevation can place useful constraints on recharge elevation (Zuber and others, 1995; Aeschbach-Hertig and others, 1999; Manning and Solomon, 2003). Recharge temperature and elevation computed using $\mathrm{Ne}, \mathrm{Ar}, \mathrm{Kr}$, and $\mathrm{Xe}$ are presented in table 6. CE model results for recharge temperature and elevation that cross the local recharge and temperature relation are shown in figure 14.

Three sites $(1,2$, and 23$)$ had noble gas data indicating high elevation recharge ( $>8,000 \mathrm{ft})$ (fig. 14). These sites are located at the southern end of the study area (fig. 4). The next highest recharge elevation (6,644 ft) was site 5 (fig. 14), which is completed in the basin-fill aquifer and has old water. Sites 3 and 9, both completed in the basin-fill aquifer, have an identical recharge elevation of 5,512 ft. Site 7 is also completed in the basin-fill aquifer but shows geochemical evidence of water movement and interaction with carbonate rock and has a recharge elevation of 4,921 ft. Sites 6, 15, and 21 


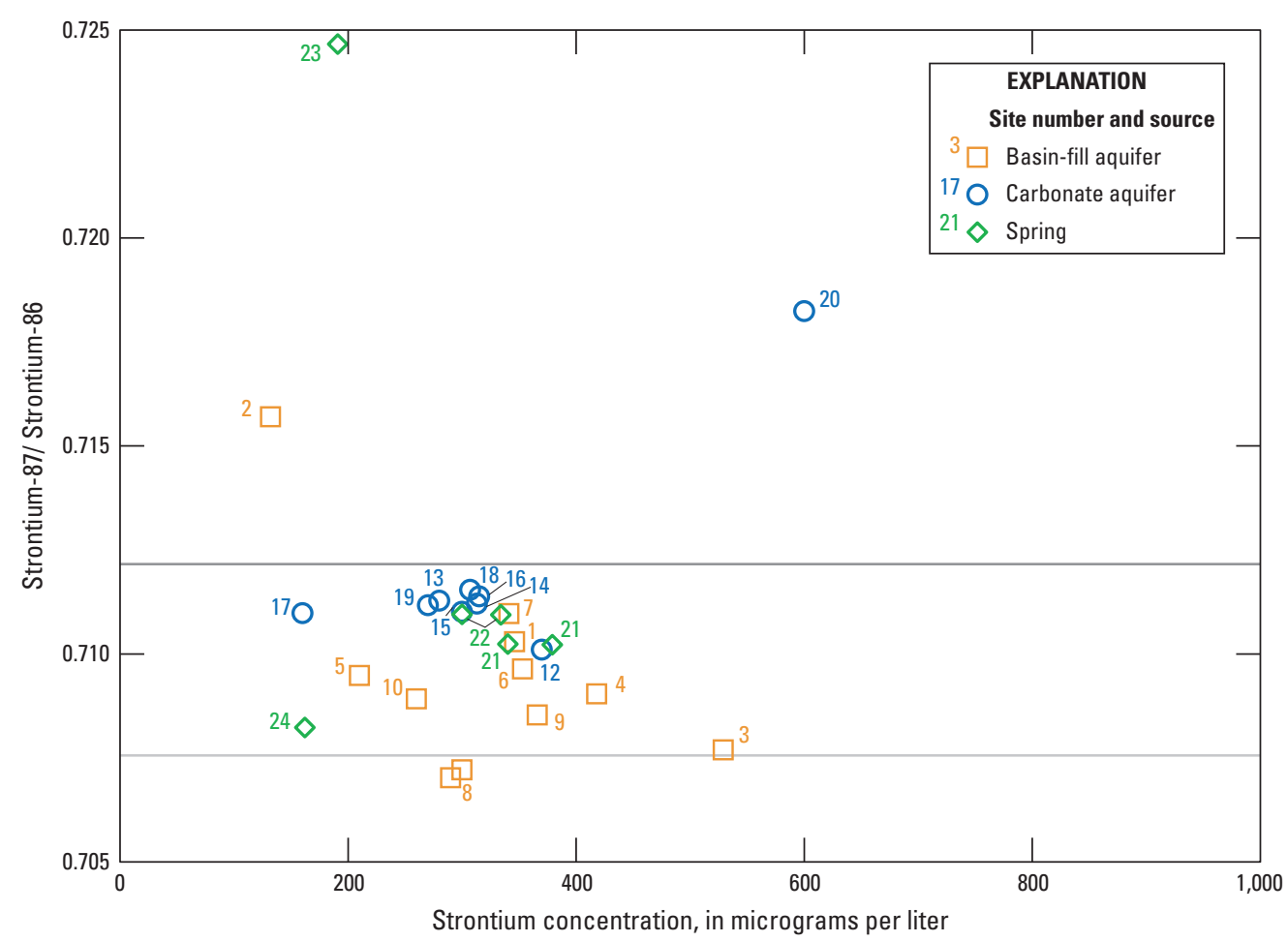

Figure 11. Strontium isotope ratio $\left({ }^{87} \mathrm{Sr} / 86 \mathrm{Sr}\right)$ versus strontium concentration for groundwater samples categorized by source. Strontium isotopic ratios for sites 23 and 24 are published in U.S. Geological Survey (2019). Solid lines represent the range in strontium isotopic values for Paleozoic sedimentary rocks (Bills and others, 2007; Beisner and others, 2019).

(from 2017) have similar recharge elevations ranging from 4,364 to $4,199 \mathrm{ft}$. The other sites $(10,12,14,16,18,21$ [2018], 22 , and 24, fig. 14, table 6) have noble gas data that when run through the CE model give recharge temperatures above the $\mathrm{Ta}+1.5$ line for elevations near the ground elevation of the site. These may have a recharge elevation slightly higher than the ground elevation of the site if the groundwater recharged at a $\mathrm{Ta}+3$ temperature, or they may represent re-equilibration near the sampling site.

Sites 6, 8, 14, 18, 19, 20, 21 and 22[2017] had high excess air values $(>0.1 \mathrm{ccSTP} / \mathrm{g})$ (table 6$)$. The groundwater at some of these sites had noticeable bubbles during sampling that were minimized when sampling for noble gases by applying back pressure. The bubbles may indicate degassing of groundwater as it is pulled up from the subsurface, however. Degassing may alter the noble gases in the water sample compared to their condition within the aquifer.

\section{Groundwater Age}

Tritium is a useful tracer for determining if there is a component of water recharged during or after the period of nuclear bomb testing in the 1950s and 1960s, when tritium in the atmosphere peaked and then decreased over the following decades. Tritium values stopped decreasing in precipitation after 1992, and average recent values of tritium in precipitation in Tucson, Ariz., are $17 \mathrm{pCi} / \mathrm{L}$ (Eastoe and others, 2012). Tritium values of samples from this study ranged from $-0.17 \mathrm{pCi} / \mathrm{L}$ (which is less than the reporting limit of $0.3 \mathrm{pCi} / \mathrm{L}$ ) to $11.4 \mathrm{pCi} / \mathrm{L}$.

A categorical classification of tritium was calculated for the Grand Canyon, where values less than $1.3 \mathrm{pCi} / \mathrm{L}$ represent premodern waters, values greater than $12.8 \mathrm{pCi} / \mathrm{L}$ represent modern water (recharged primarily after 1952), and values between these thresholds indicate a mixture of premodern and modern water (Beisner and others, 2017). The majority of the groundwater samples from this study had values less than $0.6 \mathrm{pCi} / \mathrm{L}$, including all carbonate wells and the UVS. The springs with low tritium values also have radiocarbon data indicating old water (fig. 15; table 7). The other groundwater samples, including those for sites 1, 2, 3, 4, 6, 9, 11, Cabin Spring (site 23), and Duff Spring (site 24), have tritium values greater than $1.3 \mathrm{pCi} / \mathrm{L}$ indicating a mixture of premodern and modern water (fig. 15; table 7). Groundwater with low values of tritium $(<0.6 \mathrm{pCi} / \mathrm{L})$ had carbon-14 values less than $40 \mathrm{pmc}$, while samples with higher values of tritium $(>1.3 \mathrm{pCi} / \mathrm{L})$ had carbon-14 values greater than 40 pmc (fig. 15).

The age of the fraction of young water (tritiated water) can be calculated using the tritium value and the tritiogenic ${ }^{3} \mathrm{He}$ by assuming a terrigenic $\mathrm{He}$ value of $2 \mathrm{E}-08$. Sites 1 , $2,4,9,23$, and 24, which have the highest tritium values $(>2.5 \mathrm{pCi} / \mathrm{L})$, have apparent ages of the young fraction of 


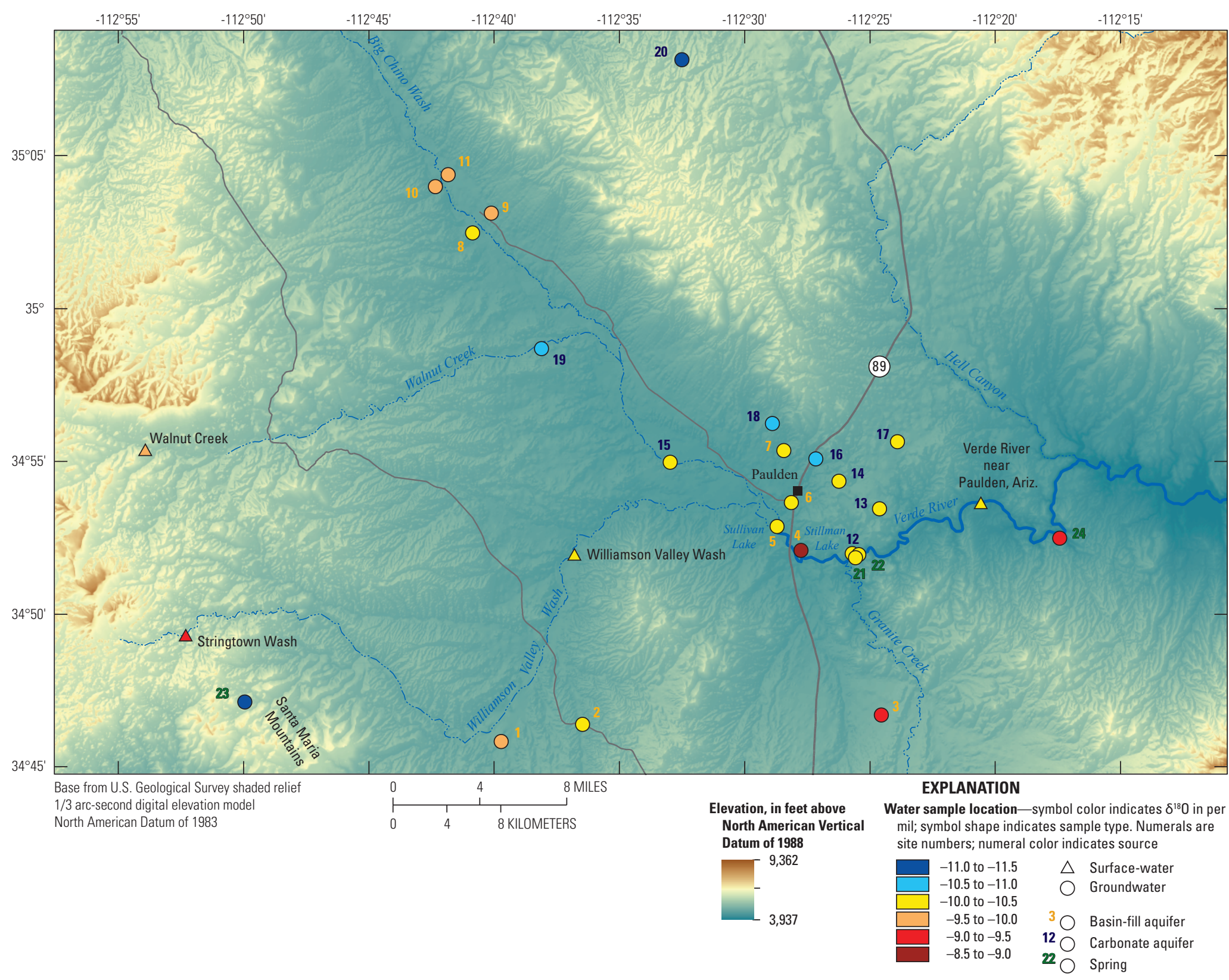

Figure 12. Stable isotope ratios of oxygen and hydrogen $(18 \mathrm{O}$ and $2 \mathrm{H})$ in the study area. Site names are presented in table 1. 


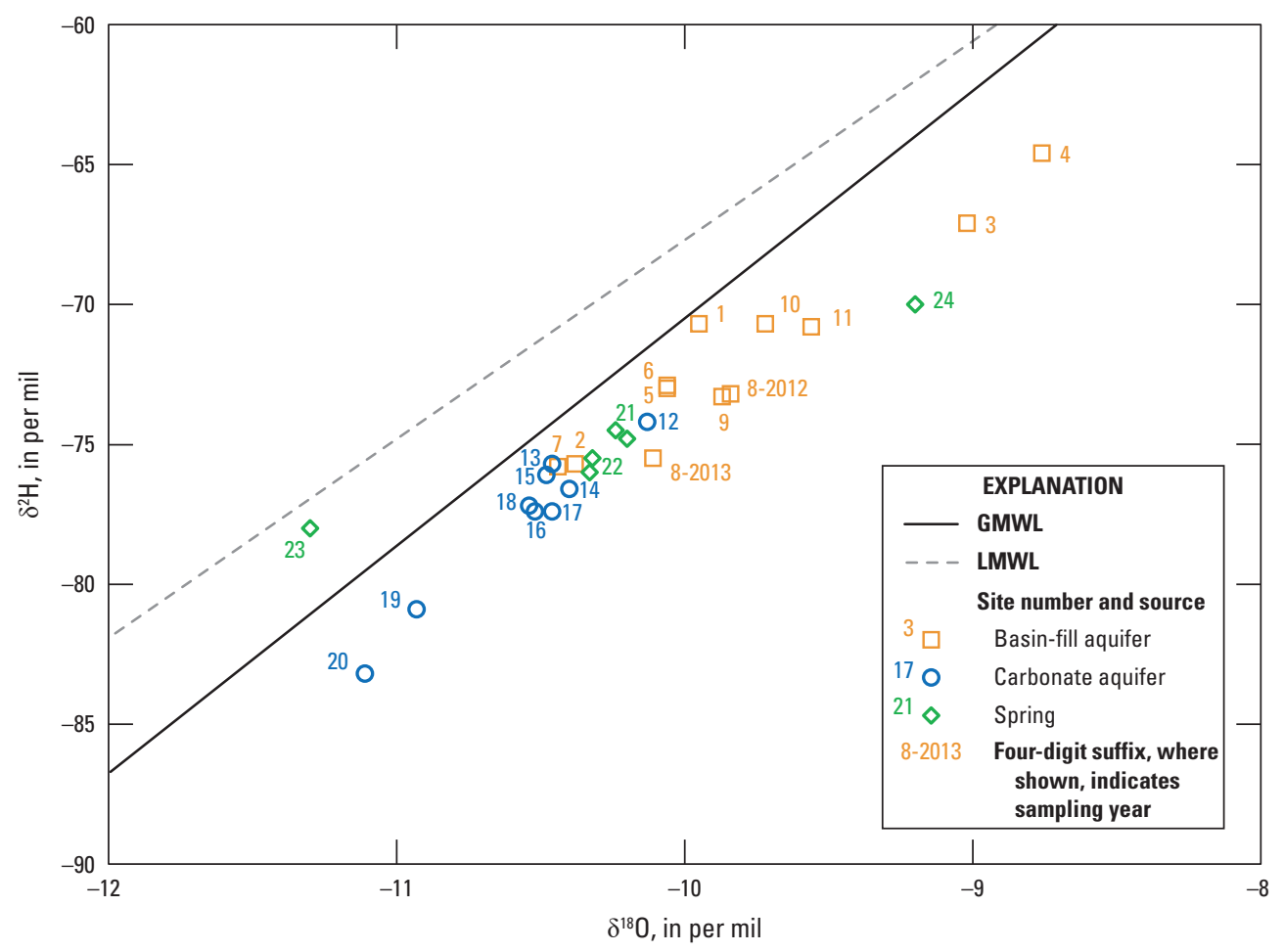

Figure 13. Relation between stable isotope ratios of oxygen and hydrogen $\left(\delta^{18} \mathrm{O}\right.$ and $\left.\delta^{2} \mathrm{H}\right)$ for groundwater samples, categorized by source. Global meteoric water line (GMWL) from Craig (1961) and local meteoric water line (LMWL) from Beisner and others (2016).

water that range from 25.1 to 37.1 years (table 7). Site 5 potentially has a fraction of young water that is 82.9 years old, which could indicate some water recharged prior to the bomb pulse that started in 1952.

Groundwater age is inferred from ${ }^{14} \mathrm{C}$ with corrections based on total dissolved inorganic carbon (the sum of inorganic carbon species carbonic acid, bicarbonate, and carbonate) and $\delta^{13} \mathrm{C}$. Graphing of carbon species helps in understanding the potential processes influencing carbon water chemistry at groundwater sampling sites before interpretation of groundwater age, similar to Han and others (2012) and Han and Plummer (2016) (fig. 16; table 8). The zero-age lines on figure 16 are determined from the soil gas and solid carbonate ${ }^{14} \mathrm{C}$ and $\delta^{13} \mathrm{C}$ values. Samples that plot between the zeroage lines on figure 16 do not have a calculated radiocarbon age and may be explained by geochemical reaction with no radiocarbon decay. Samples that plot above the zero-age area are likely mixtures containing some old and young recharged water, and samples that plot below the zero-age area may have a radiocarbon age greater than zero, indicating the presence of old water that has undergone radiocarbon decay (Han and Plummer, 2016). Water recharged prior to 11,700 years before present (B.P.) is considered to be primarily recharged during the Pleistocene, and water younger than 11,700 years B.P. is considered primarily recharged during the Holocene. Results from NetpathXL are presented in table 8 for the revised Fontes and Garnier model (solid exchange) radiocarbon ages (Han and Plummer, 2013).
Samples from several sites plot below the zero-age areas, indicating they may be old waters that could have undergone ${ }^{14} \mathrm{C}$ decay (fig. 16) (Han and others, 2012). Sites with a possible radiocarbon age include basin-fill aquifer wells (sites 5, $7,8,10)$, all carbonate aquifer wells (sites 12-20), and the UVS (sites 21 and 22) (fig. 16; table 8). Groundwater ages for wells 5 and 20 are within the range of Pleistocene recharge, and the range of possible groundwater age at wells 8 and 19 overlaps with the Pleistocene. Groundwater from other wells and springs that has a radiocarbon age indicates recharge occurred primarily during the Holocene.

The oldest groundwater sampled in this study had a high $\mathrm{CO}_{2}$ concentration and was from site 20, which is a deep well completed in carbonate rock. The corrected age range for this groundwater was 30,598 to 34,648 years B.P. (table 8). The stable isotopic values for this groundwater are the most depleted in the study area $\left(-83.2\right.$ and -11.11 for $\delta^{2} \mathrm{H}$ and $\delta^{18} \mathrm{O}$, respectively) and may represent water recharged during a previous climate in the Pleistocene. Relative to present conditions, estimated mean annual temperatures were 3 to $5{ }^{\circ} \mathrm{C}$ cooler and annual precipitation was greater (including greater winter precipitation and potential lack of monsoonal precipitation) between 59,000 and 14,000 years B.P. (Anderson and others, 2000), which could have affected the stable isotopic ratio of precipitation. Plant communities north of the Grand Canyon have been consistent since 14,040 years B.P., before which there is evidence of trees being present at lower 
Table 5. Noble gas data for groundwater samples collected in the study area.

[Dates shown as month, day, year. Noble gas concentrations are presented in cubic centimeters at standard temperature and pressure per gram of water (ccSTP/g). R/Ra, ratio of $3 \mathrm{He}$ to $4 \mathrm{He}$ in the sample relative to the value in the atmosphere; --, not measured]

\begin{tabular}{|c|c|c|c|c|c|c|c|c|c|}
\hline Site number & Site name & Sample date & Helium & Neon & Argon & Krypton & Xenon & Nitrogen & $\mathbf{R} / \mathbf{R a}$ \\
\hline \multicolumn{10}{|c|}{ Basin-fill aquifer } \\
\hline 1 & B-16-04 14CCB1 & $8 / 24 / 2017$ & $8.62 \mathrm{E}-08$ & $3.11 \mathrm{E}-07$ & $4.86 \mathrm{E}-04$ & $1.03 \mathrm{E}-07$ & $1.36 \mathrm{E}-08$ & $2.09 \mathrm{E}-02$ & 1.003 \\
\hline 2 & B-16-03 17BBD1 & $7 / 2 / 2014$ & 7.32E-08 & $3.02 \mathrm{E}-07$ & 4.10E-04 & $9.01 \mathrm{E}-08$ & $1.20 \mathrm{E}-08$ & $1.70 \mathrm{E}-02$ & 1.322 \\
\hline 3 & B-16-01 07CBD1 & $8 / 23 / 2017$ & 4.01E-08 & $1.74 \mathrm{E}-07$ & 3.09E-04 & $6.98 \mathrm{E}-08$ & $9.85 \mathrm{E}-09$ & $1.27 \mathrm{E}-02$ & 0.972 \\
\hline 4 & B-17-02 10CAC1 & $8 / 22 / 2017$ & 4.09E-08 & $1.79 \mathrm{E}-07$ & $3.14 \mathrm{E}-04$ & $6.56 \mathrm{E}-08$ & 9.04E-09 & $1.24 \mathrm{E}-02$ & 1.604 \\
\hline 5 & B-17-02S04DBC3 & $8 / 5 / 2015$ & $2.75 \mathrm{E}-07$ & $1.75 \mathrm{E}-07$ & $3.12 \mathrm{E}-04$ & 7.23E-08 & $1.03 \mathrm{E}-08$ & $1.22 \mathrm{E}-02$ & 0.221 \\
\hline 6 & B-17-02 03BBB1 & $7 / 1 / 2014$ & $9.81 \mathrm{E}-07$ & $1.72 \mathrm{E}-07$ & 3.03E-04 & $6.90 \mathrm{E}-08$ & $9.29 \mathrm{E}-09$ & $1.07 \mathrm{E}-02$ & 0.154 \\
\hline 7 & B-18-02 28AAB1 & $8 / 22 / 2017$ & $5.05 \mathrm{E}-05$ & $1.85 \mathrm{E}-07$ & $3.21 \mathrm{E}-04$ & $7.08 \mathrm{E}-08$ & $9.92 \mathrm{E}-09$ & -- & 0.111 \\
\hline 8 & B-19-04 10CCB2 & $6 / 27 / 2012$ & $2.44 \mathrm{E}-05$ & $1.36 \mathrm{E}-07$ & $2.97 \mathrm{E}-04$ & 5.10E-08 & 6.37E-09 & $1.82 \mathrm{E}-02$ & 0.126 \\
\hline 8 & B-19-04 10СCB2 & $6 / 5 / 2013$ & $1.16 \mathrm{E}-04$ & $1.36 \mathrm{E}-07$ & $3.68 \mathrm{E}-04$ & $6.56 \mathrm{E}-08$ & 8.94E-09 & $2.96 \mathrm{E}-02$ & 0.092 \\
\hline 9 & B-19-04 10AAC & $7 / 2 / 2014$ & $6.49 \mathrm{E}-08$ & $2.14 \mathrm{E}-07$ & $3.40 \mathrm{E}-04$ & 7.47E-08 & $1.02 \mathrm{E}-08$ & $1.25 \mathrm{E}-02$ & 0.912 \\
\hline 10 & B-19-04 05ABA1 & $8 / 6 / 2015$ & $1.90 \mathrm{E}-05$ & $1.98 \mathrm{E}-07$ & $3.10 \mathrm{E}-04$ & $6.64 \mathrm{E}-08$ & $9.13 \mathrm{E}-09$ & $1.17 \mathrm{E}-02$ & 0.124 \\
\hline 11 & B-20-04 33CBD2 & $6 / 13 / 2012$ & $4.71 \mathrm{E}-08$ & $2.02 \mathrm{E}-07$ & $2.41 \mathrm{E}-04$ & $5.08 \mathrm{E}-08$ & $6.21 \mathrm{E}-09$ & $1.33 \mathrm{E}-02$ & 1.088 \\
\hline \multicolumn{10}{|c|}{ Carbonate aquifer } \\
\hline 12 & B-17-02 12CBD1 & $2 / 20 / 2018$ & $1.16 \mathrm{E}-05$ & $1.84 \mathrm{E}-07$ & 3.09E-04 & $6.57 \mathrm{E}-08$ & $9.10 \mathrm{E}-09$ & $1.25 \mathrm{E}-02$ & 0.052 \\
\hline 13 & B-18-01 31CCC1 & $2 / 21 / 2018$ & $8.68 \mathrm{E}-06$ & 2.07E-07 & $3.16 \mathrm{E}-04$ & $6.46 \mathrm{E}-08$ & $8.56 \mathrm{E}-09$ & -- & 0.095 \\
\hline 13 & B-18-01 31CCC1 & $2 / 21 / 2018$ & $6.23 \mathrm{E}-06$ & $1.92 \mathrm{E}-07$ & $3.02 \mathrm{E}-04$ & $6.30 \mathrm{E}-08$ & 8.40E-09 & $1.26 \mathrm{E}-02$ & 0.091 \\
\hline 14 & B-18-02 35ABA1 & $6 / 8 / 2017$ & $1.75 \mathrm{E}-05$ & $1.56 \mathrm{E}-07$ & 2.84E-04 & $6.33 \mathrm{E}-08$ & 8.90E-09 & -- & 0.112 \\
\hline 15 & B-18-03 26BDD2 & $4 / 29 / 2018$ & $3.19 \mathrm{E}-05$ & 2.04E-07 & $3.49 \mathrm{E}-04$ & 7.41E-08 & $1.02 \mathrm{E}-08$ & $1.40 \mathrm{E}-02$ & 0.098 \\
\hline 16 & B-18-02 26BBC1 & $8 / 23 / 2017$ & $2.04 \mathrm{E}-05$ & $1.59 \mathrm{E}-07$ & $2.78 \mathrm{E}-04$ & $6.15 \mathrm{E}-08$ & 8.78E-09 & -- & 0.102 \\
\hline 17 & B-18-01 19ADC1 & $4 / 29 / 2018$ & $5.00 \mathrm{E}-06$ & $1.77 \mathrm{E}-07$ & $2.89 \mathrm{E}-04$ & $6.13 \mathrm{E}-08$ & 8.34E-09 & -- & 0.084 \\
\hline 18 & B-18-02 21BAB1 & $7 / 1 / 2014$ & $6.79 \mathrm{E}-05$ & $2.00 \mathrm{E}-07$ & 3.37E-04 & $7.66 \mathrm{E}-08$ & $9.54 \mathrm{E}-09$ & 8.03E-03 & 0.106 \\
\hline 19 & B-18-04 01ABD1 & $6 / 13 / 2018$ & $2.83 \mathrm{E}-04$ & $1.63 \mathrm{E}-07$ & 3.77E-04 & $6.63 \mathrm{E}-08$ & $9.00 \mathrm{E}-09$ & -- & 0.069 \\
\hline 20 & B-20-03 11AAC1 & $6 / 25 / 2018$ & 4.48E-04 & $1.63 \mathrm{E}-07$ & $3.66 \mathrm{E}-04$ & 5.82E-08 & 7.87E-09 & -- & 0.058 \\
\hline \multicolumn{10}{|c|}{ Springs } \\
\hline 21 & B-17-02 12CCA2 & $6 / 6 / 2017$ & $7.68 \mathrm{E}-06$ & $1.62 \mathrm{E}-07$ & $2.90 \mathrm{E}-04$ & $6.60 \mathrm{E}-08$ & $9.02 \mathrm{E}-09$ & $1.05 \mathrm{E}-02$ & 0.123 \\
\hline 21 & B-17-02 12CCA2 & $6 / 11 / 2018$ & $8.06 \mathrm{E}-06$ & $1.76 \mathrm{E}-07$ & $3.10 \mathrm{E}-04$ & $6.65 \mathrm{E}-08$ & $9.12 \mathrm{E}-09$ & $1.25 \mathrm{E}-02$ & 0.093 \\
\hline 22 & B-17-02 12CAC1 & $6 / 6 / 2017$ & $5.35 \mathrm{E}-06$ & $1.44 \mathrm{E}-07$ & 2.64E-04 & $6.02 \mathrm{E}-08$ & 8.00E-09 & -- & 0.121 \\
\hline 22 & B-17-02 12CAC1 & $6 / 11 / 2018$ & $1.40 \mathrm{E}-05$ & $1.61 \mathrm{E}-07$ & $2.86 \mathrm{E}-04$ & $6.25 \mathrm{E}-08$ & 8.70E-09 & -- & 0.068 \\
\hline 23 & B-16-05 06SBBC & $6 / 27 / 2011$ & 9.67E-08 & $1.90 \mathrm{E}-07$ & $3.22 \mathrm{E}-04$ & 7.69E-08 & $1.10 \mathrm{E}-08$ & $1.31 \mathrm{E}-02$ & 0.524 \\
\hline 24 & A-17-01 07AAA UNSURV & $6 / 27 / 2011$ & $6.26 \mathrm{E}-08$ & $1.69 \mathrm{E}-07$ & 2.79E-04 & $6.34 \mathrm{E}-08$ & 8.64E-09 & $1.02 \mathrm{E}-02$ & 0.718 \\
\hline
\end{tabular}


Table 6. Noble gas recharge elevation and temperature for groundwater samples collected in the study area.

[Dates shown as month, day, year. Elevation is reported in feet above the North American Vertical Datum of 1988. ft, foot; ${ }^{\circ} \mathrm{C}$, degrees Celsius; Ae, concentration of air trapped as water table rises; ccSTP/g, cubic centimeters at standard temperature and pressure per gram of water; F, fractionation factor-degree to which the atmospheric gases become fractionated during dissolution; EA, excess air; Chi², chi-squared statistic]

\begin{tabular}{|c|c|c|c|c|c|c|c|c|c|}
\hline $\begin{array}{c}\text { Site } \\
\text { number }\end{array}$ & $\begin{array}{c}\text { Site } \\
\text { name }\end{array}$ & $\begin{array}{c}\text { Sample } \\
\text { date }\end{array}$ & $\begin{array}{c}\text { Site } \\
\text { elevation } \\
\text { (ft) }\end{array}$ & $\begin{array}{c}\text { Recharge } \\
\text { elevation } \\
\text { (ft) }\end{array}$ & $\begin{array}{c}\text { Recharge } \\
\text { temperature } \\
\left({ }^{\circ} \mathrm{C}\right)\end{array}$ & $\begin{array}{c}\mathrm{Ae} \\
\text { (ccSTP/g) }\end{array}$ & $\begin{array}{c}\mathbf{F} \\
\text { (unitless) }\end{array}$ & $\begin{array}{c}\text { EA } \\
\text { (ccSTP/g) }\end{array}$ & Chi2 \\
\hline 1 & B-16-04 14CCB1 & $8 / 24 / 2017$ & 4,630 & 8,940 & 4.5 & 0.0489 & 0.40 & 0.0138 & 0.08 \\
\hline 2 & B-16-03 17BBD1 & $7 / 2 / 2014$ & 4,680 & 8,694 & 5.2 & 0.0155 & 0.24 & 0.0097 & 0.69 \\
\hline 3 & B-16-01 07CBD1 & $8 / 23 / 2017$ & 4,665 & 5,512 & 13.1 & 0.0253 & 0.88 & 0.0013 & 0.06 \\
\hline 5 & B-17-02S04DBC3 & $8 / 5 / 2015$ & 4,362 & 6,644 & 10.3 & 0.0075 & 0.77 & 0.0013 & 0.02 \\
\hline 6 & B-17-02 03BBB1 & $7 / 1 / 2014$ & 4,395 & 4,364 & 16.1 & 0.1548 & 0.94 & 0.0010 & 0.22 \\
\hline 7 & B-18-02 28AAB1 & $8 / 22 / 2017$ & 4,505 & 4,921 & 14.7 & 0.0534 & 0.84 & 0.0022 & 0.23 \\
\hline 9 & B-19-04 10AAC & $7 / 2 / 2014$ & 4,563 & 5,512 & 13.1 & 0.0189 & 0.63 & 0.0041 & 0.01 \\
\hline 110 & B-19-04 05ABA1 & $8 / 6 / 2015$ & 4,574 & 4,495 & 17.2 & 0.0134 & 0.68 & 0.0028 & 0.22 \\
\hline 112 & B-17-02 12CBD1 & $2 / 20 / 2018$ & 4,463 & 3,937 & 18.6 & 0.0463 & 0.85 & 0.0020 & 1.52 \\
\hline 114 & B-18-02 35ABA1 & $6 / 8 / 2017$ & 4,580 & 4,495 & 16.8 & 0.5000 & 1.00 & 0.0000 & 2.08 \\
\hline 15 & B-18-03 26BDD2 & $4 / 29 / 2018$ & 4,405 & 4,364 & 16.0 & 0.0837 & 0.77 & 0.0040 & 0.98 \\
\hline${ }^{1} 16$ & B-18-02 26BBC1 & $8 / 23 / 2017$ & 4,565 & 3,937 & 18.5 & 0.0000 & 1.00 & 0.0000 & 1.56 \\
\hline 118 & B-18-02 21BAB1 & $7 / 1 / 2014$ & 4,595 & 4,167 & 18.1 & 0.1877 & 0.79 & 0.0039 & 1.74 \\
\hline 21 & B-17-02 12CCA2 & $6 / 6 / 2017$ & 4,240 & 4,199 & 16.1 & 0.5000 & 1.00 & 0.0000 & 0.54 \\
\hline 121 & B-17-02 12CCA2 & $6 / 11 / 2018$ & 4,240 & 4,560 & 17.0 & 0.0997 & 0.89 & 0.0017 & 1.85 \\
\hline 122 & B-17-02 12CAC1 & $6 / 11 / 2018$ & 4,240 & 4,495 & 17.2 & 0.0939 & 0.98 & 0.0002 & 1.28 \\
\hline 23 & B-16-05 06SBBC & $6 / 27 / 2011$ & 5,570 & 8,005 & 6.9 & 0.0020 & 0.00 & 0.0020 & 0.40 \\
\hline 124 & A-17-01 07AAA UNSURV & $6 / 27 / 2011$ & 4,055 & 3,937 & 18.4 & 0.0004 & 0.00 & 0.0004 & 0.21 \\
\hline
\end{tabular}

${ }_{1}^{1}$ For this site, the lowest elevation recharge solution is above the temperature lapse rate +1.5 degrees Celsius $(\mathrm{Ta}+1.5)$ line and values are reported for crossing of the Ta +3 line. 

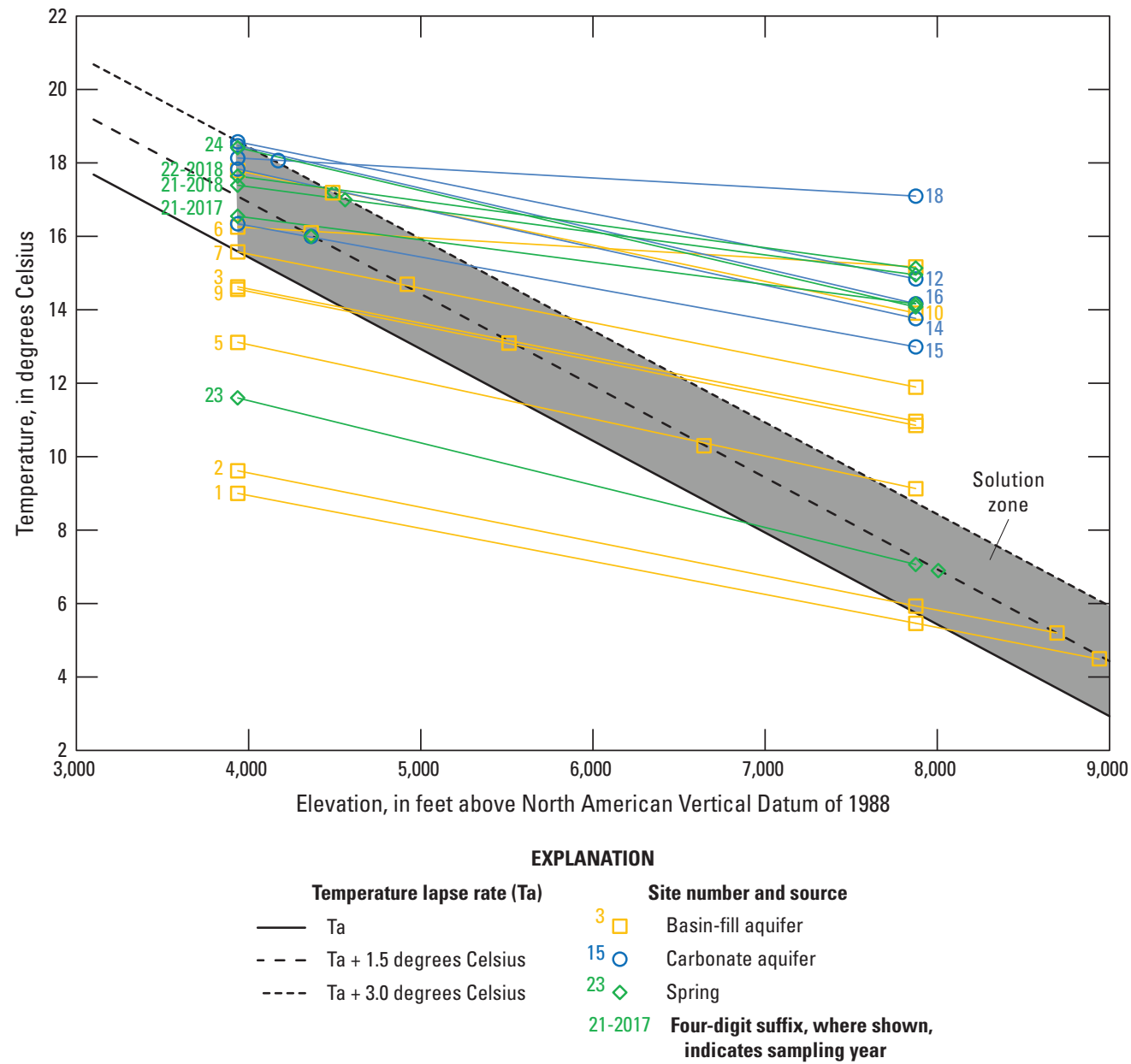

Figure 14. Noble gas recharge elevation and temperature for groundwater samples relative to the temperature lapse rate.

Table 7. Apparent age of fraction of young tritiated water sampled in the study area.

[Dates shown as month, day, year. Age determinations assume a terrigenic helium $(\mathrm{He})$ value of $2 \mathrm{E}-08$. pCi/L, picocuries per liter; $\mathrm{TU}$, tritium units; ${ }^{3} \mathrm{He}$ trit, tritiogenic helium]

\begin{tabular}{|c|c|c|c|c|c|c|c|}
\hline $\begin{array}{c}\text { Site } \\
\text { number }\end{array}$ & $\begin{array}{c}\text { Site } \\
\text { name }\end{array}$ & $\begin{array}{l}\text { Sample } \\
\text { date }\end{array}$ & $\begin{array}{l}\text { Tritium } \\
\text { (pCi/L) }\end{array}$ & $\begin{array}{l}\text { Tritium } \\
\text { (TU) }\end{array}$ & $\begin{array}{l}{ }^{3} \mathrm{He}_{\text {trit }} \\
\text { (TU) }\end{array}$ & $\begin{array}{l}\text { Apparent } \\
\text { age } \\
\text { (years) }\end{array}$ & $\begin{array}{c}\text { Initial } \\
\text { tritium } \\
\text { (TU) }\end{array}$ \\
\hline \multicolumn{8}{|c|}{ Basin-fill aquifer } \\
\hline 1 & B-16-04 14CCB1 & $8 / 24 / 2017$ & 5 & 1.55 & 8.25 & 32.8 & 9.80 \\
\hline 2 & B-16-03 17BBD1 & $7 / 2 / 2014$ & 11.4 & 3.55 & 13.05 & 27.4 & 16.60 \\
\hline 4 & B-17-02 10CAC1 & $8 / 22 / 2017$ & 5.79 & 1.80 & 12.75 & 37.1 & 14.55 \\
\hline 5 & B-17-02S04DBC3 & $8 / 5 / 2015$ & 0.29 & 0.09 & 9.46 & 82.9 & 9.55 \\
\hline 9 & B-19-04 10AAC & 7/2/2014 & 2.5 & 0.78 & 4.74 & 34.8 & 5.52 \\
\hline \multicolumn{8}{|c|}{ Springs } \\
\hline 23 & B-16-05 06SBBC & $6 / 27 / 2011$ & 2.6 & 0.80 & 2.99 & 27.7 & 3.79 \\
\hline 24 & $\begin{array}{l}\text { A-17-01 07AAA UN- } \\
\text { SURV }\end{array}$ & $6 / 27 / 2011$ & 2.6 & 0.80 & 2.48 & 25.1 & 3.28 \\
\hline
\end{tabular}




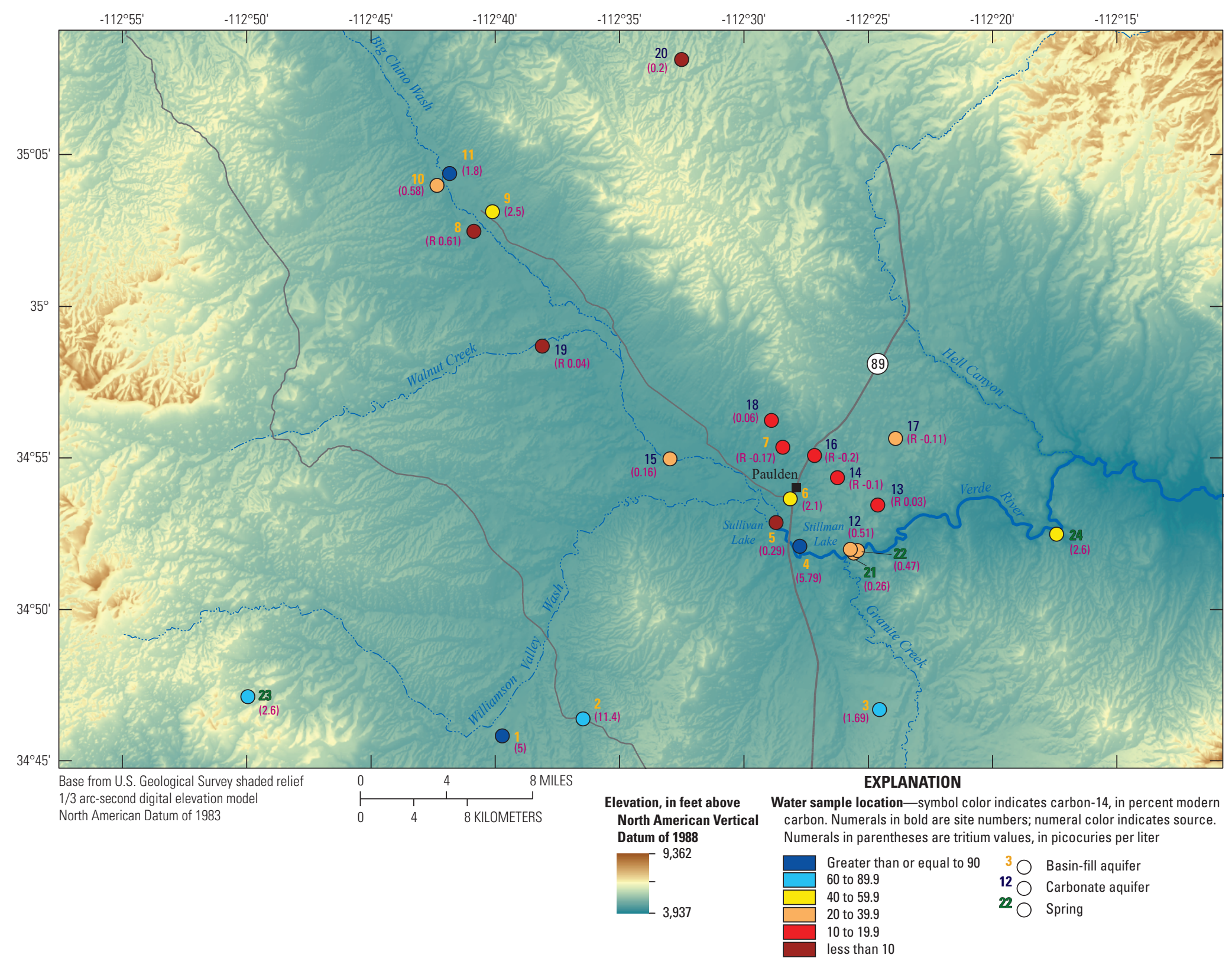

Figure 15. Radiocarbon (carbon-14) and tritium values in the study area. Site names are presented in table 1. $R$ indicates tritium value was less than the laboratory reporting level. 
Table 8. Radiocarbon and tritium groundwater age dating data.

[pCi/L, picocuries per liter; ${ }^{14} \mathrm{C}$, carbon-14; pmc, percent modern carbon; pM, normalized percent modern carbon; B.P., before present; R, radiochemistry nondetect; --, not applicable; ND, not determined. For minimum and maximum age, -18 and -12 indicate the per mil value of soil gas used in radiocarbon age calculation]

\begin{tabular}{|c|c|c|c|c|c|c|c|c|c|}
\hline $\begin{array}{c}\text { Site } \\
\text { number }\end{array}$ & Site name & $\begin{array}{l}\text { Sample } \\
\text { date }\end{array}$ & $\begin{array}{l}\text { Tritium } \\
\text { (pCi/L) }\end{array}$ & $\begin{array}{c}\text { Denormalized } \\
{ }_{14 C} \\
\text { (pmc) }\end{array}$ & $\begin{array}{c}\text { Normalized } \\
{ }_{14 C} \\
\text { (pM) }\end{array}$ & $\begin{array}{l}{ }^{14} \mathrm{C} \text { error } \\
(\mathrm{pM})\end{array}$ & $\begin{array}{c}{ }^{13 C} \\
\text { (per mil) }\end{array}$ & $\begin{array}{c}\text { Minimum corrected } \\
\text { age (-18) } \\
\text { (years B.P.) }\end{array}$ & $\begin{array}{c}\text { Maximum corrected } \\
\text { age }(-12) \\
\text { (years B.P.) }\end{array}$ \\
\hline \multicolumn{10}{|c|}{ Basin-fill aquifer } \\
\hline 1 & B-16-04 14CCB1 & $8 / 24 / 2017$ & 5 & 97.05 & 95.67 & 0.2 & -14.03 & -- & -- \\
\hline 2 & B-16-03 17BBD1 & $7 / 2 / 2014$ & 11.4 & 88.51 & 86.79 & 0.2 & -11.56 & -- & -- \\
\hline 3 & B-16-01 07CBD1 & $8 / 23 / 2017$ & 1.69 & 69.66 & 67.98 & 0.19 & -9 & -- & -- \\
\hline 4 & B-17-02 10CAC1 & $8 / 22 / 2017$ & 5.79 & 98.81 & 96.91 & 0.19 & -11.51 & -- & -- \\
\hline 5 & B-17-02S04DBC3 & $8 / 5 / 2015$ & 0.29 & 9.22 & 9.01 & 0.11 & -9.81 & 13,293 & 17,233 \\
\hline 6 & B-17-02 03BBB1 & $7 / 1 / 2014$ & 2.1 & 56.27 & 54.88 & 0.17 & -8.94 & -- & -- \\
\hline 7 & B-18-02 28AAB1 & $8 / 22 / 2017$ & $\mathrm{R}-0.17$ & 18.65 & 18.11 & 0.09 & -6.44 & 1,574 & 5,714 \\
\hline 8 & B-19-04 10CCB2 & $6 / 27 / 2012$ & R 0.61 & 4.24 & 4.1 & 0.11 & -5.01 & 10,607 & 14,609 \\
\hline 9 & B-19-04 10AAC & $7 / 2 / 2014$ & 2.5 & 54.08 & 52.65 & 0.14 & -8.04 & -- & -- \\
\hline 10 & B-19-04 05ABA1 & $8 / 6 / 2015$ & 0.58 & 21.10 & 20.53 & 0.13 & -7.71 & 3,547 & 7,476 \\
\hline 11 & B-20-04 33CBD2 & $6 / 13 / 2012$ & 1.8 & 96.20 & 93.87 & 0.24 & -9.25 & -- & -- \\
\hline \multicolumn{10}{|c|}{ Carbonate aquifer } \\
\hline 12 & B-17-02 12CBD1 & $2 / 20 / 2018$ & 0.51 & 33.99 & 33.07 & 0.11 & -7.45 & -- & 3,056 \\
\hline 13 & B-18-01 31CCC1 & $2 / 21 / 2018$ & R 0.03 & 19.26 & 18.69 & 0.08 & -6.2 & 1,148 & 5,153 \\
\hline 14 & B-18-02 35ABA1 & $6 / 8 / 2017$ & $\mathrm{R}-0.10$ & 18.91 & 18.35 & 0.09 & -6.18 & 1,216 & 5,294 \\
\hline 15 & B-18-03 26BDD2 & $4 / 29 / 2018$ & 0.16 & 38.17 & 37.17 & 0.13 & -7.85 & -- & 2,790 \\
\hline 16 & B-18-02 26BBC1 & $8 / 23 / 2017$ & $\mathrm{R}-0.20$ & 18.38 & 17.84 & 0.1 & -6.24 & 1,276 & 5,417 \\
\hline 17 & B-18-01 19ADC1 & $4 / 29 / 2018$ & $\mathrm{R}-0.11$ & 20.67 & 20.06 & 0.09 & -6.13 & 576 & 4,531 \\
\hline 18 & B-18-02 21BAB1 & $7 / 1 / 2014$ & 0.06 & 16.73 & 16.23 & 0.08 & -6.23 & 1,924 & 6,112 \\
\hline 19 & B-18-04 01ABD1 & $6 / 13 / 2018$ & R 0.04 & 4.75 & 4.6 & 0.06 & -5.17 & 8,474 & 12,785 \\
\hline 20 & B-20-03 11AAC1 & $6 / 25 / 2018$ & 0.2 & 0.55 & 0.53 & 0.05 & -6.6 & 30,598 & 34,648 \\
\hline \multicolumn{10}{|c|}{ Springs } \\
\hline 21 & B-17-02 12CCA2 & $6 / 6 / 2017$ & 0.26 & 33.18 & 32.28 & 0.11 & -7.45 & -- & 3,231 \\
\hline 21 & B-17-02 12CCA2 & $6 / 11 / 2018$ & R 0.15 & 33.50 & 32.6 & 0.14 & -7.53 & -- & 3,310 \\
\hline 22 & B-17-02 12CAC1 & $6 / 6 / 2017$ & 0.47 & 22.48 & 21.82 & 0.1 & -6.25 & -- & 3,997 \\
\hline 22 & B-17-02 12CAC1 & $6 / 11 / 2018$ & R 0.05 & 22.83 & 22.17 & 0.12 & -6.5 & 414 & 4,424 \\
\hline 23 & B-16-05 06SBBC & $6 / 27 / 2011$ & 2.6 & 81.10 & 80.1 & 0.3 & -15.3 & ND & ND \\
\hline 24 & $\begin{array}{l}\text { A-17-01 07AAA UN- } \\
\text { SURV }\end{array}$ & $6 / 27 / 2011$ & 2.6 & 40.26 & 39.2 & 0.2 & -8.2 & ND & ND \\
\hline
\end{tabular}




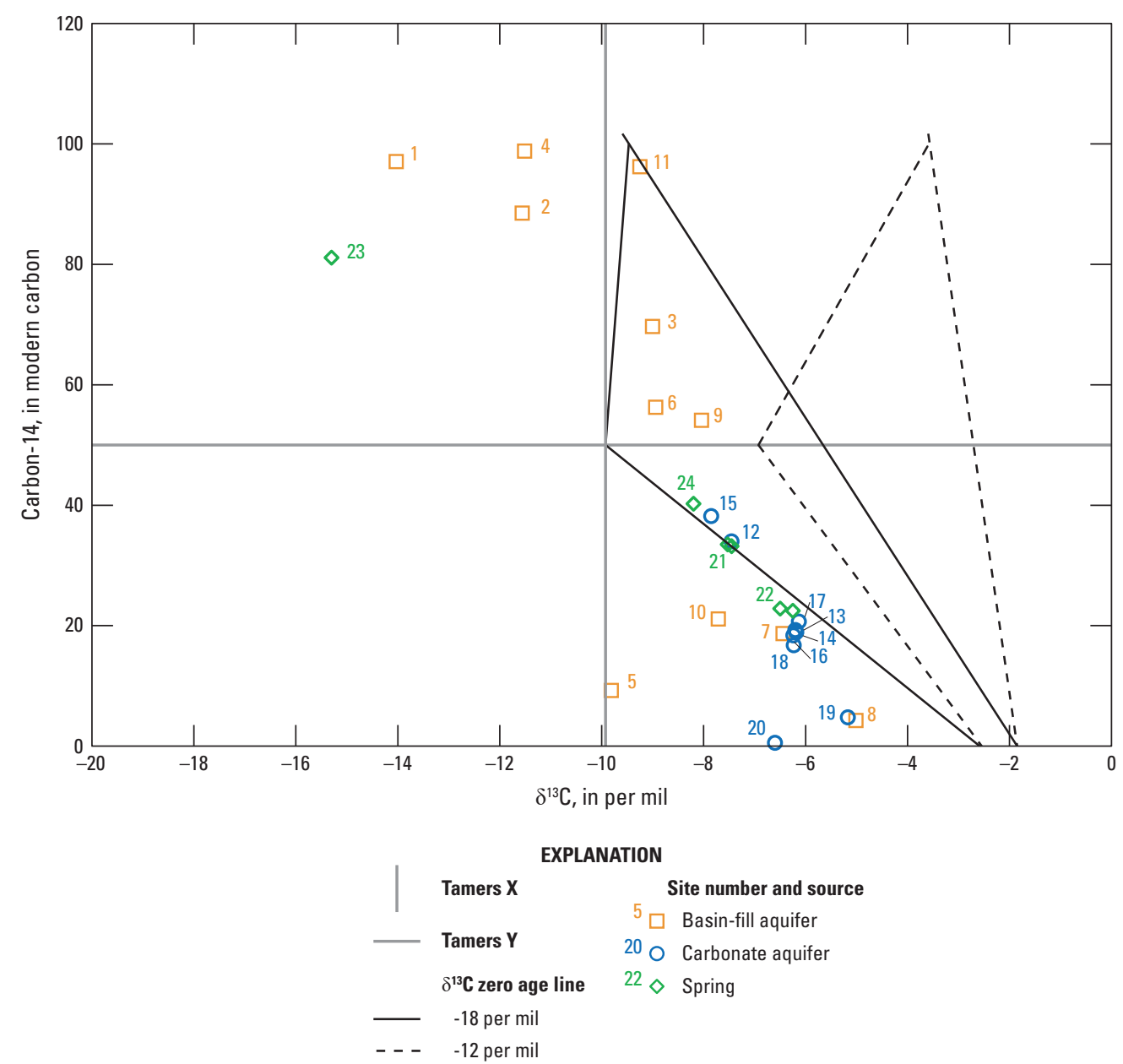

Figure 16. Relation between carbon-14 versus $\delta^{13} \mathrm{C}$ (ratio of carbon-13 to carbon-12, Vienna Pee Dee Belemnite [VPDB]).

elevations than today (Anderson and others, 2000), which could make the input $\delta^{13} \mathrm{C}$ of soil gas for recharge waters more negative compared to present day vegetation.

A group of three groundwater samples have corrected radiocarbon ages ranging from 17,233 to 8,474 years B.P., which includes a deep well completed in basalt basin-fill aquifer (site 8) near Big Chino Water Ranch, a deep well completed in the carbonate aquifer along Big Chino Wash near the Walnut Creek confluence (site 19), and a piezometer (site 5) in the basin-fill near where Big Chino Wash flows under State Highway 89 (figs. 4 and 16).

A deep well completed in the basin-fill aquifer near the Big Chino Water Ranch (site 10, fig. 4) had groundwater ranging from 7,476 to 3,547 years B.P. Another group of six groundwater samples with a radiocarbon age range from 6,112 to 576 years B.P. is located in northern Paulden and to the north of the UVS. The UVS (sites 21 and 22), a carbonate aquifer well (site 12) located just north of the gaining reach of the Upper Verde River, and a well completed in the carbonate aquifer (site 15) below the basin-fill of Big Chino Wash located to the west of Paulden, all plotted near or within the zero-age area when using -18 per mil for $\delta^{13} \mathrm{C}$ of soil gas and to the left of the zero-age area when using -12 per mil for $\delta^{13} \mathrm{C}$ of soil gas, resulting in corrected radiocarbon ages of 4,424 to 2,790 years B.P.

\section{Multivariate Analysis}

Multiple iterations of constituents were computed for multivariate statistics to determine the variation between groundwater at different sites when including different analytes. Duff Spring (site 24) and Cabin Spring (site 23) did not have a complete geochemical analysis suite and were excluded from the multivariate analysis. The following properties and constituents were included in the NMDS analysis: water temperature, $\mathrm{pH}$, specific conductance, calcium, sodium, bicarbonate, fluoride, arsenic, tritium, and $\delta^{18} \mathrm{O}$. The NMDS had a stress of 0.059 , indicating a fair fit with no real prospect for misleading interpretation, and was close to the 0.05 threshold for good fit (Clarke and others, 2014, p. 5-6). Generally, the samples from the basin-fill aquifer were distinct from the samples from the carbonate aquifer on the primary NMDS 
axis, with $\mathrm{pH}$, tritium, and $\delta^{18} \mathrm{O}$ separating the basin-fill samples (fig. 17). Carbonate groundwater samples generally were distinct from the basin-fill samples because of water temperature, specific conductance, calcium, sodium, bicarbonate, fluoride, and arsenic. Two basin-fill groundwater samples (sites 7 and 8) plotted in the same region as the carbonate samples. These two basin-fill samples may have groundwater that has interacted with carbonate upgradient of the well along its flow path from the recharge source. Samples from the UVS (UVS South [site 21] and Greenbie Pool [site 22]) plot near the center of the NMDS graph.

A cluster analysis was computed for samples and constituents from the NMDS. The Calinski criterion indicates that two is the significant number of groups for the dataset. The cluster analysis separates all carbonate aquifer, spring, and two basin-fill aquifer samples into one group and the rest of the basin-fill aquifer samples into another group. Samples from sites 8 and 20 are most dissimilar from the other samples in the first group - site 8 for elevated fluoride and site 20 for elevated calcium. Samples from UVS (UVS South [site 21] and Greenbie Pool [site 22]) are most similar to samples from sites 12, 13, 14, 15, and 17 (fig. 18).

\section{Comparison with Previous Studies}

Previous USGS studies by Wirt and others (2005c) and Blasch and others (2006) collected water-quality samples from the study area presented in this report using similar collection procedures and analytical methods. To our knowledge, only one well (site 4) sampled in this study was included in Blasch and others (2006); and some springs Cabin and Duff (sites 23 and 24) from Wirt and others (2005c) were resampled in this study. Additionally, some wells sampled as part of this study were screened in the same aquifer and located nearby previously sampled wells from Wirt and others (2005c). A comparison of the water chemistry results in this study and previous studies at identical or similar sites is presented in table 9 . The

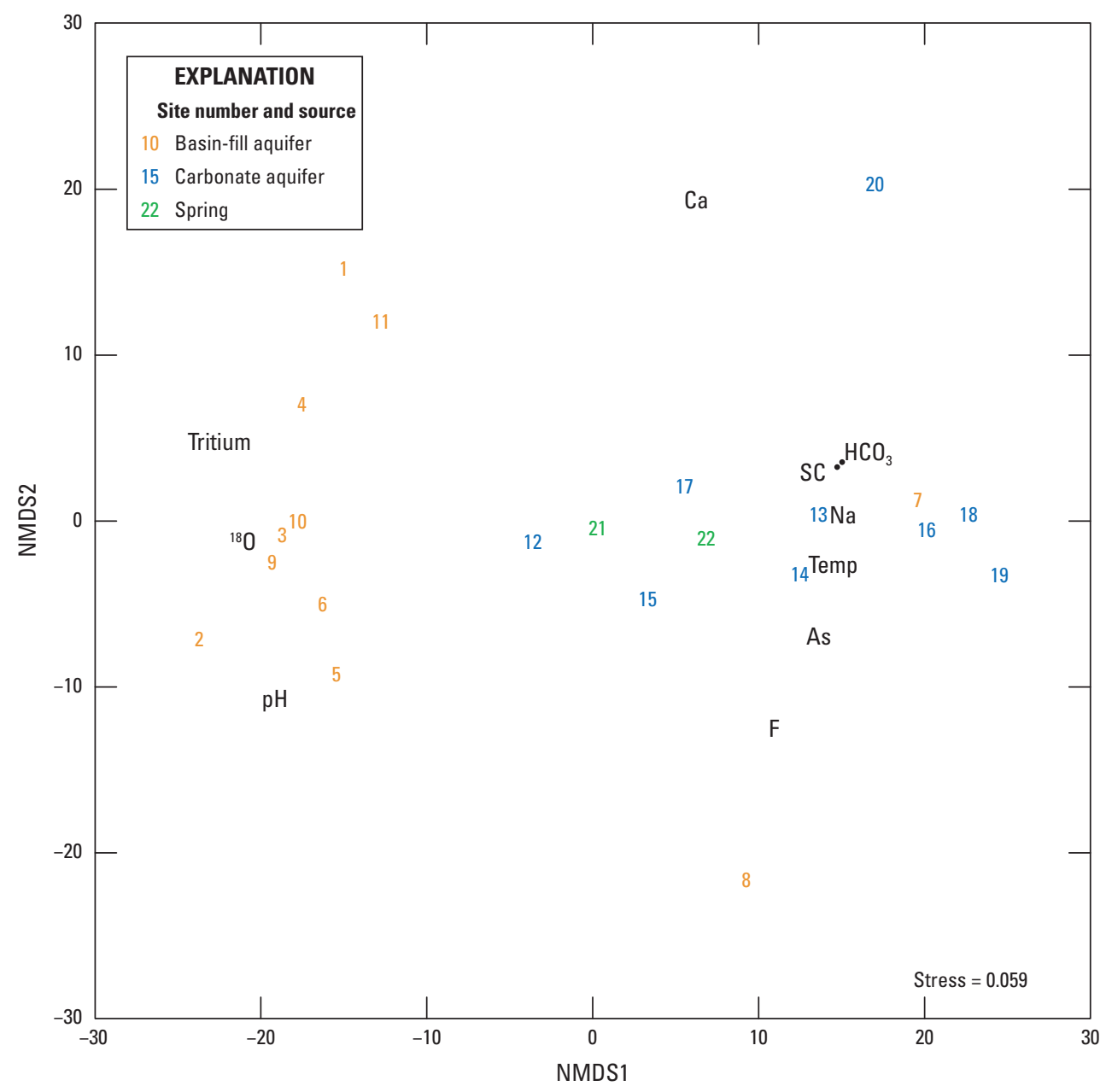

Figure 17. Nonmetric multidimensional scaling (NMDS) graph for groundwater samples. Sampling location map shown in figure 4. ${ }^{180}$, 180 ratio of oxygen-18 to oxygen-16; As, arsenic; $\mathrm{Ca}$, calcium; $\mathrm{F}$, fluoride; $\mathrm{HCO}_{3}$, bicarbonate; $\mathrm{Na}$, sodium; $\mathrm{pH}$, percent hydrogen; $\mathrm{SC}$, specific conductance; temp, water temperature. 


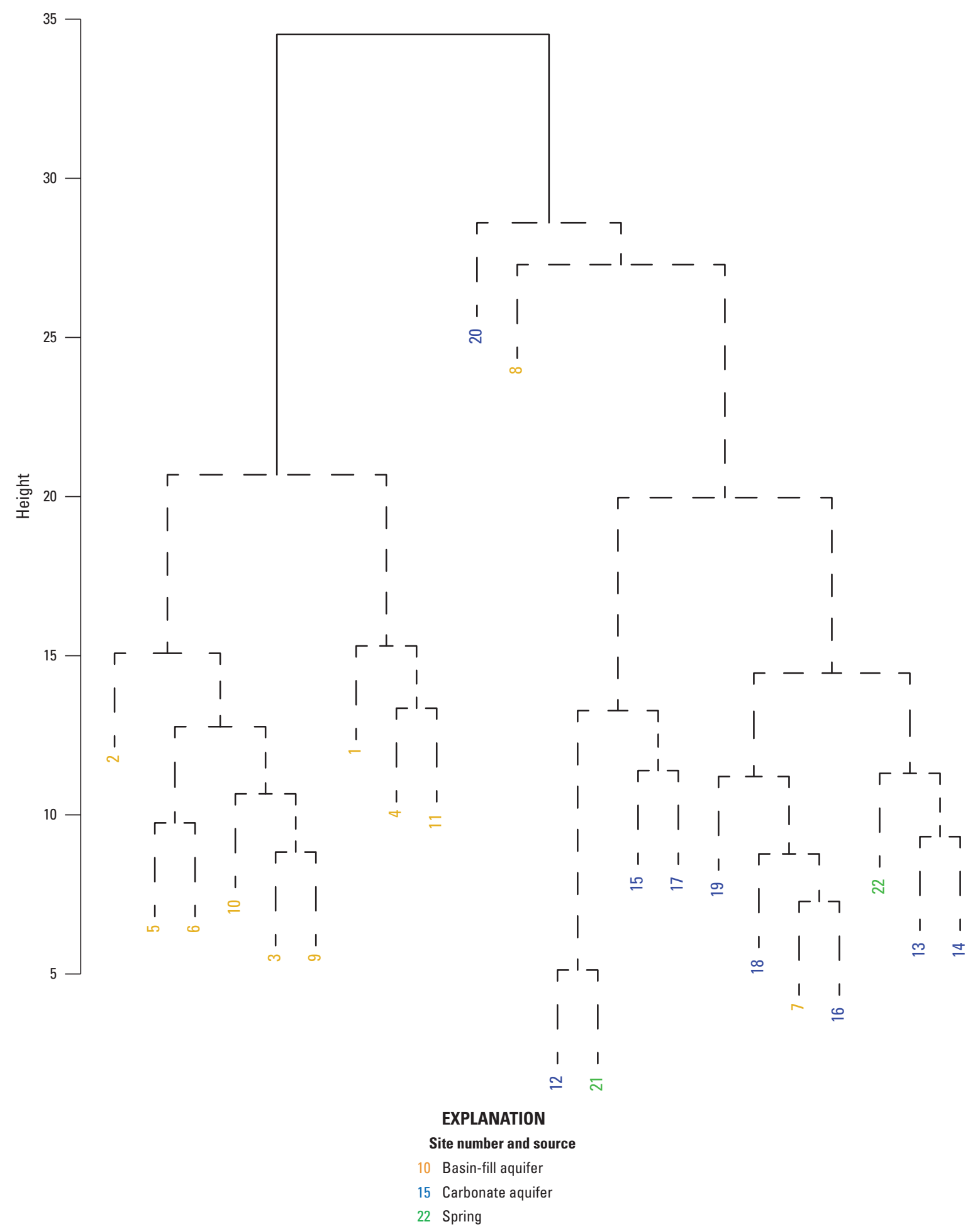

Figure 18. Cluster analysis for groundwater samples in the study area. Solid lines represent distinct groups as determined by the Calinski criterion and dashed lines show subdivisions considered indistinct. 
similarity of results in this study and the previous studies indicates water-quality changes are not substantial in the system near the locations presented in table 9 .

The aquifer characterization presented in Wirt and others $(2005 \mathrm{c})$ was re-evaluated to understand the categorization of aquifers. The driller's $\log$ for well F (B-17-02 02CAC), which was not resampled for this study, indicates that the well is presumably completed in volcanic rock, although Wirt and others (2005c) groups it with the carbonate aquifer underlying the Big Chino basin-fill aquifer (Devonian-Cambrian zone).

The water chemistry of well $\mathrm{F}$ is more similar to that of wells completed in basin-fill from this study (lower specific conductance, lower arsenic concentration, and less negative stable isotopes). Additionally, one well from Wirt and others (2005c) in the carbonate aquifer (B-18-02 27CDA with a common name of LS-12) underlying the Big Chino basin-fill aquifer (Devonian-Cambrian zone) group is $3,010 \mathrm{ft}$ deep, whereas the other wells assigned to the Devonian-Cambrian zone range from 285 to $480 \mathrm{ft}$ deep without large changes in land surface elevation between the sites. Of the wells in Wirt and others (2005c) in the 285 to $480 \mathrm{ft}$ range, well $\mathrm{H}$ (B-18-02 21 ACB) and well C-11 (B-18-02 27CBA) have limestone documented in the driller's log at the bottom of the well, but the other wells characterized as carbonate aquifer do not have associated driller's logs and are located near wells that are completed in basin-fill at similar depths.

\section{Groundwater Evolution}

The youngest water in the study area is located in basin-fill aquifers in the southern part of the study area along Williamson Valley Wash and near Granite Creek. The oldest water in the study area is generally located in deep carbonate aquifer wells. Site 20 groundwater has the oldest radiocarbon age, greater than 30,000 years B.P. (table 8), and (1) a distinctly more radiogenic strontium isotopic ratio value than that of groundwater at other sites, (2) a sodium-bicarbonate groundwater type, and (3) a depleted stable isotopic value similar to that of water from Cabin Spring (site 23), which is located at a similarly high elevation $(5,290 \mathrm{ft}$ for well versus $5,570 \mathrm{ft}$ for spring) in the Santa Maria Mountains. The water chemistry of this old groundwater is unique in the study area and does not seem to have a strong influence on the water chemistry at other wells in the study area. Additionally, there is a groundwater divide between water flowing north to the Grand Canyon and south to the Verde River that is not well defined near this site. Old groundwater is also present in carbonate wells (and one basin-fill well) in northern Paulden and north of the UVS.

Site 15 was the first well known to be completed in the Paleozoic carbonate aquifer below the basin-fill of Big Chino Valley downgradient from Walnut Creek and upgradient from Paulden. Site 19 represents groundwater in the Paleozoic carbonate aquifer below the basin-fill of Walnut Creek drainage and has an older groundwater age (about 13,000 to 8,000 years
B.P.) compared with site 15 (about 2,800 years B.P.), which indicates an input of water with a younger age near or downgradient from Walnut Creek. The stable isotopic signature between the two wells changes from -10.93 and -80.9 per mil to -10.48 and -76.1 per mil for $\delta^{18} \mathrm{O}$ and $\delta^{2} \mathrm{H}$, respectively, indicating the additional source of water may be from a lower elevation. The water at the downgradient well (site 15) has a lower strontium concentration, isotopic ratio, total dissolved solids concentration (primarily driven by a decrease in major ions except calcium and magnesium, which stayed at a similar concentration), and arsenic concentration. Tritium for both sites was below the detection limit, which indicates the contributing water was primarily recharged before 1952 .

The basin-fill thickness is deepest to the northwest in Big Chino Valley parallel to the Big Chino Fault (Langenheim and others, 2005c). The basin-fill thickness decreases downgradient of site 19 (Langenheim and others, 2005c), which may explain the discontinuity of water chemistry between the two wells (sites 15 and 19). Additionally, there is a major magnetic lineament that corresponds with a surface fault scarp near the confluence of Walnut Creek and Big Chino Wash (Langenheim and others, 2005c; Pearthree and Ferguson, 2012). The groundwater at site 19 may be pooling at a subsurface offset and represents an isolated reservoir of water compared with water in the carbonate downgradient in Big Chino Valley at site 15. An additional well completed in the same Paleozoic carbonate aquifer upgradient and downgradient from Walnut Creek would provide the means needed to make a valuable comparison of groundwater evolution along a flow path to better understand groundwater travel time and potential for mixing of groundwater from other sources.

Site 5 is located just upgradient from where the basinfill pinches out just upstream from the Verde River flowing through a constricted basalt canyon to the east of highway 89 (fig. 19). The groundwater at site 5 is old, based on radiocarbon dating, and may represent water in the basin-fill that has traveled through the subsurface along Big Chino Valley for a long time, assuming that the recharge water originated only farther upgradient in the basin. If additional sources of recharge to the basin-fill aquifer exist in Big Chino Valley along the flow path to site 5 , then the water at this site would likely reflect a younger age.

Sampling for an extensive suite of geochemical analytes between the basin-fill sites near Big Chino Water Ranch (sites $8,9,10$, and 11) and sites near Paulden would help clarify the evolution of water in the basin-fill. Although not sampled for this study, there are four wells completed in basin-fill along Big Chino Wash that were sampled for carbon-14, tritium, and stable isotopic values by Wirt and others $(2005 \mathrm{c})$. These samples can provide some context for groundwater evolution through the basin-fill aquifer. The wells are named B, C, D, and E in Wirt and DeWitt (2005), and their letter order increases downgradient along the basin, with well B closest to Big Chino Water Ranch and well E closest to Paulden. Wells B through $\mathrm{D}$ have similar carbon-14 values, ranging from 21 to 29.8 pmc, and well $\mathrm{E}$ has a substantially higher carbon-14 
Table 9. Groundwater chemistry comparison between this study and previous studies (Wirt and others, 2005c; Blasch and others, 2006).

[Shading indicates the same site was sampled in this study and a previous study by the U.S. Geological Survey. $\mu \mathrm{S} / \mathrm{cm}$ at $25^{\circ} \mathrm{C}$, microsiemens per centimeter at 25 degrees Celsius; As, arsenic; $\mu \mathrm{g} / \mathrm{L}$, micrograms per liter; pmc, percent modern carbon; NA, not available]

\begin{tabular}{|c|c|c|c|c|c|c|c|c|c|c|c|c|c|}
\hline \multirow{2}{*}{$\begin{array}{l}\text { Site } \\
\text { number } \\
\text { (this } \\
\text { study) }\end{array}$} & \multirow{2}{*}{$\begin{array}{c}\text { Site name } \\
\text { (Wirt and others, } \\
\text { 2005c, unless } \\
\text { otherwise } \\
\text { indicated) }\end{array}$} & \multicolumn{2}{|c|}{$\begin{array}{c}\text { Specific } \\
\text { conductance } \\
\text { ( } \mu \mathrm{s} / \mathrm{cm} \\
\left.\text { at } 25^{\circ} \mathrm{C}\right)\end{array}$} & \multicolumn{2}{|c|}{$\begin{array}{c}\text { As } \\
\text { concentration } \\
(\mu \mathrm{g} / \mathrm{L})\end{array}$} & \multicolumn{2}{|c|}{$\begin{array}{l}\text { Carbon-14 } \\
\text { (pmc) }\end{array}$} & \multicolumn{2}{|c|}{$\begin{array}{c}\delta^{13} \mathrm{C} \\
\text { (per mil) }\end{array}$} & \multicolumn{2}{|c|}{$\begin{array}{c}\delta^{180} \\
\text { (per mil) }\end{array}$} & \multicolumn{2}{|c|}{$\begin{array}{c}\delta^{2} \mathrm{H} \\
\text { (per mil) }\end{array}$} \\
\hline & & $\begin{array}{l}\text { This } \\
\text { study }\end{array}$ & $\begin{array}{l}\text { Previous } \\
\text { study }\end{array}$ & $\begin{array}{l}\text { This } \\
\text { study }\end{array}$ & $\begin{array}{l}\text { Previous } \\
\text { study }\end{array}$ & $\begin{array}{l}\text { This } \\
\text { study }\end{array}$ & $\begin{array}{l}\text { Previous } \\
\text { study }\end{array}$ & $\begin{array}{l}\text { This } \\
\text { study }\end{array}$ & $\begin{array}{l}\text { Previous } \\
\text { study }\end{array}$ & $\begin{array}{l}\text { This } \\
\text { study }\end{array}$ & $\begin{array}{l}\text { Previous } \\
\text { study }\end{array}$ & $\begin{array}{l}\text { This } \\
\text { study }\end{array}$ & $\begin{array}{l}\text { Previous } \\
\text { study }\end{array}$ \\
\hline 14 & ${ }^{2} \mathrm{~B}-17-02$ 10CAC & 570 & 548 & 5 & 5.1 & 96.91 & NA & -11.51 & NA & -8.76 & -8.81 & -64.6 & -66.3 \\
\hline 6 & $\begin{array}{l}\text { B-17-02 04DDC } \\
\text { (Well E) }\end{array}$ & 420 & 386 & 10.7 & NA & 54.88 & 54.7 & -8.94 & -8.2 & -10.06 & -10.3 & -72.9 & -73 \\
\hline 7 & B-18-02 28BAB & 868 & 699 & 48.6 & 37 & 18.11 & NA & -6.44 & NA & -10.44 & -10.1 & -75.8 & -74 \\
\hline 9 & $\begin{array}{l}\text { B-19-04 04BDB } \\
\text { (Well A) }\end{array}$ & 578 & 476 & 2.7 & 1 & 52.65 & 55 & -8.04 & -9.1 & -9.87 & -10 & -73.3 & -72 \\
\hline 18 & $\begin{array}{l}\text { B-18-02 21ACB } \\
\text { (Well H) }\end{array}$ & 929 & 903 & 60.3 & NA & 16.23 & 18 & -6.23 & -5.6 & -10.54 & -10.7 & -77.2 & -77 \\
\hline 123 & $\begin{array}{r}\text { B-16-05 06SBBC } \\
\text { [Cabin Spring] }\end{array}$ & 347 & $358-364$ & NA & NA & 80.1 & NA & -15.3 & -12 & -11.3 & $\begin{array}{l}-10.5 \text { to } \\
-11.2\end{array}$ & -78 & $\begin{array}{l}-74.7 \text { to } \\
-78.6\end{array}$ \\
\hline 124 & $\begin{array}{l}\text { A-17-01 07AAA } \\
\text { UNSURV [Duff } \\
\text { Spring] }\end{array}$ & 416 & $404-442$ & NA & 41 & 39.2 & NA & -8.2 & -8.2 & -9.2 & $-9.3^{-9.2 \text { to }}$ & -70 & $\begin{array}{l}-67 \text { to } \\
-70.5\end{array}$ \\
\hline
\end{tabular}

1The same site was sampled in this study and a previous study by the U.S. Geological Survey.

${ }^{2}$ Blasch and others (2006). 


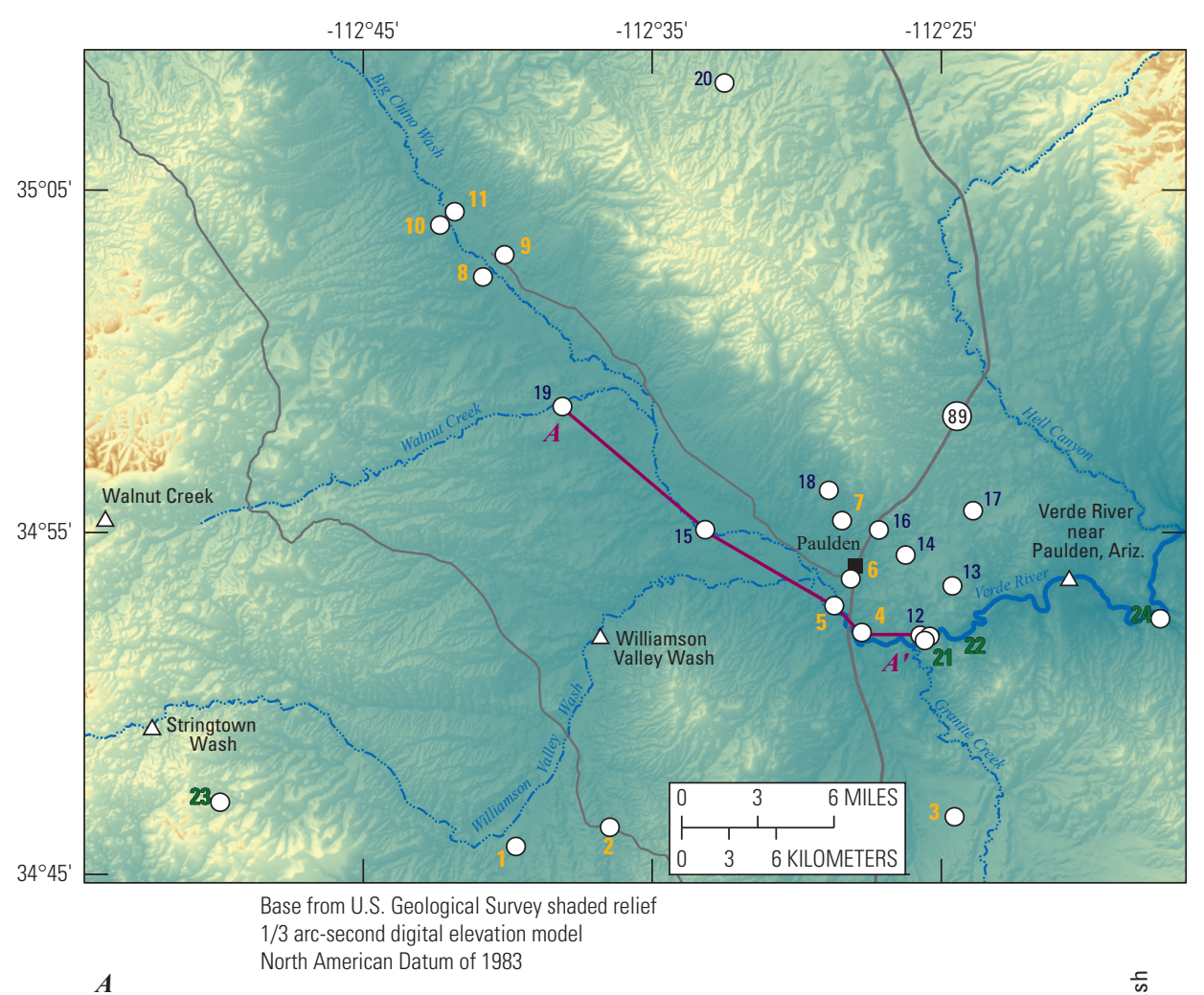

\begin{tabular}{|c|c|c|c|}
\hline & \multicolumn{2}{|c|}{ EXPLANATION } & \multirow[b]{2}{*}{ Line of section } \\
\hline Qbf & asin-fill (Quaternary)—Unconsolidated & \multirow{3}{*}{$\begin{array}{l}A-A \\
-----\end{array}$} & \\
\hline & sediment & & \multirow{2}{*}{$\begin{array}{l}\text { Geologic unit contact-Location } \\
\text { inferred between known well logs } \\
\text { and geophysical sections }\end{array}$} \\
\hline Tbf & $\begin{array}{l}\text { Basin-fill (Tertiary)—Unconsolidated } \\
\text { sediment }\end{array}$ & & \\
\hline Tv & Volcanic rocks (Tertiary) & -ニ- & Fault-Location inferred. Arrows show \\
\hline MDrm & $\begin{array}{l}\text { Redwall Limestone and Martin Formation, } \\
\text { undivided (Mississippian to Middle? } \\
\text { Devonian) }\end{array}$ & 15 & $\begin{array}{l}\text { relative movement } \\
\text { Well and site number-Site name } \\
\text { provided in table } 1\end{array}$ \\
\hline \multirow[t]{2}{*}{$\epsilon b t$} & \multirow{2}{*}{$\begin{array}{l}\text { Bright Angel Shale and Tapeats Sandstone } \\
\text { of Tonto Group, undivided (Middle and } \\
\text { Lower Cambrian) }\end{array}$} & $\Delta$ & Surface-water sampling site and name \\
\hline & & 0 & $\begin{array}{l}\text { Groundwater sampling site and number } \\
\text { - Site number color denotes source. }\end{array}$ \\
\hline \multirow[t]{5}{*}{$X Y$} & Basement rocks (Proterozoic) & & Site names provided in table 1 \\
\hline & Elevation, in feet above North & ${ }^{3} \mathrm{O}$ & Basin-fill aquifer \\
\hline & Vertical Datum of 1988 & ${ }^{14} \bigcirc$ & Carbonate aquifer \\
\hline & $-9,362$ & ${ }^{21} \mathrm{O}$ & Spring \\
\hline & -3 & NS4 & $\begin{array}{l}\text { Geophysical cross section from Macy } \\
\text { and others (2019) }\end{array}$ \\
\hline
\end{tabular}

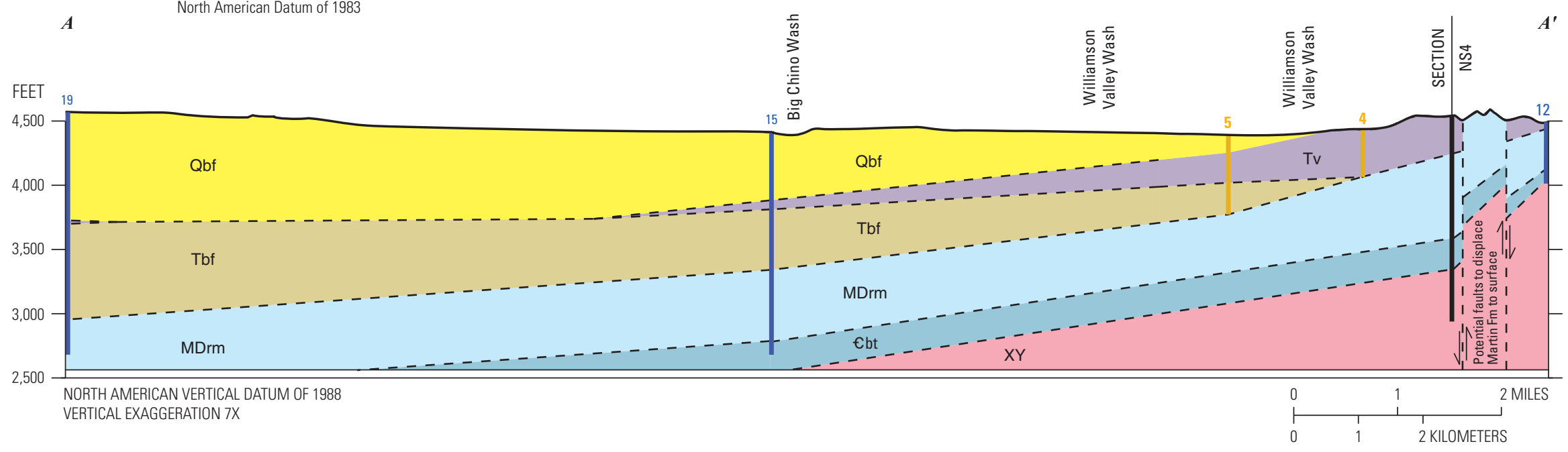

Figure 19. Generalized geologic cross section $A-A^{\prime}$ between wells 19 and 12 utilizing driller's logs and geophysical survey (NS4) from Macy and others (2019) and geologic information from DeWitt and others (2008). Abbreviated geologic names simplified from DeWitt and others (2008). 
value of $54.7 \mathrm{pmc}$. There is an increase in $\delta^{13} \mathrm{C}$ from wells B through $\mathrm{D}(-8.5$ to -5.5 per mil), followed by a decrease at well $\mathrm{E}$ ( -8.2 per mil). Tritium is fairly similar for wells $\mathrm{B}, \mathrm{D}$, and $\mathrm{E}$, ranging from 1.1 to 1.3 tritium units (TU), with uncertainties ranging from 0.4 to $0.6 \mathrm{TU}$. Well $\mathrm{C}$ has a lower tritium value of $0.5 \mathrm{TU}$, with an uncertainty of $0.6 \mathrm{TU}$. The age of the basin-fill waters from Wirt and DeWitt (2005) indicates similar inputs of modern water throughout the basin-fill and a minor component of modern water present at these sites. The stable isotopic values of the samples decrease from wells B through $\mathrm{D}\left(-9.6\right.$ to -10.2 for $\delta^{18 \mathrm{O} \text { and }}-70$ to -75 for $\left.\delta^{2} \mathrm{H}\right)$ and then remain fairly similar at well $\mathrm{E}\left(-10.3\right.$ for $\left.\delta^{18} \mathrm{O}\right)$ with a slight increase in $\delta^{2} \mathrm{H}(-73)$. The differences in stable isotopic values seem to indicate input from sources with different recharge elevations or seasonality as the water moves downgradient in the basin-fill aquifer beneath Big Chino Valley.

Sites 4 and 6 are also in the basin-fill just south and north of site 5, respectively (fig. 15), and have higher values of tritium and carbon-14, which indicates a contribution of water recharged after 1952. Sites 4, 5, and 6 have general geochemical characteristics similar to other basin-fill samples, including lower concentrations of arsenic and a lower strontium isotopic ratio. Site 5 has noble gas concentrations indicating a higher recharge elevation compared to sites 4 and 6; however, the stable isotopic values are very similar to those at site 6 . Sites 5 and 6 have $\mathrm{R} / \mathrm{Ra}$ values indicating a crustal source of helium, whereas site 4 has an atmospheric source. There may be variability within the basin-fill aquifer that is driven by permeability, and additional sampling density would provide valuable knowledge about the system. Groundwater at site 6 has similar major ion chemistry, arsenic, radiocarbon, and stable isotopic values compared to those for well E from Wirt and DeWitt (2005), which was presented as an integrator of basin-fill chemistry.

The chemistry of the water at the UVS (sites 21 and 22) discharging to a gaining reach of the Verde River represents the evolution and mixing of waters upgradient from the sites. Site 21 (UVS South) discharges on the south side of the Verde River, and site 22 (Greenbie Pool) discharges on the north side. The specific contribution of water to the UVS would require additional samples in the system and geochemical modeling outside the scope of this report. The holistic chemistry of the UVS is presented and then compared with upgradient groundwaters from this study.

Sites 21 and 22 had mixed cation-bicarbonate type water chemistry, low tritium $(0.26$ and $0.47 \mathrm{pCi} / \mathrm{L}$ in 2017 and non-detect in 2018), and a crustal source of He. Other chemical parameters were slightly different between the two sites (table 10). Site 21 groundwater had lower specific conductance (618 to 625 microsiemens per centimeter at 25 degrees Celsius $\left[\mu \mathrm{S} / \mathrm{cm}\right.$ at $\left.25^{\circ} \mathrm{C}\right]$ ) compared with site 22 groundwater (764 to $810 \mu \mathrm{S} / \mathrm{cm}$ ) (table 10). Arsenic was lower at site $21(20.5$ to $23 \mu \mathrm{g} / \mathrm{L})$ compared with site 22 (37.9 to 43.8 $\mu \mathrm{g} / \mathrm{L}$ ). The radiocarbon age was about 3,300 to 3,200 years B.P. for site 21 and slightly older at site 22 (about 4,400 to 4,000 years B.P.) and a $\delta^{13} \mathrm{C}$ range of -7.45 to -7.53 at site
21 and slightly higher $\delta^{13} \mathrm{C}$ range at site $22(-6.25$ to -6.5 per mil). Strontium concentration was similar between sites 21 and 22 and increased between the two sampling events from 340 to $379 \mu \mathrm{g} / \mathrm{L}$ at site 21 and from 300 to $334 \mu \mathrm{g} / \mathrm{L}$ at site 22. Strontium isotopic values at site 21 were 0.71022 to 0.71024 and slightly higher at site 22 (0.71094 to 0.71095$)$. Stable isotopic values for $\delta 18 \mathrm{O}$ were -10.2 to -10.24 at site 21 and lower $(-10.33$ and -10.32$)$ at site 22 ; those for $\delta^{2} \mathrm{H}$ were -74.5 to -74.8 at site 21 and lower at site $22(-75.5$ to -76 per mil). These differences between 21 and 22 indicate slightly older water originating from a higher elevation at site 22 that has interacted with different rock units.

Site 15 , located in the carbonate aquifer beneath the basin-fill, had mixed cation-bicarbonate type water chemistry, lower specific conductance $(593 \mu \mathrm{S} / \mathrm{cm})$ than the UVS, a radiocarbon age of about 2,800 years B.P., a $\delta^{13} \mathrm{C}$ value of -7.85 per mil, low tritium $(0.16 \mathrm{pCi} / \mathrm{L})$, a strontium concentration of $300 \mu \mathrm{g} / \mathrm{L}$, strontium isotopic value of 0.71101 , and stable isotopic values of -10.48 and -76.1 per mil for $\delta^{18} \mathrm{O}$ and $\delta^{2} \mathrm{H}$, respectively (table 10 ). Groundwater at site 15 would need to move through the subsurface for an appreciable distance to reach the UVS and would be expected to become older as it evolved through the system. The UVS water is slightly older (about 3,300 to 3,200 and 4,400 to 4,000 years B.P. for sites 21 and 22, respectively) compared with site 15 water. Physical properties of the subsurface would need to be known to calculate the travel time of water from site 15 to the spring sites and could be explored in future studies to understand whether the system supports an evolution of the water between site 15 and sites 21 and 22 or whether an additional input of other water would be needed to explain the resultant chemistry.

Water from an observation well drilled in 2018 into the carbonate aquifer north of the UVS (site 12) has lower specific conductance $(599 \mu \mathrm{S} / \mathrm{cm})$ and similar chemistry to that of site 15 water, except for the stable isotopes, which have higher values at site 12 (table 10). Water at site 12 may represent another source of groundwater contributing to the Verde River in the gaining reach that was not located at a discrete sampling location at the time of the study (fig. 20).

The water chemistry between sites $13,14,16$, and 18 in the carbonate unit north of the Verde River is similar, in terms of specific conductance ( 810 to $929 \mu \mathrm{S} / \mathrm{cm}$ ), arsenic concentration (37 to $60.3 \mu \mathrm{g} / \mathrm{L}$ ), strontium concentration (280 to $315 \mu \mathrm{g} / \mathrm{L}$ ), strontium isotopic ratios (0.71121 to 0.71154$)$, and groundwater age (about 6,100 to 5,200 years B.P.). The sites had low $\delta^{13} \mathrm{C}(-6.18$ to -6.24 per mil), low stable isotopic ratios of -10.4 to -10.54 and -75.7 to -77.4 per mil for $\delta^{18} \mathrm{O}$ and $\delta^{2} \mathrm{H}$, and very low or nondetectable tritium (table 10). The water chemistry at site 7 is similar to that of the four sites just discussed, and as mentioned earlier, the site is screened in the basin-fill but may have water moving from the carbonate unit beneath Big Black Mesa into the basin-fill near the edge of the basin-fill north of Paulden. The water chemistry of all five sites is generally more similar to that of site 22 compared with site 21 , although the age of the water at site 22 is less 
Table 10. Groundwater chemistry of springs discharging to the Verde River and select groundwater sites.

[Dates shown as month, day, year. Corrected groundwater age uses -12 per mil for $\delta{ }^{13} \mathrm{C}$ soil gas, presented in table $8 . \mu \mathrm{S} / \mathrm{cm}$ at $25^{\circ} \mathrm{C}$, microsiemens per centimeter at 25 degrees Celsius; $\mu \mathrm{g} / \mathrm{L}$, micrograms per liter; B.P., before present; $\mathrm{pCi} / \mathrm{L}$, picocuries per liter; NA, not applicable; MX, mixed cation; R, radiochemistry non-detect]

\begin{tabular}{|c|c|c|c|c|c|c|c|c|c|c|c|}
\hline $\begin{array}{c}\text { Site } \\
\text { number }\end{array}$ & $\begin{array}{l}\text { Sampling } \\
\text { date }\end{array}$ & $\begin{array}{c}\text { Specific } \\
\text { conductance } \\
(\mu \mathrm{S} / \mathrm{cm} \\
\left.\text { at } 25^{\circ} \mathrm{C}\right)\end{array}$ & $\begin{array}{l}\text { Water } \\
\text { type }\end{array}$ & $\begin{array}{c}\text { Arsenic } \\
\text { concen- } \\
\text { tration } \\
(\mu \mathrm{g} / \mathrm{L})\end{array}$ & $\begin{array}{c}\text { Corrected } \\
\text { ground- } \\
\text { water age } \\
\text { (years B.P.) }\end{array}$ & $\begin{array}{c}\delta^{13} \mathrm{C} \\
\text { (per mil) }\end{array}$ & $\begin{array}{l}\text { Tritium } \\
\text { (pCi/L) }\end{array}$ & $\begin{array}{c}\text { Strontium } \\
\text { concen- } \\
\text { tration } \\
(\mu \mathrm{g} / \mathrm{L})\end{array}$ & $\begin{array}{l}{ }^{87} \mathrm{Sr} / 86 \mathrm{Sr} \\
\text { (unitless) }\end{array}$ & $\begin{array}{c}\delta^{180} \\
\text { (per mil) }\end{array}$ & $\begin{array}{c}\delta^{2} \mathrm{H} \\
\text { (per mil) }\end{array}$ \\
\hline \multicolumn{12}{|c|}{ Basin-fill aquifer } \\
\hline 4 & $8 / 22 / 17$ & 570 & $\mathrm{Ca} / \mathrm{Mg}-\mathrm{HCO}_{3}$ & 5.0 & NA & -11.51 & 5.79 & 418 & 0.70904 & -8.76 & -64.6 \\
\hline 5 & $8 / 5 / 15$ & 260 & $\mathrm{MX}-\mathrm{HCO}_{3}$ & 8.1 & 17,233 & -9.81 & 0.29 & 210 & 0.70948 & -10.06 & -73.0 \\
\hline 6 & $7 / 1 / 14$ & 420 & $\mathrm{MX}-\mathrm{HCO}_{3}$ & 10.7 & NA & -8.94 & 2.1 & 353 & 0.70964 & -10.06 & -72.9 \\
\hline 7 & $8 / 22 / 17$ & 868 & $\mathrm{MX}-\mathrm{HCO}_{3}$ & 48.6 & 5,714 & -6.44 & $\mathrm{R}-0.17$ & 341 & 0.71097 & -10.44 & -75.8 \\
\hline \multicolumn{12}{|c|}{ Carbonate aquifer } \\
\hline 12 & $2 / 20 / 18$ & 599 & $\mathrm{MX}-\mathrm{HCO}_{3}$ & 18.7 & 3,056 & -7.45 & 0.51 & 370 & 0.7101 & -10.13 & -74.2 \\
\hline 13 & $2 / 21 / 18$ & 821 & $\mathrm{MX}-\mathrm{HCO}_{3}$ & 37.0 & 5,153 & -6.20 & R 0.03 & 280 & 0.71128 & -10.46 & -75.7 \\
\hline 14 & $6 / 8 / 17$ & 810 & $\mathrm{MX}-\mathrm{HCO}_{3}$ & 51.2 & 5,294 & -6.18 & $\mathrm{R}-0.10$ & 313 & 0.71121 & -10.4 & -76.6 \\
\hline 15 & $4 / 29 / 18$ & 593 & $\mathrm{MX}-\mathrm{HCO}_{3}$ & 19.6 & 2,790 & -7.85 & 0.16 & 300 & 0.71101 & -10.48 & -76.1 \\
\hline 16 & $8 / 23 / 17$ & 851 & $\mathrm{MX}-\mathrm{HCO}_{3}$ & 58.8 & 5,417 & -6.24 & $\mathrm{R}-0.20$ & 315 & 0.71138 & -10.52 & -77.4 \\
\hline 17 & $4 / 29 / 18$ & 709 & $\mathrm{MX}-\mathrm{HCO}_{3}$ & 15.7 & 4,531 & -6.13 & $\mathrm{R}-0.11$ & 160 & 0.71098 & -10.46 & -77.4 \\
\hline 18 & $7 / 1 / 14$ & 929 & $\mathrm{MX}-\mathrm{HCO}_{3}$ & 60.3 & 6,112 & -6.23 & 0.06 & 307 & 0.71154 & -10.54 & -77.2 \\
\hline \multicolumn{12}{|c|}{ Springs } \\
\hline 21 & $6 / 6 / 17$ & 625 & $\mathrm{MX}-\mathrm{HCO}_{3}$ & 23.0 & 3,231 & -7.45 & 0.26 & 379 & 0.71022 & -10.24 & -74.5 \\
\hline 21 & $6 / 11 / 18$ & 618 & $\mathrm{MX}-\mathrm{HCO}_{3}$ & 20.5 & 3,310 & -7.53 & R 0.15 & 340 & 0.71024 & -10.2 & -74.8 \\
\hline 22 & $6 / 6 / 17$ & 810 & $\mathrm{MX}-\mathrm{HCO}_{3}$ & 43.8 & 3,997 & -6.25 & 0.47 & 334 & 0.71094 & -10.33 & -76.0 \\
\hline 22 & $6 / 11 / 18$ & 764 & $\mathrm{MX}-\mathrm{HCO}_{3}$ & 37.9 & 4,424 & -6.50 & R 0.05 & 300 & 0.71095 & -10.32 & -75.5 \\
\hline
\end{tabular}




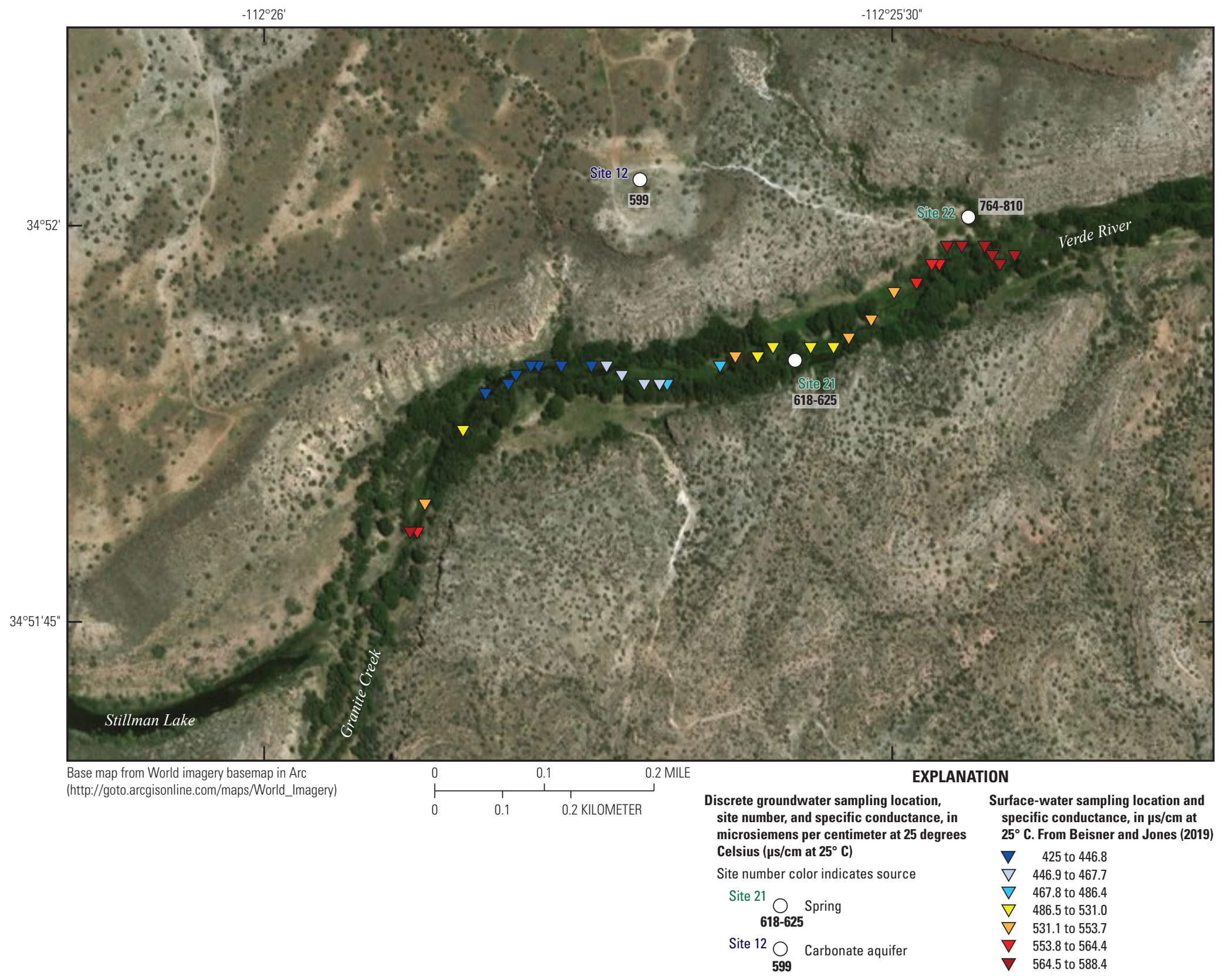

Figure 20. Specific conductance in the Verde River on June 13, 2018. Map image is the intellectual property of Esri and is used herein under license. Copyright $@ 2019$ Esri and its licensors. All rights reserved. 
than the other sites discussed here and indicates an additional contribution of younger water (on the order of thousands of years old- prior than the tritium pulse).

Site 17 is located slightly east of the four wells in the carbonate unit (sites 13, 14, 16, and 18, fig. 4) and compared with those sites, its water is slightly younger in age (similar to that of site 22), lower in arsenic concentration, lower in strontium concentration and strontium isotopic values, but similar in stable isotopic values (table 10). These differences in water chemistry at site 17 may indicate its water is upgradient and evolves as it moves through the subsurface toward other wells in the carbonate unit north of the Verde River, such as site 13. Alternatively, water at site 17 may represent water from a different source and flow path.

Basin-fill aquifer samples collected from sites 4 and 6 near Paulden and the area where the basin-fill pinches out, have distinct chemistry compared with the previously discussed carbonate aquifer samples (table 10). Groundwater in the basin-fill aquifer could represent a component of water mixed with the groundwater in the carbonate aquifer at downgradient sites, but quantification of the component and ultimate fate of groundwater in the basin-fill aquifer could not be constrained with the information from this study.

\section{Surface-Water Chemistry}

Surface-water chemistry along the gaining reach of the Verde River below Granite Creek is assessed in this section. Stable isotopic values from the Verde River near Paulden, Ariz. and Williamson Valley Wash near Paulden, Ariz. streamgages are also assessed in this section for several years of data collection.

\section{Spatial Variation of Water-Quality Properties in Verde River Below Granite Creek}

Water-quality properties (water temperature, dissolved oxygen, $\mathrm{pH}$, and specific conductance) were measured along the Verde River on June 13, 2018, by walking upstream from just below the confluence of Greenbie Pool (site 22) inflow to just below the confluence with Granite Creek. Location, time, and water-quality property values are published in Beisner and Jones (2019). Along the reach downstream from the Granite Creek confluence, specific conductance in the Verde River decreased northward, then increased eastward (fig. 20). Water temperature increased rapidly, then slowly increased following the shift in flow direction of the Verde River. The $\mathrm{pH}$ also increased in accordance with the temperature, then decreased following the temperature stabilization. The specific conductance data indicate possible zones of influence from groundwater inflows along this reach of the Verde River, specifically, three zones of groundwater input may exist, each with a distinct chemical signature, along the Verde River between its confluences with Granite Creek and the Greenbie Pool drainage inflow.
Spatial variability in Verde River discharge and water quality along the gaining reach was assessed in June 2000 by Wirt (2005) and results from that study follow. Discharge increased by approximately $20 \mathrm{ft} 3 / \mathrm{s}$ in a 1-mi stretch of the Verde River downstream from the confluence with Granite Creek. Wirt (2005) found a similar decrease in specific conductance with distance downstream from Granite Creek, followed by an increase in specific conductance starting $920 \mathrm{ft}$ downstream from Granite Creek. The specific conductance of the Verde River was also less than that of the discrete spring input locations. Specific conductance in the Verde River stabilized approximately 5,000 ft downstream from the Granite Creek confluence, remained stable farther downstream, and was comparable to the specific conductance measured at the Verde River near Paulden, Ariz. streamgage (09503700) (U.S. Geological Survey, 2019).

Water temperature increased rapidly with distance at the beginning of the gaining reach of the Verde River and then stabilized farther downstream. The $\mathrm{pH}$ also increased rapidly with the increase in temperature and decreased when the temperature reached a more consistent value. Stable isotopes $\left(\delta^{18} \mathrm{O}\right.$ and $\left.\delta^{2} \mathrm{H}\right)$ decreased rapidly in the first $1,700 \mathrm{ft}$ of the gaining reach of the Verde River, then decreased slowly throughout the rest of the gaining reach. The reporting level for arsenic in the Verde River samples was $<100 \mu \mathrm{g} / \mathrm{L}$, so changes in arsenic along the stretch were not documented by Wirt (2005). Additional studies investigating the gaining reach of the Verde River would be valuable, and arsenic could serve as a useful tracer of changes in groundwater source.

\section{General Water Chemistry at Verde River Near Paulden}

The water-quality properties were measured at the USGS Verde River near Paulden, Ariz. streamgage (09503700) were collected in June of 2017 and 2018 (U.S. Geological Survey, 2019). Water temperature was $22.3{ }^{\circ} \mathrm{C}$ and $24{ }^{\circ} \mathrm{C}$, pH was 8.2 and 8.4 , specific conductance was 648 and $642 \mu \mathrm{S} / \mathrm{cm}$, and the dissolved oxygen concentration was 8.4 and $9.1 \mathrm{mg} / \mathrm{L}$ for 2017 and 2018 , respectively. Water type was mixed cationbicarbonate type water. Nutrient concentrations were low; ammonia as nitrogen $(\mathrm{N})$ concentration was 0.02 to $0.04 \mathrm{mg} / \mathrm{L}$, nitrite as $\mathrm{N}$ concentration was $0.006 \mathrm{mg} / \mathrm{L}$, nitrate as $\mathrm{N}$ concentration was 0.525 to $0.612 \mathrm{mg} / \mathrm{L}$, and orthophosphate as phosphate concentration was $0.015 \mathrm{mg} / \mathrm{L}$. Arsenic concentration at the Verde River near Paulden, Ariz. streamgage (09503700) was 27 and $26.1 \mu \mathrm{g} / \mathrm{L}$ in 2017 and 2018 , respectively. Strontium concentration was $290 \mu \mathrm{g} / \mathrm{L}$ and strontium isotopic ratio was 0.71016 in 2018, which is a slightly lower compared to the ratio at UVS discharging upgradient to the Verde River (sites 21 and 22, fig. 11). No aquatic life standards were exceeded for analytes measured at this site (table 2). 


\section{Analysis of Stable Isotopes of Surface Water}

Stable isotopes $\left(\delta^{18} \mathrm{O}\right.$ and $\left.\delta^{2} \mathrm{H}\right)$ have been measured on a regular basis at the Verde River near Paulden, Ariz. (09503700) from 2009 to 2019 (fig. 21). Samples were primarily collected during base-flow conditions, but some samples are associated with elevated discharge events. Values ranged from -9.88 to -10.2 per mil and from -72 to -76.3 per mil for $\delta^{18} \mathrm{O}$ and $\delta^{2} \mathrm{H}$, respectively, with an average and standard deviation of $-10.04 \pm 0.08$ and $-73.8 \pm 0.93$ for $\delta^{18} \mathrm{O}$ and $\delta^{2} \mathrm{H}$, respectively. These values are similar to those for samples collected by the USGS prior to this study ( -10 and -71.5 on July 3, 1991 [Wirt and Hjalmarson, 2000] and -10.05 and -73.2 on June 13, 2000 [Blasch and others, 2006]). All samples plot to the right of the GMWL, and the samples farthest from this line represent evaporated water (fig. 22).

A Mann-Kendall trend test for the stable isotope values from 59 samples collected between 2009 and 2019 had a test statistic (S) and tau value of 117 and 0.07 for $\delta^{18} \mathrm{O}$ and
145 and 0.09 for $\delta^{2} \mathrm{H}$, with associated p-values of 0.44 and 0.34 , respectively. The Mann-Kendall test results indicated no significant monotonic trend exists in stable isotope values between 2009 and 2019 at the Verde River near Paulden, Ariz. streamgage (09503700).

Stable isotope samples were collected at the Williamson Valley Wash near Paulden, Ariz. streamgage (09502800) during times of measurable discharge at the streamgage between 2016 and 2018 (fig. 23). Values ranged from -9.62 to -10.58 per mil and from -71.2 to -74.3 per mil for $\delta^{18} \mathrm{O}$ and $\delta^{2} \mathrm{H}$, respectively. There was a decrease in $\delta^{18} \mathrm{O}$ with an increase in discharge in early 2017 and an increase in $\delta 18 \mathrm{O}$ over time during a stable flow event in early 2018 . The samples from the 2018 water year show a deviation from the meteoric water line, indicating potential evaporation (fig. 24). (A water year is the 12-month period from October 1 to September 30 of the following year and is designated by the calendar year in which it ends.)

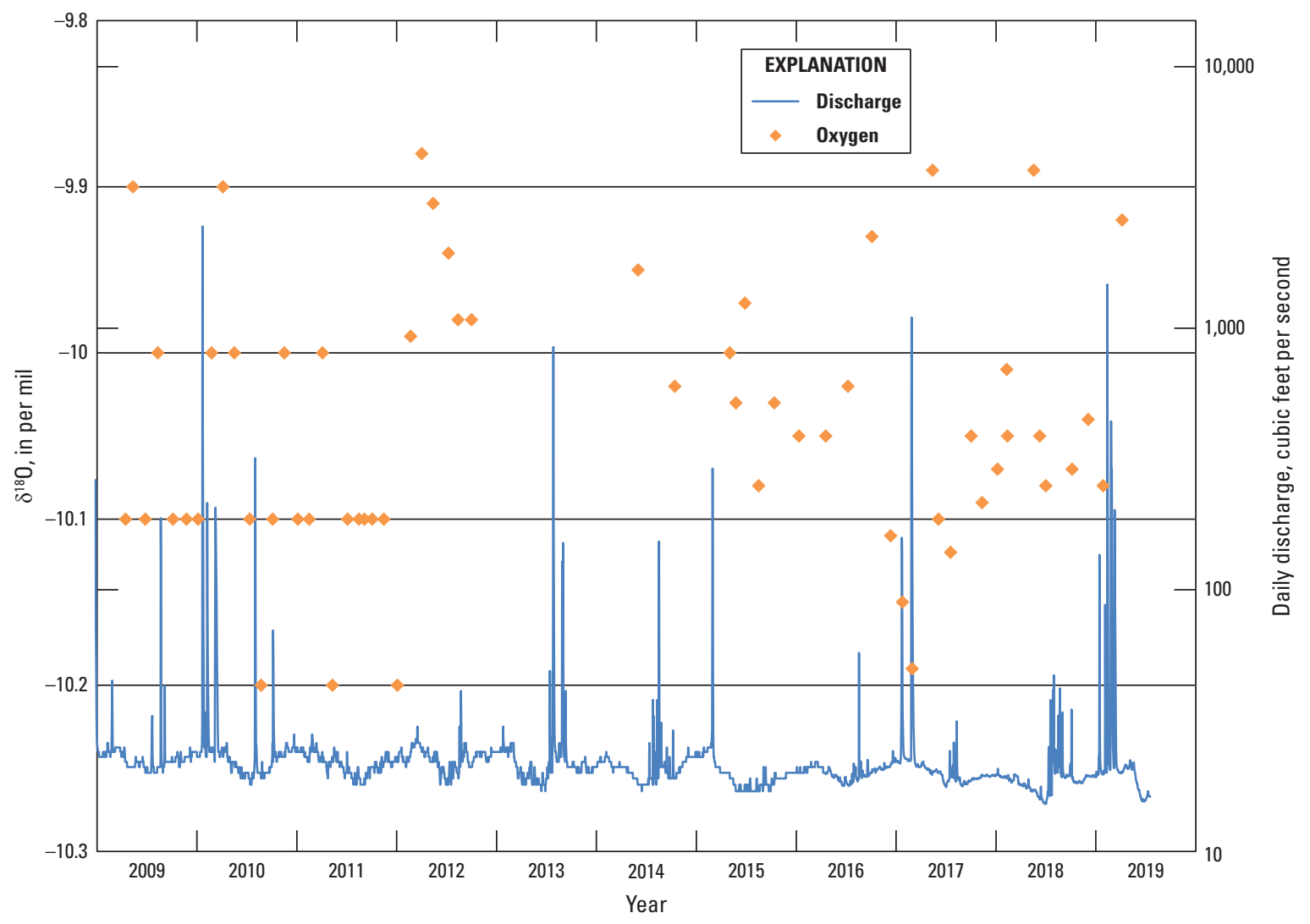

Figure 21. Stable isotopes of oxygen $\left(\delta^{180}\right)$ over time relative to daily discharge at Verde River near Paulden, Arizona (streamgage 09503700) (U.S. Geological Survey, 2019). 


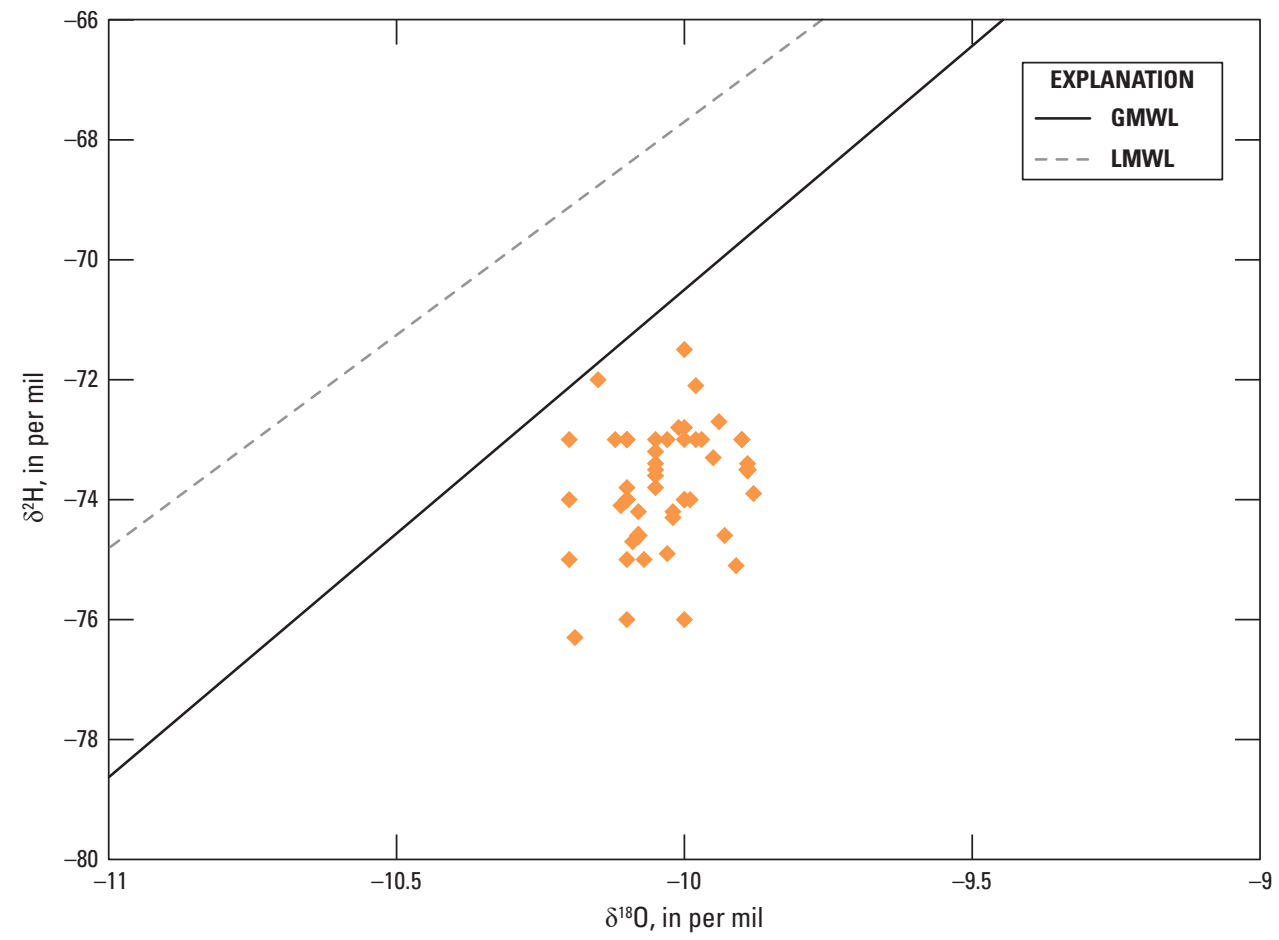

Figure 22. Stable isotope ratio of oxygen $\left(\delta^{18} 0\right)$ versus stable isotope ratio of hydrogen $\left(\delta^{2} \mathrm{H}\right)$ for the Verde River near Paulden, Arizona. Solid black line is the global meteoric water line (GMWL) from Craig (1961) and the dashed gray line is the local meteoric water line (LMWL) from Beisner and others (2016).

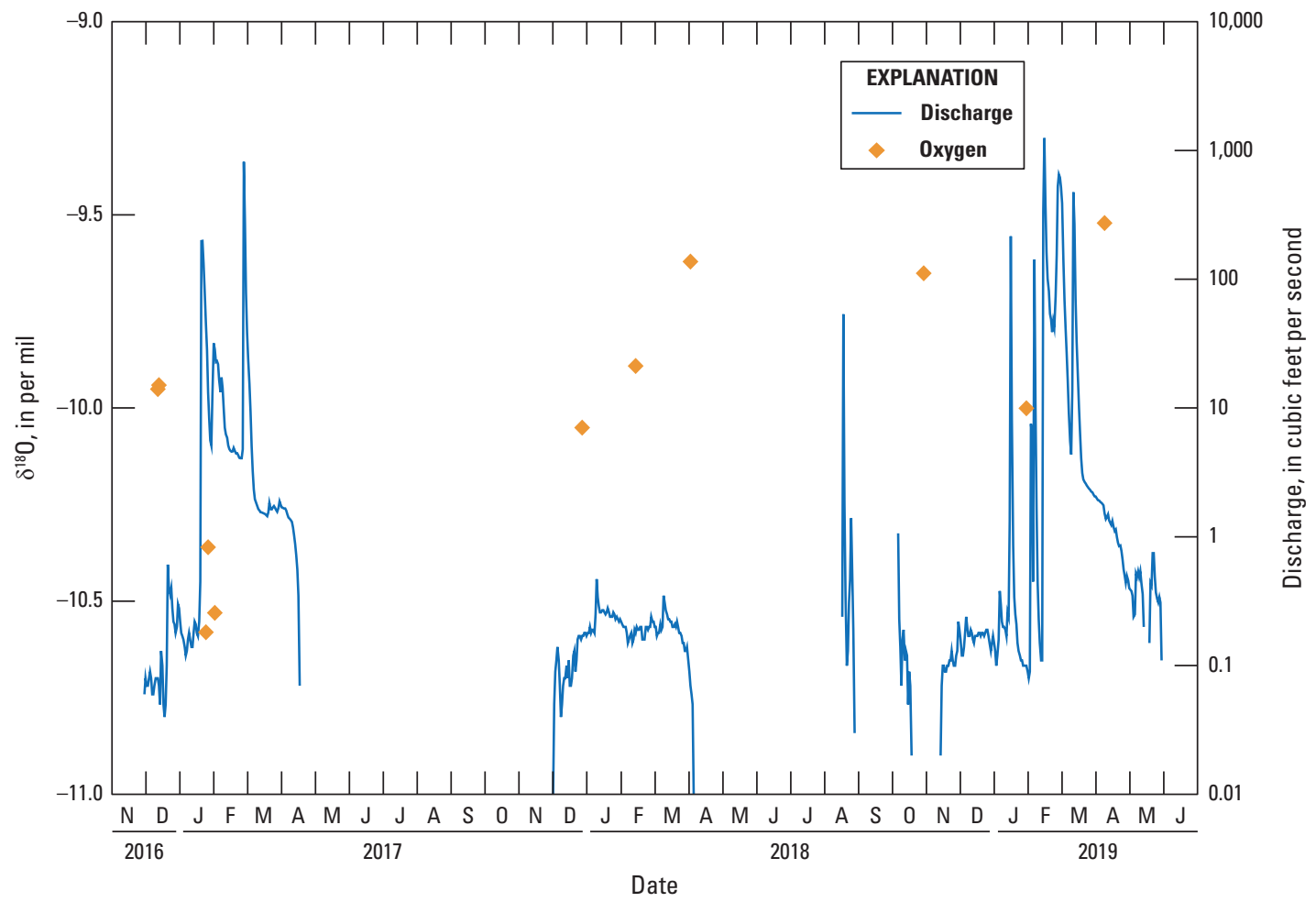

Figure 23. Stable isotopes of oxygen $\left(\delta^{18} 0\right)$ over time relative to daily discharge at Williamson Valley Wash near Paulden, Arizona (streamgage 09502800) (U.S. Geological Survey, 2019). 


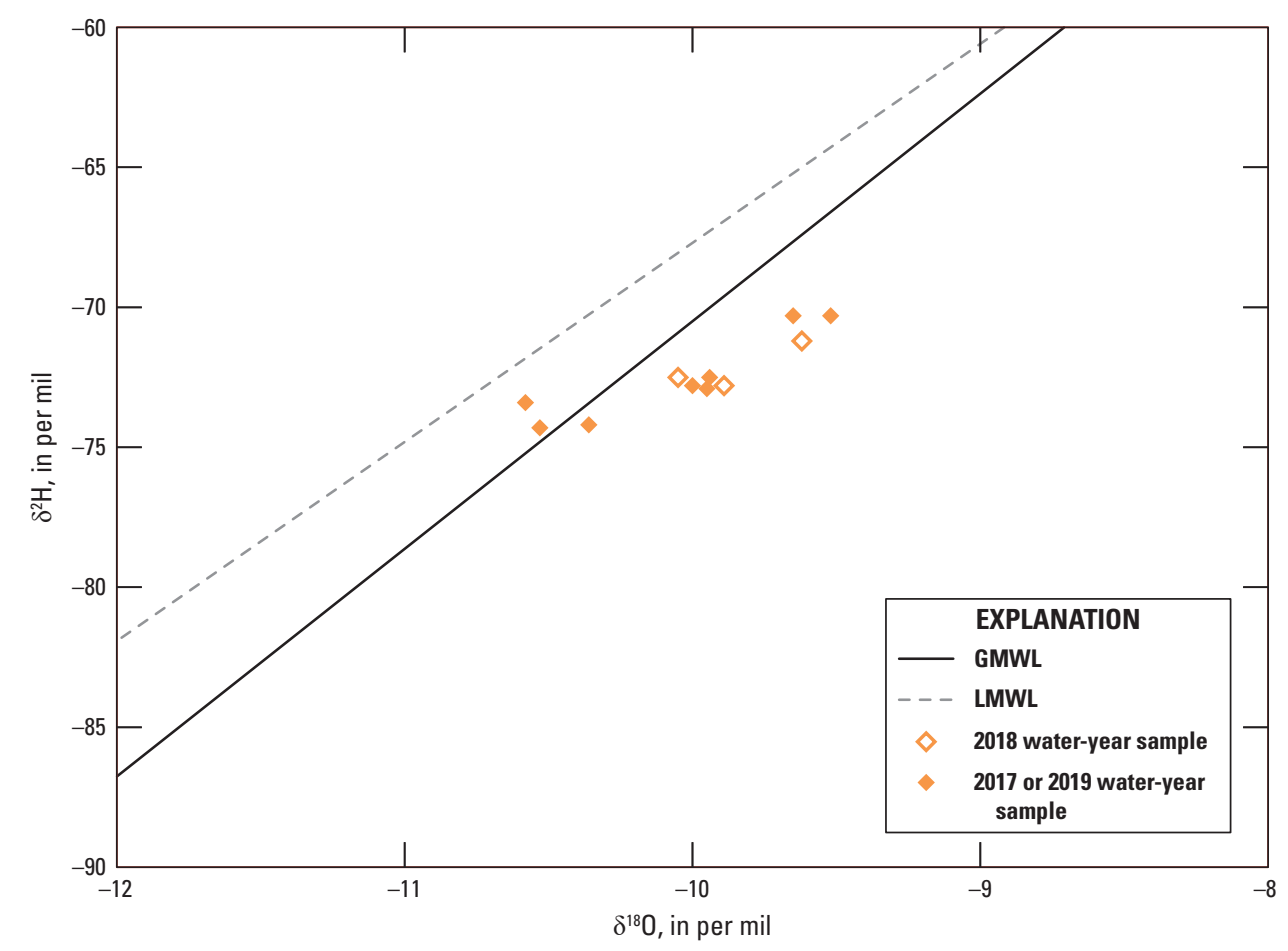

Figure 24. Stable isotope ratio of oxygen $\left(\delta^{18} 0\right)$ versus stable isotope ratio of hydrogen $\left(\delta^{2} \mathrm{H}\right)$ for Williamson Valley Wash near Paulden, Arizona. Solid black line is the global meteoric water line (GMWL) from Craig (1961) and the dashed gray line is the local meteoric water line (LMWL) from Beisner and others (2016).

\section{Summary}

Geochemical characterization of groundwater in the Big Chino subbasin of Arizona was conducted by the U.S. Geological Survey, in cooperation with the City of Prescott, the Town of Prescott Valley, and Salt River Project, to understand groundwater evolution through the study area and the source of water to springs along the gaining reach of the Verde River just downstream from its confluence with Granite Creek. Samples were collected between 2011 and 2018 in groundwater from basin-fill and carbonate aquifers and at selected springs, including two discrete springs discharging along the gaining reach of the Verde River.

Five newly installed monitoring wells completed in the carbonate aquifer were sampled in 2018 and include the first known geochemical data for carbonate groundwater beneath the basin-fill in the Big Chino subbasin downgradient from Walnut Creek near Paulden, Ariz., as well as for other areas in the study without previous data.

Groundwater samples were collected and analyzed for major ions, arsenic, nutrients, stable isotopes of oxygen and hydrogen $\left(\delta^{18} \mathrm{O}\right.$ and $\left(\delta^{2} \mathrm{H}\right)$, strontium isotopes $\left({ }^{87} \mathrm{Sr} / 86 \mathrm{Sr}\right)$, carbon-14, stable isotope of carbon $\left(\delta^{13} \mathrm{C}\right)$, and noble gases. Samples were collected according to U.S. Geological Survey protocols. Radiocarbon age was determined using the revised Fontes and Garnier model in NETPATH using both -12 and -18 per mil for soil gas estimates.
Significant differences between groundwater in the basinfill and carbonate aquifers were driven primarily by higher $\mathrm{pH}$, tritium, and $\delta^{18} \mathrm{O}$ and $\delta^{2} \mathrm{H}$ in the basin-fill aquifer samples and by higher values of specific conductance, calcium, sodium, bicarbonate, fluoride, and arsenic in the carbonate aquifer samples. All but one sample from the carbonate aquifer and two from the basin-fill aquifer exceeded the U.S. Environmental Protection Agency (EPA) drinking water standard for arsenic of 10 micrograms per liter. The two basin-fill samples with high arsenic had geochemical characteristics of water in the carbonate aquifer and may represent water that had moved through carbonate units before moving into basin-fill material. The source of the groundwater in contact with carbonate material is unknown, but could be groundwater within the mountain block adjacent to the basin-fill (such as Big Black Mesa and the Juniper Mountains). One sample from the basin-fill aquifer exceeded the EPA drinking water standard for fluoride of 4 milligrams per liter and one sample from the carbonate aquifer exceeded the EPA secondary drinking water standard of 2 milligrams per liter.

Tritium provided an indication of groundwater with a component of modern water (recharged after the early 1950s). Groundwater with low values of tritium $(<0.6$ picocuries per liter) had carbon-14 values less than 40-percent modern carbon, while samples with higher values of tritium ( $>1.3$ picocuries per liter) had carbon-14 values greater than 40-percent modern carbon. The youngest groundwater sampled for this study was located in the basin-fill near Williamson Valley and Granite Creek in the southern part of the study area. 
Old groundwater was present in the study area, with one sample potentially representing water from a previous climate (on the order of $>30,000$ years before present [B.P.] based on radiocarbon age). Three other sites with old groundwater in the study area ranged in age from about 17,200 to 8,500 years B.P. and included two samples from the basin-fill aquifer and one sample from the carbonate aquifer. Six groundwater samples had similar radiocarbon ages, with corrected values ranging from about 6,000 to 1,000 years old. Another group of groundwater samples - including the two springs discharging along the gaining reach of the Verde River and two newly installed monitoring wells in the carbonate aquiferhad radiocarbon ages that were unresolvable when using -18 per mil for soil gas and ages ranging from about 4,400 to 2,800 years B.P. when using -12 per mil for soil gas.

Temperature, $\mathrm{pH}$, and specific conductance varied with distance along the gaining reach of the Verde River, indicating multiple zones of groundwater input. These changes were also observed in a previous study conducted in 2000 , which also included $\delta^{18} \mathrm{O}$ and $\delta^{2} \mathrm{H}$ analysis. Surface-water samples for $\delta^{18} \mathrm{O}$ and $\delta^{2} \mathrm{H}$ have been collected at the Verde River near Paulden, Ariz. streamgage (09503700) during discharge measurements made since 2009, and a trend analysis of the data indicated no significant trend exists for the 10 -year period of record.

This study represents a geochemical analysis of groundwater from specific locations collected between 2011 and 2018 and will provide valuable information to compare with future groundwater chemistry data. Additional groundwater samples from the carbonate aquifer beneath the basin-fill up and downgradient from Walnut Creek would provide valuable information to understand groundwater evolution along the Big Chino subbasin. Groundwater-sampling locations on Big Black Mesa are limited, and additional geochemical data from that area would also be beneficial.

\section{References Cited}

Aeschbach-Hertig, W., Peeters, F., Beyerle, U., and Kipfer, R., 1999, Interpretation of dissolved atmospheric noble gases in natural waters: Water Resources Research, v. 35, no. 9, p. 2779-2792. [Also available at https://doi.org/10.1029/1999WR900130.]

Aeschbach-Hertig, W., Peeters, F., Beyerle, U., and Kipfer, R., 2000, Palaeotemperature reconstruction from noble gases in ground water taking into account equilibration with entrapped air: Nature, v. 405, p. 1040-1044. [Also available at https://doi.org/10.1038/35016542.]

Anderson, R.S., Betancourt, J.L., Mead, J.I., Hevly, R.H., and Adam, D.P., 2000, Middle- and lateWisconsin paleobotanic and paleoclimatic records from the southern Colorado Plateau, USA: Palaeogeography, Palaeoclimatology, Palaeoecology, v. 155 , no. 1-2, p. 31-57. [Also available at https://doi.org/10.1016/S0031-0182(99)00093-0.]
Arizona Department of Water Resources [ADWR], 2019, Groundwater hydrology in the Verde River Basin in Arizona Department of Water Resources database, p. 240-315, accessed May 26, 2020, at https://infoshare.azwater.gov/ docushare/dsweb/Get/Document-10430/Volume_5 Final.pdf.

ASTM, 2016, ASTM D5072-09-Standard test method for radon in drinking water: West Conshohocken, Pa., ASTM International, accessed August 22, 2019, at https://doi.org/ 10.1520/D5072-09R16.

Ballentine, C.J., and Hall, C.M., 1999, Determining paleotemperature and other variables by using an error-weighted, nonlinear inversion of noble gas concentrations in water: Geochimica et Cosmochimica Acta, v. 63, no. 16, p. 2315-2336. [Also available at https://doi.org/10.1016/S0016-7037(99)00131-3.]

Bayer, R., Schlosser, P., Bonisch, G., Rupp, H., Zaucker, F., and Zimmek, G., 1989, Performance and blank components of a mass spectrometric system routine measurement of helium isotopes and tritium by ${ }^{3} \mathrm{He}$ ingrowth method: Heidelberg, Sitzungsberichte der Heidelberger Akademie der Wissenschaften Mathematisch-naturwissenschaftliche Klasse [Proceedings of the Heidelberg Academy of Sciences Mathematics and Natural Sciences Class], Springer Verlag, p. 241-279.

Beisner, K.R., Gardner, W.P., and Hunt, A.G., 2018, Geochemical characterization and modeling of regional groundwater contributing to the Verde River, Arizona between Mormon Pocket and the USGS Clarkdale gage: Journal of Hydrology (Amsterdam), v. 564, p. 99-114. [Also available at https://doi.org/10.1016/j.jhydrol.2018.06.078.]

Beisner, K.R., and Jones, C.J., 2019, Water quality parameters in the Verde River below Granite Creek June 2018, U.S. Geological Survey data release, https://doi.org/10.5066/ P909LD47.

Beisner, K.R., Paretti, N.V., and Tucci, R.S., 2016, Analysis of stable isotope ratios $\left(\delta^{18} \mathrm{O}\right.$ and $\left.\delta^{2} \mathrm{H}\right)$ in precipitation of the Verde River watershed, Arizona, 2003 through 2014: U.S. Geological Survey Open-File Report 2016-1053, 11 p. [Also available at https://doi.org/10.3133/ofr20161053.]

Beisner, K.R., Tillman, F.D., Anderson, J.R., Antweiler, R.C., and Bills, D.J., 2017, Geochemical characterization of groundwater discharging from springs north of the Grand Canyon, Arizona, 2009-2016: U.S. Geological Survey Scientific Investigations Report 2017-5068, 58 p. [Also available at https://doi.org/10.3133/sir20175068.]

Beisner, K.R., Tucci, R., and Jones, C.J., 2019, Carbon and strontium isotopic data for rock, soil, and soil gas from the Big Chino sub-basin, Arizona: U.S. Geological Survey data release, https://doi.org/10.5066/P9HMZNIK. 
Bills, D.J., Flynn, M.E., and Monroe, S.A., 2007, Hydrogeology of the Coconino Plateau and adjacent areas, Coconino and Yavapai Counties, Arizona (ver. 1.1, March 2016): U.S. Geological Survey Scientific Investigations Report 2005-5222, 101 p., 4 pls. [Also available at https://dx.doi.org/10.3133/sir20055222.]

Blasch, K.W., Hoffman, J.P., Graser, L.F., Bryson, J.R., and Flint, A.L., 2006, Hydrogeology of the upper and middle Verde River watersheds, central Arizona: U.S. Geological Survey Scientific Investigations Report 2005-5198, 102 p., 3 pls.

Bullen, T.D., Krabbenhoft, D., and Kendall, C., 1996, Kinetic and mineralogic controls on the evolution of groundwater chemistry and ${ }^{87} \mathrm{Sr} / 86 \mathrm{Sr}$ in a sandy silicate aquifer, northern Wisconsin, USA: Geochimica et Cosmochimica Acta, v. 60, no. 10, p. 1807-1821. [Also available at https://doi.org/10.1016/0016-7037(96)00052-X.]

Cey, B.D., 2009, On the accuracy of noble gas recharge temperatures as a paleoclimate proxy: Journal of Geophysical Research, v. 114, no. D4, 9 p. [Also available at https://doi.org/10.1029/2008JD010438.]

Clarke, K.R., Gorley, R.N., Somerfield, P.J., and Warwick, R.M., 2014, Ordination of samples by multi-dimensional scaling (MDS), chap. 5 of Change in marine communitiesAn approach to statistical analysis and interpretation (3d ed.): Devon, U.K., PRIMER-E Ltd., variously paged.

Conway, F.M., Ferrill, D.A., Hall, C.M., Morris, A.P., Stamatakos, J.A., Connor, C.B., Halliday, A.N., and Condit, C., 1997, Timing of basaltic volcanism along the Mesa Butte Fault in the San Francisco Volcanic Field, Arizona, from ${ }^{40} \mathrm{Ar} /{ }^{39} \mathrm{Ar}$ dates - Implications for longevity of cinder cone alignments: Journal of Geophysical Research, v. 102, no. B1, p. 815-824.

Craig, H., 1961, Isotopic variations in meteoric waters: Science, v. 133, no. 3465, p. 1702-1703. [Also available at https://doi.org/10.1126/science.133.3465.1702.]

Damon, P.E., Shafiqullah, M., and Leventhal, J.S., 1974, K-Ar chronology for the San Francisco volcanic field and rate of erosion of the Little Colorado River, in Karlstrom, T.N.V., Swann, G.A., and Eastwood, R.L., eds., Geology of northern Arizona, with notes on archaeology and paleoclimate, part 1-Regional studies: Geological Society of American Rocky Mountain Section Meeting, Flagstaff, Ariz., p. 221-235.

DeWitt, E., Langenheim, V., Force, E., Vance, R.K., Lindberg, P.A., and Driscoll, R.L., 2008, Geologic map of the Prescott National Forest and the headwaters of the Verde River, Yavapai and Coconino Counties, Arizona: U.S. Geological Survey Scientific Investigations Map 2996, scale 1: 100,000, 100-p. pamphlet.
DeWitt, E., Langenheim, V.E., and Wirt, L., 2005, Geologic framework, chap. B of Wirt, L., DeWitt, E., and Langenheim, V.E., eds., Geologic framework of aquifer units and ground-water flowpaths, Verde River headwaters, north-central Arizona: U.S. Geological Survey Open-File Report 2004-1411, 31 p.

Domenico, P.A., and Schwartz, F.A., 1990, Physical and chemical hydrogeology: New York, Wiley, p. 824.

Eastoe, C.J., Watts, C.J., Ploughe, M., and Wright, W.E., 2012, Future use of tritium in mapping pre-bomb groundwater volumes: Ground Water, v. 50, no. 1, p. 87-93. [Also available at https://doi.org/10.1111/j.1745-6584.2011.00806.x.]

Ewing, D.B., Osterberg, J.C., and Talbot, R.W., 1994, Groundwater study of the Big Chino Valley-Hydrology and hydrogeology: Bureau of Reclamation Technical Report, Denver, Colorado, v. 1-2, 8 p., 6 app.

Fishman, M.J., ed., 1993, Methods of analysis by the U.S. Geological Survey National Water Quality LaboratoryDetermination of inorganic and organic constituents in water and fluvial sediments: U.S. Geological Survey OpenFile Report 93-125, 217 p., accessed December 12, 2016, at https://doi.org/10.3133/ofr93125.

Fishman, M.J., and Friedman, L.C., 1989, Methods for determination of inorganic substances in water and fluvial sediments: U.S. Geological Survey Techniques of Water-Resources Investigations, book 5, chap. A1, 545 p., accessed December 12, 2016, at https://doi.org/10.3133/ twri05A1.

Freethy, G.W., and Anderson, T.W., 1986, Predevelopment hydrologic conditions in the alluvial basins of Arizona and adjacent parts of California and New Mexico: U.S. Geological Survey Hydrologic Investigations Atlas HA-664, 3 sheets, scale 1:500,000.

Frost, C.D., and Toner, R.N., 2004, Strontium isotopic identification of water-rock interaction and ground water mixing: Ground Water, v. 42, no. 3, p. 418-432. [Also available at https://doi.org/10.1111/j.1745-6584.2004.tb02689.x.]

Garbarino, J.R., Kanagy, L.K., and Cree, M.E., 2006, Determination of elements in natural-water, biota, sediment, and soil samples using collision/reaction cell inductively coupled plasma-mass spectrometry: U.S. Geological Survey Techniques and Methods, book 5, chap. B1, 88 p., accessed December 12, 2016, at https://pubs.usgs.gov/tm/ 2006/tm5b1/.

Gootee, B.F., Ferguson, C.A., Spencer, J.E., and Cook, J.P., 2011, Geologic map of the Chino Valley north 7.5' quadrangle, Yavapai County, Arizona: Arizona Geological Survey Digital Geologic Map DGM-80, scale 1:24,000. 
HabiMap Arizona, 2019, Arizona biotic communities [State Wildlife Action Plan]: Arizona Game and Fish Department database, accessed December 13, 2019, at http://www.habimap.org/.

Han, L.-F., and Plummer, L.N., 2013, Revision of Fontes $\&$ Garnier's model for the initial ${ }^{14} \mathrm{C}$ content of dissolved inorganic carbon used in groundwater dating: Chemical Geology, v. 351, p. 105-114. [Also available at https://doi.org/10.1016/j.chemgeo.2013.05.011.]

Han, L.-F., and Plummer, L.N., 2016, A review of singlesample-based models and other approaches for radiocarbon dating of dissolved inorganic carbon in groundwater: EarthScience Reviews, v. 152, p. 119-142. [Also available at https://doi.org/10.1016/j.earscirev.2015.11.004.]

Han, L.-F., Plummer, L.N., and Aggarwal, P., 2012, A graphical method to evaluate predominant geochemical processes occurring in groundwater systems for radiocarbon dating: Chemical Geology, v. 318-319, p. 88-112. [Also available at https://doi.org/10.1016/j.chemgeo.2012.05.004.]

Helsel, D.R., 2012, Statistics for censored environmental data using Minitab® and R 2nd ed.: Hoboken, N. J., John Wiley \& Sons, Inc., 324 p.

Helsel, D.R., 2016, Calculating Uscores in R: Practical Stats web page, accessed January 9, 2017, at https://www.practicalstats.com/nada/downloads_files/.

Hunt, A.G., 2015, Noble Gas Laboratory's standard operating procedures for the measurement of dissolved gas in water samples: U.S. Geological Survey Techniques and Methods, book 5, chap. A11, 22 p., [Also available at https://doi.org/ 10.3133/tm5A11.]

Johnson, R.H., DeWitt, E., Wirt, L., Manning, A.H., and Hunt, A.G., 2012, Using geochemistry to identify the source of groundwater to Montezuma Well, a natural spring in Central Arizona, USA - Part 2: Environmental Earth Sciences, v. 67, no. 6, p. 1837-1853. [Also available at https://doi.org/10.1007/s12665-012-1844-3.]

Jones, C.J.R., Springer, A.E., Tobin, B.W., Zappitello, S.J., and Jones, N.A., 2017, Characterization and hydraulic behaviour of the complex karst of the Kaibab Plateau and Grand Canyon National Park, USA, in Parise, M., Gabrovsek, F., and Ravbar, N., eds., Advances in Karst Research - Theory, Fieldwork and Applications: Geological Society of London, Special Publications 466, p. 237-260. [Also available at https://doi.org/10.1144/SP466.5.]

Kennedy, J.R., Kahler, L.M., and Read, A.M., 2019, Aquifer storage change and storage properties, 2010-2017, in the Big Chino subbasin, Yavapai County, Arizona: U.S. Geological Survey Scientific Investigations Report 2019-5060, 39 p. [Also available at https://doi.org/ 10.3133/sir20195060.]
Knauth, L.P., and Greenbie, M., 1997, Stable isotope investigation of ground water-surface water interactions in the Verde River headwaters area, report to the Arizona Department of Water Resources: Arizona State University Department of Geology report in fulfillment of Arizona Water Protection Fund Grant 95-001, 28 p.

Krieger, M.H., 1965, Geology of the Prescott and Paulden quadrangles, Arizona: U.S. Geological Survey Professional Paper 467, 127 p., 5 pls. [Also available at https://doi.org/10.3133/pp467.]

Langenheim, V.E., DeWitt, E., and Wirt, L., 2005a, Geophysical framework based on analysis of aeromagnetic and gravity data, Verde River headwaters, northcentral Arizona, chap. C of Wirt, L., DeWitt, E., and Langenheim, V.E., eds., Geologic framework of aquifer units and ground-water flowpaths, Verde River headwaters, north-central Arizona: U.S. Geological Survey Open-File Report 2004-1411, variously paged.

Langenheim, V.E., DeWitt, E., and Wirt, L., 2005b, Preliminary geophysical framework of the upper and middle Verde River watershed, Yavapai County, Arizona: U.S. Geological Survey Open-File Report 2005-1154, 43 p.

Langenheim, V.E., DeWitt, E., and Wirt, L., 2005c, Geophysical framework based on analysis of aeromagnetic and gravity data, upper and middle Verde River watershed, Yavapai County, Arizona: U.S. Geological Survey Scientific Investigations Report 2005-5278, 25 p., 1 pl.

Lee, J.Y., and Hahn, J.S., 2006, Characterization of groundwater temperature obtained from the Korean national groundwater monitoring stations-Implications for heat pumps: Journal of Hydrology (Amsterdam), v. 329, no. 3-4, p. 514-526. [Also available at https://doi.org/10.1016/j.jhydrol.2006.03.007.]

Levings, G.W., and Mann, L.J., 1980, Maps showing groundwater conditions in the upper Verde River area, Yavapai and Coconino Counties, Arizona, 1978: U.S. Geological Survey Water-Resources Investigations Open-File Report 80-726, 2 sheets, scale 1:250,000.

Lucas, L.L., and Unterweger, M.P., 2000, Comprehensive review and critical evaluation of the half-life of tritium: Journal of Research of the National Institute of Standards and Technology, v. 105, no. 4, p. 541-549.

Macy, J.P., Gungle, B., and Mason, J.P., 2019, Characterization of Big Chino subbasin hydrogeology near Paulden, Arizona, using controlled source audio-frequency magnetotelluric surveys: U.S. Geological Survey Scientific Investigations Report 2019-5082, 39 p. [Also available at https://doi.org/10.3133/sir20195082.]

Manning, A.H., 2009, Ground-water temperature, noble gas, and carbon isotope data from the Española Basin, New Mexico: U.S. Geological Survey Scientific Investigations Report 2008-5200, 69 p. [Also available at https://doi.org/10.3133/sir20085200.] 
Manning, A.H., and Solomon, D.K., 2003, Using noble gases to investigate mountain-front recharge: Journal of Hydrology (Amsterdam), v. 275, no. 3-4, p. 194-207. [Also available at https://doi.org/10.1016/S0022-1694(03)00043-X.]

Mueller, D.K., and Titus, C.J., 2005, Quality of nutrient data from streams and ground water sampled during water years 1992-2001: U.S. Geological Survey Scientific Investigations Report 2005-5106, 27 p. [Also available at https://pubs.usgs.gov/sir/2005/5106/pdf/sir2005-5106.pdf.].

Muller, A.B., and Mayo, A.L., 1986, ${ }^{13}$ C variation in limestone on an aquifer-wide scale and its effects on groundwater ${ }^{14} \mathrm{C}$ dating models: Radiocarbon, v. 28 , no. 3, p. 1041-1054. [Also available at https://doi.org/10.1017/S0033822200020099.]

Oksanen, J., Blanchet, F.G., Friendly, M., Kindt, R., Legendre, P., McGlinn, D., Minchin, P.R., O’Hara, R.B., Simpson, G.L., Solymos, P., Henry, M., Stevens, H., Szoecs, E., and Wagner, H., 2016, Package 'vegan'-Community ecology package (ver. 2.4-1): The Comprehensive R Archive Network web page, accessed December 12, 2016, at https://cran.r-project.org/web/packages/vegan/index.html.

Ostenaa, D.A., Schimschal, U.S., King, C.E., Jr., Wright, J.W., Furgerson, R.B., Harrel, H.C., and Throner, R.H., 1993, Big Chino Valley groundwater study - Geologic framework investigations: Bureau of Reclamation Seismotectonic Report 93-2, $31 \mathrm{p}$.

Owen-Joyce, S.J., and Bell, C.K., 1983, Appraisal of water resources in the Upper Verde River area, Yavapai and Coconino Counties, Arizona: Arizona Department of Water Resources Bulletin 2, $219 \mathrm{p}$.

Parkhurst, D.L., and Charlton, S.R., 2008, NetpathXL—An Excel interface to the program NETPATH: U.S. Geological Survey Techniques and Methods, book 6, chap. A26, 11 p. [Also available at https://doi.org/10.3133/tm6A26.]

Patton, C.J., and Kryskalla, J.R., 2011, Colorimetric determination of nitrate plus nitrite in water by enzymatic reduction, automated discrete analyzer methods: U.S. Geological Survey Techniques and Methods, book 5, chap. B8, 34 p. [Also available at https://doi.org/10.3133/tm5B8.]

Pearthree, P.A., and Ferguson, C.A., 2012, Geologic map of the Wineglass Ranch 7 1/2' Quadrangle, Yavapai County, Arizona (ver. 1.0): Arizona Geological Survey Digital Geologic Map DGM-90, 1 sheet, scale 1:24,000.

Pierce, W.H., 1985, Arizona's backbone- the transition zone: Arizona Bureau of Geology and Mineral Technology Fieldnotes, v. 15, no. 3, 6 p.
Piper, A.M., 1944, A graphic procedure in the geochemical interpretation of water-analyses: Transactions - American Geophysical Union, v. 25, no. 6, p. 914-928. [Also available at https://doi.org/10.1029/TR025i006p00914.]

Plummer, L.N., Bexfield, L.M., Anderholm, S.K., Sanford, W.E., and Busenberg, E., 2012, Geochemical characterization of ground-water flow in the Santa Fe group aquifer system, Middle Rio Grande Basin, New Mexico (ver. 1.2): U.S. Geological Survey Water-Resources Investigations Report 03-4131, 395 p. [Also available at https://doi.org/ 10.3133/wri034131.]

Pohlert, T., 2020, Package 'trend'-Non-parametric trend tests and change-point detection (ver. 1.1.2): The Comprehensive R Archive Network web page, accessed January 13, 2020, at https://cran.r-project.org/web/ packages/trend/trend.pdf.

R Core Team, 2020, R-A language and environment for statistical computing: The R Project for Statistical Computing, Version 3.4.3, Vienna, Austria, accessed January 13, 2020, at https://www.R-project.org/.

Révész, K., and Coplen, T.B., 2008a, Determination of the $\delta^{2} \mathrm{H} /{ }^{1} \mathrm{H}$, of water-RSIL lab code 1574: U.S. Geological Survey Techniques and Methods, book 10, chap. C1, 27 p., accessed January 13, 2020, at https://doi.org/10.3133/ tm10C1.

Révész, K., and Coplen, T.B., 2008b, Determination of the $\delta^{18} \mathrm{O} / 16 \mathrm{O}$ of water-RSIL lab code 489 : U.S. Geological Survey Techniques and Methods, book 10, chap. C2, 28 p., accessed January 13, 2020, at https://doi.org/10.3133/ tm10C2.

Rothman, D.W., and Mays, L.W., 2014, Water resources sustainability-Development of a multi-objective optimization model: Journal of Water Resources Planning and Management, v. 140, no. 12, 9 p.

Schwab, K.J., 1995, Maps showing ground-water conditions in the Big Chino sub-valley of the Verde River Valley, Coconino and Yavapai Counties, Arizona, 1992: Arizona Department of Water Resources Hydrologic Map Series Report 28, 1 sheet, scale 1:250,000.

Shoemaker, E.M., Squires, R.L., and Abrams, M.J., 1974, The Bright Angel and Mesa Butte Fault Systems of northern Arizona, in Karlstrom, T.N.V, Swann, G.A., and Eastwood, R.L., eds., Geology of northern Arizona, with notes on archaeology and paleoclimate, part 1regional studies: Geological Society of America, Rocky Mountain Section, 27th Annual Meeting, Flagstaff, Ariz., p. 355-391. 
Thorstenson, D.J., and Beard, L.S., 1998, Geology and fracture analysis of Camp Navajo, Arizona Army National Guard, Arizona: U.S. Geological Survey Open-File Report 98-242, 42 p.

U.S. Environmental Protection Agency, 2019a, Drinking water contaminants: U.S. Environmental Protection Agency database, accessed June 14, 2019, at https://www.epa.gov/ ground-water-and-drinking-water/national-primarydrinking-water-regulations.

U.S. Environmental Protection Agency, 2019b, National recommended water quality criteria-Aquatic life criteria table: U.S. Environmental Protection Agency database, accessed June 14, 2019, at https://www.epa.gov/wqc/ national-recommended-water-quality-criteria-aquatic-lifecriteria-table.

U.S. Geological Survey, variously dated, National field manual for the collection of water-quality data: U.S. Geological Survey Techniques and Methods, book 9, chap. A1-A10, accessed February 21, 2019, at https://water.usgs.gov/owq/ FieldManual/.

U.S. Geological Survey, 2019, USGS water data for the Nation: U.S. Geological Survey National Water Information System database, accessed March 7, 2019, at https://doi.org/ 10.5066/F7P55KJN.

U.S. Geological Survey and Arizona Geological Survey, 2018, Quaternary fault and fold database for the United States: U.S. Geological Survey website, accessed November 2018 at https://earthquake.usgs.gov/hazards/qfaults/.

Wallace, B.L., and Laney, R.L., 1976, Maps showing groundwater conditions in the lower Big Chino Valley and Williamson Valley areas, Yavapai and Coconino Counties, Arizona, 1975-76: U.S. Geological Survey Water Resources Investigations $76-87,2$ sheets.

Weiss, R.F., 1968, Piggyback sampler for dissolved gas studies on sealed water samples: Deep-Sea Research, v. 15, p. 695-699.

White, W.M., 2013, Geochemistry 1st ed.: Oxford, WileyBlackwell, 660 p.
Wirt, L., 2005, Sources of base flow in upper Verde River, chap. F of Wirt, L., DeWitt, E., and Langenheim, V.E., eds., Geologic framework of aquifer units and ground-water flowpaths, Verde River headwaters, north-central Arizona: U.S. Geological Survey Open-File Report 2004-1411, 34 p.

Wirt, L., and DeWitt, E., 2005, Geochemistry of major aquifers and springs, chap. E of Wirt, L., DeWitt, E., and Langenheim, V.E., eds., Geologic framework of aquifer units and ground-water flowpaths, Verde River headwaters, north-central Arizona: U.S. Geological Survey Open-File Report 2004-1411, 30 p.

Wirt, L., DeWitt, E., and Langenheim, V.E., eds., 2005a, Geologic framework of aquifer units and ground-water flowpaths, Verde River headwaters, north-central Arizona: U.S. Geological Survey Open-File Report 2004-1411, variously paged.

Wirt, L., DeWitt, E., and Langenheim, V.E., 2005b, Hydrogeologic framework, chap. D of Wirt, L., DeWitt, E., and Langenheim, V.E., eds., Geologic framework of aquifer units and ground-water flowpaths, Verde River headwaters, north-central Arizona: U.S. Geological Survey Open-File Report 2004-1411, 27 p.

Wirt, L., DeWitt, E., and Langenheim, V.E., 2005c, Appendix A. Water chemistry data for wells and springs (1981 to 2003), Verde River headwaters region, Arizona, and Appendix B. Isotope data for wells and springs (1986 to 2003), Verde River headwaters, Arizona of Wirt, L., DeWitt, E., and Langenheim, V.E., eds., Geologic framework of aquifer units and ground-water flowpaths, Verde River headwaters, north-central Arizona: U.S. Geological Survey Open-File Report 2004-1411, 27 p.

Wirt, L., and Hjalmarson, H.W., 2000, Sources of springs supplying base flow to the Verde River headwaters, Yavapai County, Arizona: U.S. Geological Survey Open-File Report 99-0378, $50 \mathrm{p}$.

Zuber, A., Weise, S.M., Osenbruck, K., Grabczak, J., and Ciezkowski, W., 1995, Age and recharge area of thermal waters in Ladek Spa (Sudeten, Poland) deduced from environmental isotope and noble gas data: Journal of Hydrology (Amsterdam), v. 167, no. 1-4, p. 327-349. [Also available at https://doi.org/10.1016/0022-1694(94)02587-2.] 



\section{Appendix 1. Groundwater Geochemistry Data for Samples Collected by the U.S. Geological Survey from the Big Chino Subbasin Between 2011 and 2018}

Appendix 1 is available as an Excel table and commaseparated value (.csv) file, both of which may be downloaded at https://doi.org/10.3133/sir20205094. The data in this appendix also are available from the U.S. Geological Survey
(USGS) National Water Information System database (U.S. Geological Survey, 2019; https://doi.org/10.5066/F7P55KJN) using the 15-digit numbers listed in the "USGS site number" column in appendix 1 . 

For additional information, contact:

Director, New Mexico Water Science Center U.S. Geological Survey

6700 Edith Blvd NE

Albuquerque, New Mexico 87113

For additional information, visit https://www.usgs.gov/centers/nm-water

Publishing support provided by Lafayette Publishing Service Center 


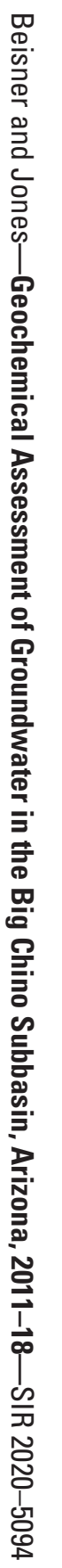

